St. Vincent and the Grenadines: 2018 Article IV Consultation-Press Release; Staff Report and Statement by the Executive Director for St. Vincent and the Grenadines 


\section{INTERNATIONAL MONETARY FUND}

February 2019

\section{ST. VINCENT AND THE GRENADINES \\ 2018 ARTICLE IV CONSULTATION—PRESS RELEASE, STAFF REPORT AND STATEMENT BY THE EXECUTIVE DIRECTOR FOR ST. VINCENT AND THE GRENADINES}

Under Article IV of the IMF's Articles of Agreement, the IMF holds bilateral discussions with members, usually every year. In the context of the 2018 Article IV Consultation with St. Vincent and the Grenadines, the following documents have been released and are included in this package:

- A Press Release summarizing the views of the Executive Board as expressed during its February 15, 2019 consideration of the staff report that concluded the Article IV Consultation with St. Vincent and the Grenadines.

- The Staff Report prepared by a staff team of the IMF for the Executive Board's consideration on February 15, 2019, following discussions that ended on November 15, 2018, with the officials of St. Vincent and the Grenadines on economic developments and policies. Based on information available at the time of these discussions, the staff report was completed on January 24, 2019.

- An Informational Annex prepared by the IMF staff.

- A Debt Sustainability Analysis prepared by the staff of the IMF and the International Development Association (IDA).

- A Staff Supplement updating information on recent developments.

- A Statement by the Executive Director for St. Vincent and the Grenadines.

The IMF's transparency policy allows for the deletion of market-sensitive information and premature disclosure of the authorities' policy intentions in published staff reports and other documents.

Copies of this report are available to the public from

International Monetary Fund $\bullet$ Publication Services

PO Box 92780 - Washington, D.C. 20090

Telephone: (202) 623-7430 • Fax: (202) 623-7201

E-mail: publications@imf.org Web: http://www.imf.org

Price: $\$ 18.00$ per printed copy

\section{International Monetary Fund Washington, D.C.}


Press Release No. 19/58

FOR IMMEDIATE RELEASE

February 25, 2019
International Monetary Fund

$70019^{\text {th }}$ Street, NW

Washington, D. C. 20431 USA

\section{IMF Executive Board Concludes 2018 Article IV Consultation with St. Vincent and the Grenadines}

On February 15, 2019, the Executive Board of the International Monetary Fund (IMF) concluded the Article IV consultation ${ }^{1}$ with St. Vincent and the Grenadines. The 2018 Article IV consultation focused on policies to achieve stronger and sustainable growth, build fiscal buffers, bolster resilience to natural disasters, and ensure financial stability

The economy of St. Vincent and the Grenadines has been recovering. The closure of Buccament Bay Resort (the largest hotel on the main island) and heavy rains with flooding and landslides slowed down growth in the second half of 2016 and early 2017. Following the opening of the new airport, however, tourist arrivals have recovered, boosting tourism-related services (such as hotels, restaurants, and retail). Increased demand for reconstruction materials from Dominica (struck by Hurricane Maria in September 2017) also helped the recovery. As a result, quarterly data show that output growth (year-on-year) has turned positive since the third quarter of 2017. Over the past year, inflation has remained around 2-3 percent.

The growth outlook is positive. Staff expects real GDP growth to rebound from 0.7 percent in 2017 to 2 percent in 2018, and further to 2.3 percent in 2019, driven by increases in tourist arrivals, tourism-related activities (including investment in hotels and resorts), and related local production. Beyond 2020, growth would be sustained at around 2.3 percent, assuming steady tourism and investment growth.

This outlook is subject to both external and domestic risks. External risks include weakerthan-expected global growth, tighter global financial conditions, and higher oil prices.

\footnotetext{
${ }^{1}$ Under Article IV of the IMF's Articles of Agreement, the IMF holds bilateral discussions with members, usually every year. A staff team visits the country, collects economic and financial information, and discusses with officials the country's economic developments and policies. On return to headquarters, the staff prepares a report, which forms the basis for discussion by the Executive Board.
} 
Domestic risks include more severe and frequent natural disasters, the loss of correspondent banking relationships, and materialization of financial sector risks. There is also upside potential stemming from stronger-than-expected tourist arrivals, investor interest, concessional financing for capital projects, and the successful completion of the geothermal power plant.

\section{Executive Board Assessment ${ }^{2}$}

Executive Directors commended the authorities for successfully reinvigorating the St. Vincent and the Grenadines' economy. Nonetheless, they noted the continuing challenges in terms of making economic growth more sustainable, reducing public debt, and increasing resilience to natural disasters.

Directors stressed the importance of advancing structural reforms to raise longer-term growth. They urged the authorities to capitalize on the growth opportunities created by the new airport. They recommended vigorously implementing policies to foster private sector activity, by improving the investment climate and strengthening human and physical capital, including investing in climate-resilient infrastructure.

Directors emphasized the importance of bolstering fiscal buffers. They welcomed the authorities' commitment to meeting the 60 percent of GDP debt target by 2030 and underscored the need for fiscal consolidation that does not jeopardize economic growth. They recommended prioritizing capital projects taking into account capacity and budget constraints and seeking concessional financing. Directors also encouraged taking additional fiscal measures, including broadening the tax base and reforming the pension system.

Directors welcomed the establishment of the Contingency Fund as an important instrument to protect public finances from the impact of natural disasters and climate change. They underscored the need to legislate the Contingency Fund's governance and operational framework to ensure its effectiveness and transparency. Directors also suggested expanding the coverage of disaster insurance, especially against floods. More generally, they recommended continuing to strengthen disaster preparedness, including reviewing the National Emergency and Disaster Act, updating river basin flood risk maps, and enhancing public education and awareness.

Directors encouraged the authorities to strengthen the institutional fiscal framework. Priorities include adopting a medium-term fiscal framework, strengthening revenue administration by moving toward a risk-based approach and completing the various reform

\footnotetext{
${ }^{2}$ At the conclusion of the discussion, the Managing Director, as Chairman of the Board, summarizes the views of Executive Directors, and this summary is transmitted to the country's authorities. An explanation of any qualifiers used in summings up can be found here: http://www.imf.org/external $/ \mathrm{np} / \mathrm{sec} / \mathrm{misc} /$ qualifiers.htm.
} 
initiatives, issuing regulations to strengthen the oversight of state-owned enterprises, and establishing a legal and institutional framework to assess potential risks from public-private partnerships.

Directors highlighted the need to further strengthen financial sector oversight. They urged the authorities to enact pending legislation to strengthen the Financial Services Authority's enforcement power. Directors urged the authorities to move ahead with preparing a crisis management plan for the non-bank financial sector and setting up a Financial Crisis Management Committee, building on earlier technical assistance provided by CARTAC.

Directors commended progress in addressing remaining legal deficiencies in the AML/CFT framework. Going forward, they recommended focusing on ensuring the effectiveness of AML/CFT preventative measures and completing the National Risk Assessment. 


\begin{tabular}{|c|c|c|c|c|c|c|c|}
\hline \multicolumn{8}{|c|}{ St. Vincent and the Grenadines: Social and Demographic Indicators 2014-2019 } \\
\hline $\operatorname{Area}(\mathrm{sq} . \mathrm{km})$ & 389.3 & \multicolumn{5}{|c|}{ Adult literacy rate (percent, 2001) } & 89.0 \\
\hline Population (2016) & & \multicolumn{5}{|c|}{ Health and nutrition } & \\
\hline Total (thousands) & 109.6 & \multicolumn{5}{|c|}{ Calorie intake (per capita a day, 2007) } & 2,810 \\
\hline Rate of growth (percent per year) & 0.09 & \multicolumn{5}{|c|}{ Population per physician (per thousand, 2004) } & 1.2 \\
\hline Density (per sq. km.) & 281.5 & \multicolumn{5}{|c|}{ Health expenditure per capita (PPP-2011, 2004) } & 917 \\
\hline Population characteristics & & \multicolumn{5}{|c|}{ Gross domestic product (2016) } & \\
\hline Life expectancy at birth (years, 2016) & 73.0 & \multicolumn{5}{|c|}{ (millions of US dollars) } & 771 \\
\hline Infant mortality (per thousand live births, 2016) & 15.2 & \multicolumn{5}{|c|}{ (millions of EC dollars) } & 2,081 \\
\hline Under 5 mortality rate (per thousand, 2016) & 17.0 & \multicolumn{5}{|c|}{ (US\$ per capita) } & 7,000 \\
\hline & & \multirow[t]{2}{*}{2014} & \multirow[t]{2}{*}{2015} & \multirow[t]{2}{*}{2016} & \multirow[t]{2}{*}{2017} & 2018 & 2019 \\
\hline & & & & & & \multicolumn{2}{|c|}{ Proj. } \\
\hline & & \multicolumn{6}{|c|}{ (Annual percentage change, unless otherwise specified) } \\
\hline \multicolumn{8}{|l|}{ Output and prices } \\
\hline Real GDP (factor cost) & & 0.2 & 0.8 & 0.8 & 0.7 & 2.0 & 2.3 \\
\hline Real GDP (market prices) & & 1.2 & 1.3 & 2.0 & 0.9 & 2.0 & 2.3 \\
\hline Nominal GDP (market prices) & & 0.9 & 3.8 & 2.0 & 1.9 & 5.2 & 4.6 \\
\hline Consumer prices, end of period & & 0.1 & -2.1 & 1.0 & 3.0 & 2.0 & 2.0 \\
\hline Consumer prices, period average & & 0.2 & -1.7 & -0.2 & 2.2 & 2.4 & 2.0 \\
\hline \multicolumn{8}{|l|}{ Banking system $1 /$} \\
\hline Net foreign assets & & 1.1 & 1.7 & 8.8 & -2.6 & -0.9 & 3.4 \\
\hline Net domestic assets & & 8.4 & 12.0 & -14.3 & 3.8 & 1.9 & 1.8 \\
\hline Credit to private sector & & -0.2 & 1.7 & 1.0 & 1.1 & -0.1 & 1.3 \\
\hline \multicolumn{8}{|l|}{ Central government finances (in percent of GDP) } \\
\hline Total revenue & & 29.3 & 27.9 & 29.8 & 30.3 & 27.8 & 28.2 \\
\hline Tax revenue & & 24.0 & 23.6 & 25.5 & 25.7 & 24.1 & 24.4 \\
\hline Grants & & 2.0 & 1.2 & 1.2 & 2.1 & 1.4 & 1.4 \\
\hline Total expenditure and net lending & & 32.3 & 30.0 & 28.7 & 30.8 & 29.8 & 29.9 \\
\hline Current expenditure & & 25.9 & 25.1 & 24.9 & 26.7 & 26.2 & 26.0 \\
\hline Wages and salaries & & 12.6 & 12.6 & 13.2 & 13.3 & 12.8 & 12.7 \\
\hline Interest & & 2.3 & 2.2 & 2.1 & 2.3 & 2.6 & 2.4 \\
\hline Capital expenditure & & 6.4 & 4.9 & 3.8 & 4.1 & 3.6 & 3.9 \\
\hline Overall balance & & -3.0 & -2.1 & 1.1 & -0.5 & -2.0 & -1.7 \\
\hline Overall balance (excl. grants) & & -5.0 & -3.3 & -0.1 & -2.6 & -3.4 & -3.1 \\
\hline Primary balance & & -0.7 & 0.1 & 3.2 & 1.9 & 0.6 & 0.8 \\
\hline Primary balance (excl. grants) & & -2.7 & -1.1 & 1.9 & -0.2 & -0.8 & -0.6 \\
\hline \multicolumn{8}{|l|}{ External sector (in percent of GDP) } \\
\hline External current account & & -25.8 & -14.5 & -15.2 & -17.2 & -15.9 & -15.0 \\
\hline Exports of goods and services & & 35.2 & 37.4 & 37.9 & 36.0 & 37.2 & 37.9 \\
\hline Imports of goods and services & & 61.1 & 54.5 & 55.7 & 54.3 & 55.0 & 54.0 \\
\hline Public sector external debt (end of period) & & 45.5 & 46.4 & 56.7 & 47.4 & 44.8 & 45.0 \\
\hline \multicolumn{8}{|l|}{ External public debt service } \\
\hline (In percent of exports of goods and services) & & 12.6 & 10.3 & 27.7 & 51.0 & 28.4 & 15.2 \\
\hline \multicolumn{8}{|l|}{ Memorandum items } \\
\hline Gross public sector debt (in percent of GDP) 2/ & & 79.4 & 79.4 & 82.8 & 74.2 & 73.1 & 71.4 \\
\hline Nominal GDP (market prices; in millions of EC\$) & & 1,965 & 2,040 & 2,081 & 2,120 & 2,231 & 2,334 \\
\hline $\begin{array}{l}\text { Sources: ECCB; Ministry of Finance and Planning; ar } \\
1 / \text { Annual changes relative to the stock of broad m } \\
2 \text { /From 2016, reflects additional debt contracted w } \\
\text { GDP in 2016). It includes debt of central governme }\end{array}$ & $\begin{array}{l}\text { IMF sta } \\
\text { ley at th } \\
\text { Petroc } \\
\text { and sta }\end{array}$ & $\begin{array}{l}\text { lates and pr } \\
\text { ning of the } \\
\text { ut not previ } \\
\text { d enterpris }\end{array}$ & $\begin{array}{l}\text { ctions. } \\
\text { iod. } \\
\text { sly reco }\end{array}$ & d (EC\$ 1 & million & 5.4 perc & t of \\
\hline
\end{tabular}




\section{INTERNATIONAL MONETARY FUND}

January 24, 2019

\section{ST. VINCENT AND THE GRENADINES}

\section{STAFF REPORT FOR THE 2018 ARTICLE IV CONSULTATION} KEY ISSUES

Context. Following the opening of a modern international airport, signs of an economic recovery have emerged, with increased direct flights from major cities in the U.S. and Canada and renewed interests from foreign investors in tourism projects. The overall fiscal balance has improved over the past few years, and the debt to GDP ratio fell in 2017 for the first time since 2007. Despite these positive developments, St. Vincent and the Grenadines faces challenges in sustaining the growth momentum over the longer-term. Like other Caribbean economies, its high exposure to natural disasters, limited land, narrow production and exports base, weak business competitiveness, and limited physical and human capital constrain potential growth. The financial system remains broadly stable but has vulnerable spots in the non-bank financial sector.

Focus of the consultation. The 2018 Article IV consultation focused on policies to achieve stronger and sustainable growth, build fiscal buffers, bolster resilience to natural disasters, and ensure financial stability.

\section{Main Policy Recommendations:}

- Implement structural reforms to foster private sector activity, by improving the investment environment and strengthening physical and human capital.

- Consider taking additional fiscal adjustment measures to increase buffers, by broadening the tax base and advancing pension reform. Adopt a medium-term fiscal framework, strengthen revenue administration, and improve the planning and execution of public infrastructure projects.

- $\quad$ Set up a governance and operational framework for the Contingency Fund for natural disasters and continue to work on strengthening disaster preparedness, including the development of a long-term plan for resilient infrastructure.

- Strengthen financial sector oversight, develop a crisis management framework, and complete the National Risk Assessment. 
Approved By Patricia Alonso-Gamo (WHD) and Johannes Wiegand (SPR)
Discussions took place in Kingstown during November 5-15, 2018. The team comprised K. Ishi (head), M. Rosales Torres, C. Castellanos Garcia, and J. Moeller (all WHD). Y. Li and M. El Kawkabi provided valuable assistance. C. Williams (OED) participated in the discussions. The mission met with Prime Minister Honorable R. Gonsalves; Finance Minister Honorable C. Gonsalves; regulators; senior government officials; labor unions representatives; opposition parties leaders; and representatives from the financial and business sector.

\section{CONTENTS}

CONTEXT

RECENT DEVELOPMENTS: RETURN TO GROWTH

OUTLOOK AND RISKS: CAUTIOUS OPTIMISM

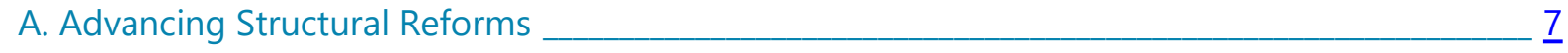

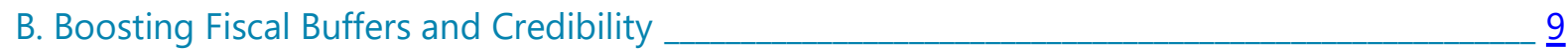

C. Strengthening Resilience to Natural Disasters Hazards and Climate Change________ 14

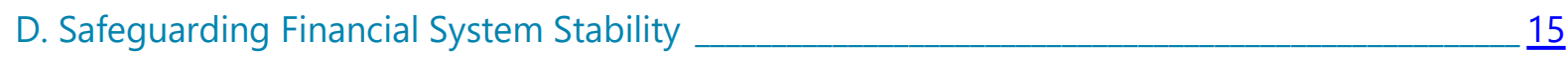

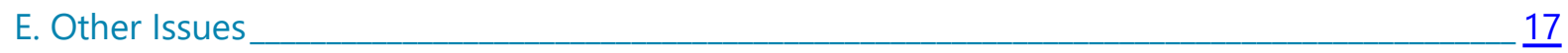

AUTHORITIES' VIEWS ________________________________________________

STAFF APPRAISAL

\section{BOXES}

1. Public Pension Systems

2. Budgetary Arrears and Classification Issue

\section{FIGURES}

1. Key Macroeconomic Indicators

2. Real Sector Developments

3. External Sector Developments 23

4. Fiscal Sector Developments $\underline{24}$

5. Financial Sector Developments 


\section{TABLES}

1. Selected Social and Economic Indicators, 2014-19

2. Balance of Payments Summary, 2014-23 (In millions of Eastern Caribbean Dollars)

3 Summary of Central Government Operations, 2014-2019 (In millions of Eastern Caribbean

Dollars)

4. Summary of Central Government Operations, 2014-2019 (In Percent of GDP)

5. Monetary Survey, 2014-2019

6. Baseline Scenario, Medium-Term Projections, 2014-2023

7. External and Financial Vulnerability Indicators, 2014-2017

\section{ANNEXES}

I. Implementation of Previous Key Staff Advice $\underline{33}$

II. External Stability Assessment and Competitiveness $\underline{35}$

III. Risk Assessment Matrix $\underline{38}$

\section{APPENDICES}

I. The New International Airport: Bid for Growth $\underline{39}$

II. Disaster Risk Financing Strategies And Contingency Fund $\underline{42}$ 


\section{CONTEXT}

1. More favorable outlook. The economy of St. Vincent and the Grenadines underperformed after the global financial crisis, with real GDP growth averaging only 0.6 percent in 2010-2017 (Figure 1). Public debt rose fast, due to the construction of the Argyle International Airport (more modern and resilient to natural disasters than the old one, see Appendix I), which started in 2008. Following the long-awaited opening of the airport in February 2017, however, signs have emerged that the economy has turned the corner, with increased direct flights from major cities in the U.S. and Canada and renewed interests in tourism projects by foreign investors. The economy has rebounded since mid-2017, while the debt to GDP ratio fell in 2017 for

Growth Outlook and Public Debt

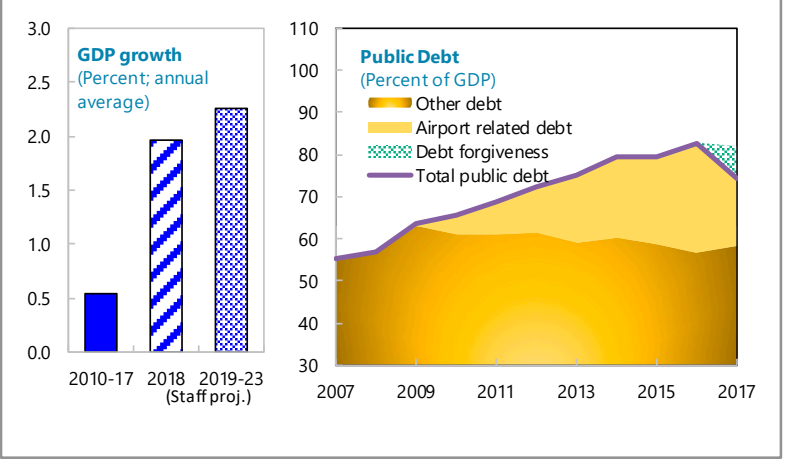
the first time since 2007.

2. St. Vincent and the Grenadines, however, continues to face challenges to sustain the growth momentum. It is a small island economy, with a population of about 110,000 and a GDP per capita of about US $\$ 7,100$. The economy is highly dependent on tourism-related activities, but the number of tourists is relatively modest compared to other economies in the Eastern Caribbean Currency Union (ECCU). Like other countries in the Caribbean, its high exposure to natural disasters, limited land, narrow production and exports base, shallow

\begin{tabular}{|c|c|c|c|c|}
\hline \multicolumn{5}{|c|}{ Eastern Caribbean Currency Union: Size of the Economies, 2017} \\
\hline & $\begin{array}{r}\text { Population } \\
\text { ('000) }\end{array}$ & $\begin{array}{r}\text { GDP } \\
\text { (US\$ mill) }\end{array}$ & $\begin{array}{l}\text { GDP per } \\
\text { capita } \\
\text { (US\$) }\end{array}$ & $\begin{array}{r}\text { Stay-over } \\
\text { visitors } \\
(\text { '000) }\end{array}$ \\
\hline \multicolumn{5}{|l|}{ Antigua and } \\
\hline Barbuda & 91.2 & 1,524 & 16,702 & 247.3 \\
\hline Dominica & 70.7 & 560 & 7,921 & 60.9 \\
\hline Grenada & 107.6 & 1,115 & 10,360 & 146.4 \\
\hline St. Kitts and Nevis & 56.9 & 928 & 16,296 & 113.7 \\
\hline St. Lucia & 175.5 & 1,686 & 9,607 & 386.1 \\
\hline \multicolumn{5}{|l|}{ St. Vincent and the } \\
\hline Grenadines & 110.2 & 801 & 7,271 & 76.0 \\
\hline
\end{tabular}
financial system, and limited physical and human capital constrain potential growth.

3. The authorities have made progress in addressing these challenges. Fiscal consolidation has advanced, a Contingencies Fund for natural disaster hazards was established in 2017, and legislative efforts are underway to strengthen the fiscal institutional framework and the financial system, broadly in line with staff recommendations from the last Article IV Consultation in December 2017 (Annex I). These reform efforts, however, have sometimes lagged, in part due to capacity constraints. Against this backdrop, the 2018 Article IV Consultation focused on policies to achieve stronger and sustainable growth, build fiscal buffers, bolster resilience to natural disasters, and ensure financial stability. 


\section{RECENT DEVELOPMENTS: RETURN TO GROWTH}

4. Output growth rebounded in mid-

2017. ${ }^{1}$ The closure of the Buccament Bay Resort (the largest hotel in the main island) and heavy rains which resulted in flooding and landslides slowed down growth in the second half of 2016 and early 2017. However, stayover visitors have since recovered, boosting tourism related private sector services.

Increased demand for reconstruction materials from Dominica (struck by Hurricane Maria in September 2017) also helped the economic recovery (Figure 2 and Table 1). Output growth (year on year) has turned positive since the second half of 2017.

\section{Inflation has remained around 2-3} percent over the past year. The inflation rate through mid-2018 was driven mostly by higher global commodity and fuel prices. The exchange rate peg as a member of the ECCU has provided an anchor for inflation. ${ }^{2}$

\section{The external position weakened}

slightly in 2017. Preliminary estimates by the Eastern Caribbean Central Bank (ECCB) suggest that the current account deficit widened from 15. 2 percent of GDP in 2016 to 17.2 percent of GDP in 2017, largely reflecting lower travel receipts and net private transfer inflows and higher net income payments (Figure 3 and Table 2). FDI inflows were the primary source of financing. The real effective exchange rate has appreciated about $5 \frac{1}{2}$ percent since the beginning of 2018 , due to the U.S. dollar strengthening. All three EBA-lite models suggest that the external position is weaker than the level consistent with fundamentals and desirable policies (Annex II).

\footnotetext{
${ }^{1}$ Unless otherwise indicated, GDP at factor prices (the authorities' preferred GDP measure for economic policy planning purposes) is used to discuss output growth.

2 St. Vincent and the Grenadines is a member of the ECCU, with a common central bank (the Eastern Caribbean Central Bank) and a currency (the Eastern Caribbean dollar). Since July 1976, the Eastern Caribbean dollar has been pegged to the U.S. dollar at EC\$2.70 per U.S. dollar.
} 
7. The fiscal position improved in recent years. The overall balance averaged a surplus of $1 / 4$ percent of GDP in 2016-2017, compared to a deficit of 3.4 percent of GDP in 2009-2015 (Figure 4 and Tables 3 and 4). The improved fiscal balance reflects, in part, efforts to mobilize revenue and contain current expense (mostly, wages and transfers), but also reduced interest expense (due to lower interest rates) and capital expense (in part due to the completion of the airport construction). Including two rounds of debt forgiveness with Venezuela last year ( $73 / 4$ percent of GDP), the

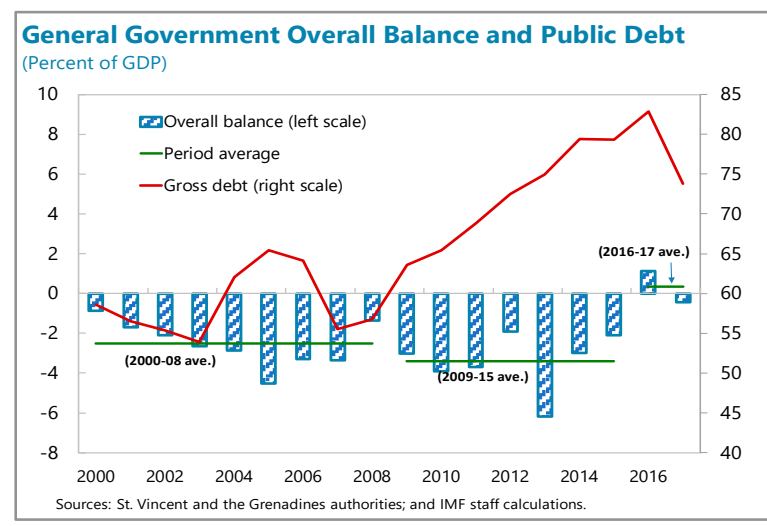
debt to GDP ratio fell to below 75 percent of GDP at end-2017.

8. Lending by credit unions is growing fast. Their lending to the private sector has increased by over 60 percent since 2010, albeit from a low level (total loans of credit unions were below 15 percent of GDP in 2017). In contrast, banks' credit activity has remained weak, partly because some foreign banks have downsized their operations in recent years (Figure 5 and Table 5).
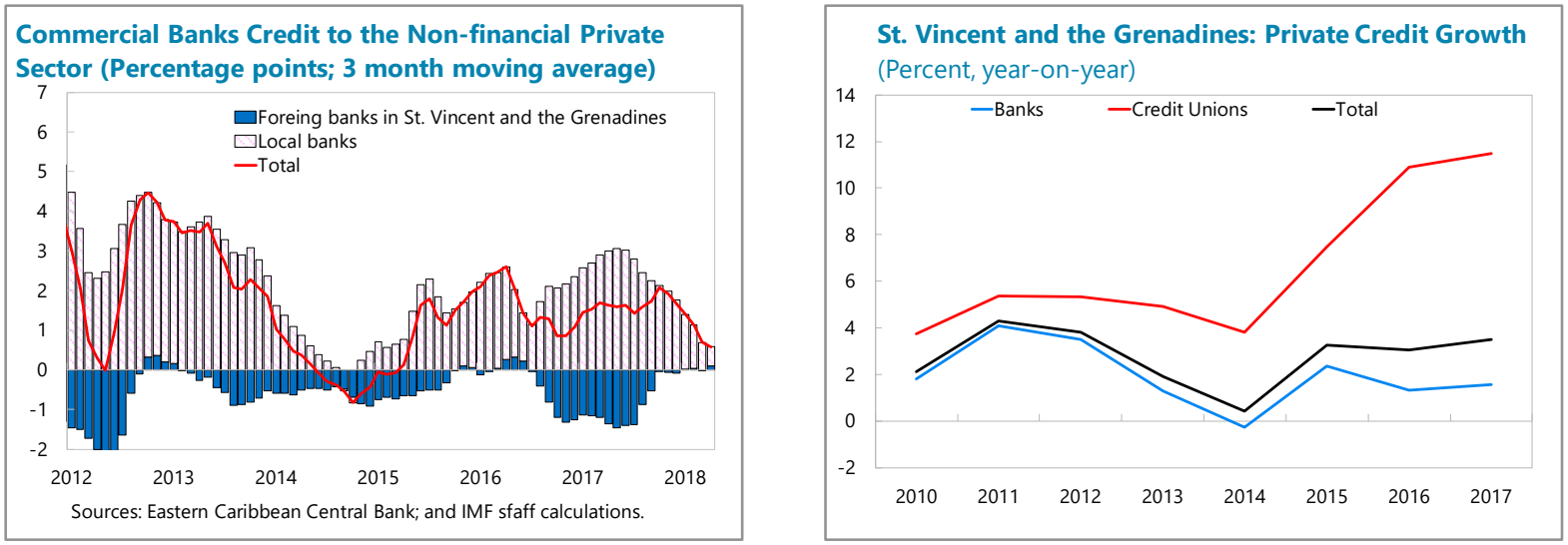

\section{OUTLOOK AND RISKS: CAUTIOUS OPTIMISM}

9. Growth momentum is positive. Real GDP growth is expected to rebound from 0.7 percent in 2017 to 2 percent in 2018, and further to 2.3 percent in 2019 (Table 6). Over the medium-term, growth would be sustained at 2.3 percent. ${ }^{3}$ Inflation is projected to stay stable at around 2 percent (broadly in line with inflation in the United States). Staff's growth projections assume the following:

\footnotetext{
${ }^{3}$ The medium-term growth projections have been revised down from the 2.8-3 percent growth assumed in the 2017 Article IV Staff Report. This reflects downward revisions to the annual average growth rate of real public capital spending (from 3 percent to 2.4 percent) and net FDI inflows (from 4.2 percent to 3.6 percent), as ongoing negotiations on large infrastructure, hotel, and resort projects would likely take more time than previously expected.
} 
- The new airport will boost stay-over tourist arrivals and tourism-related activities (including hotel and resort developments). Production of local products would also be boosted, with the increased capacity of air cargo.

- Non-traditional crops (e.g., cocoa, and dasheen) and fisheries (e.g., lobsters and tuna) are expected to pick up gradually, reflecting the authorities' efforts to promote agribusiness by attracting foreign investors and supporting local entrepreneurs.

- Construction activity would be boosted by new hotel and resort developments. In addition, public capital investments are expected to gradually rise, including projects to mitigate natural disaster hazards.

- The current account deficit is projected to narrow gradually, as tourism receipts increase, and agriculture and fishery exports take off.

10. Risks to the medium term are tilted to the downside (Table 7 and Risk Assessment Matrix in Annex II).

- External risks include weaker than expected global growth. In particular, slowdowns in the U.S. (accounting for about 30 percent of total tourist arrivals) and Canada (about 12 percent) could considerably affect the tourism sector. A tightening of global financial conditions would lead to higher funding costs.

- Domestic risks include more severe and frequent natural disasters. St. Vincent and the Grenadines is exposed to high levels of meteorological (e.g., high wind, excess rainfall, and hurricane) hazards. These natural disaster risks can be exacerbated by climate change, resulting in infrastructure damage and disruption of economic activity. As a tail risk scenario, financial sector risks could also materialize, given that some financial institutions hold high nonperforming loans (NPLs). The loss of correspondent banking relations (CBRs) could also impact economic activity.

- There is also upside potential to the medium-term outlook. Investor interest could be stronger than expected, resulting in more hotel and resort developments and investment in non-tourism sectors.

\section{POLICY DISCUSSIONS}

\section{A. Advancing Structural Reforms}

11. The timing is right for a renewed push on structural reforms to raise St. Vincent and the Grenadines' potential growth. As in many other regional economies, per capita GDP growth has dropped markedly since the global financial crisis, from 6.5 percent in 2001-08 to 2 percent in 2010-2017. The government has accomplished a major upgrade to the airport infrastructure, and its economic benefits are already visible with the increased number of tourists. For its benefits to reach 
broader economic sectors beyond tourism, the authorities need to foster private sector activity, by improving the investment environment and strengthening physical and human capital.

\section{The investment and business} environment can be strengthened further.

- The procedural and legislative requirements for investment-currently provided in several laws across different sectors-should be clearly

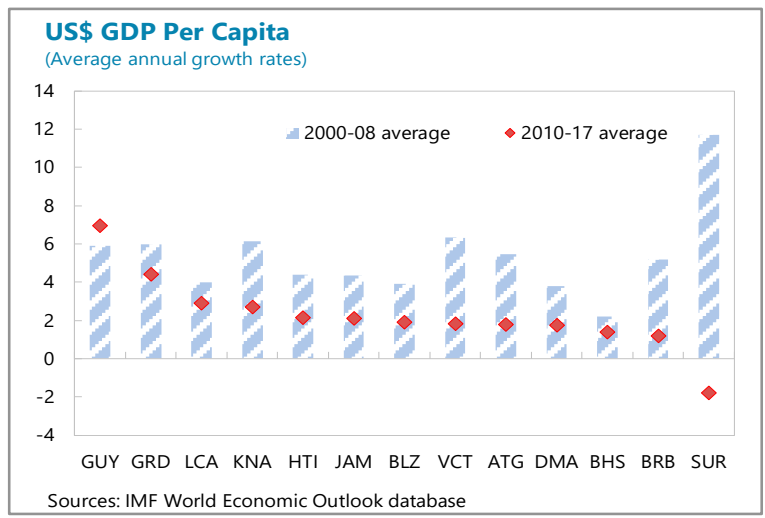
established in a standalone investment law, and Invest SVG (the government's investment promotion agency) should become a one-stop-shop to streamline investment procedures and reduce the administrative burden for potential investors. In addition, to further enhance transparency and protect fiscal revenues, tax incentives should be streamlined, and their scope for discretion be minimized.

- Efforts should continue to make economic infrastructure more resilient to natural disasters, particularly irrigation, water supply, roads, and ports. Developing a long-term infrastructure plan, in collaboration with key stakeholders, would help prioritize projects consistent with the government's strategic development goals (including building resilience), solicit donors' support, and boost investors' interest.

- There remains the perception that businesses face some difficulties to register property and access financing. ${ }^{4}$ The ECCU's regional initiative to establish a credit bureau and a collateral registration system would help facilitate credit activity.

\section{The government should continue efforts to improve productivity in the agriculture} and fishery sector. Some locally-grown products (such as fruits, vegetables) and some types of fish and seafood have the potential to be more competitive, and more can be exported or sourced to the domestic tourism sector. ${ }^{5}$ Farmers and fishers, however, face challenges in raising productivity and tapping markets abroad, in part due to poor access to markets, inadequate water supply and irrigation, and technological weaknesses. The government is participating in the Organization of Eastern Caribbean States Regional Agriculture Competitiveness Project, with technical support of the World Bank, aimed at raising agricultural competitiveness, including by enhancing value chains and marketing, and strengthening linkages between agriculture/fishery sectors and the tourism sector.

\footnotetext{
4 For example, the World Bank's 2019 Doing Business Survey shows that "registering property" and "getting credit" are ranked 171th and 161th position out of 190 economies. Note that the accuracy of these ranks can be biased by experts' views.

5 See Jansen et. al., 2015, "Linking farmers and Agro-processors to the Tourism Industry in the Eastern Caribbean," Report No. ACS16280, World Bank.
} 
14. Further actions are needed to develop human capital. Over the last decade, St. Vincent and the Grenadines has achieved universal secondary education. Despite this attainment, the unemployment rate remains persistently high, reflecting few employment opportunities provided by large companies but also labor skill mismatches. ${ }^{6}$ The authorities should continue efforts to address the labor skill problem by improving the labor market policies in place, including vocational education and training, apprenticeships, and job counseling. In this light, the effectiveness of the Technical and Vocational Education and Training (TVET) program should be periodically reviewed. In addition, containing increases in the minimum wage will remain important to improve competitiveness.

15. The construction of a geothermal project has begun. In June 2018, the government signed an agreement to develop a $10 \mathrm{MW}$ geothermal power plant with Canadian and Icelandic energy companies. A power purchase agreement with VINLEC (the domestic utility company) is expected to be signed soon. Once geothermal electricity production commences in 2021, St. Vincent and the Grenadines' dependence on imported fuels would be reduced, and electricity prices would become more predictable and cheaper over the medium term, enhancing productivity.

\section{B. Boosting Fiscal Buffers and Credibility}

\section{The fiscal position is expected to weaken} in 2018, albeit slightly. The 2018 budget envisaged a widening of the overall deficit to $61 / 2$ percent of GDP, primarily due to a significant increase in capital spending (more than doubled to $91 / 2$ percent of GDP). Preliminary data through the first nine months of 2018 suggest that revenue collection was weaker than the budget forecast, due to larger-thanexpected revenue losses from cuts in the corporate and personal income tax rates in the budget. Wellcontained current spending and lower-thanbudgeted capital spending, however, limited the deficit. Staff estimates the fiscal deficit for 2018 at 2 percent of GDP, about $4 \frac{1}{2} 2$ percentage points below the budget forecast.

17. The authorities stressed their commitment to bring the debt to GDP ratio down to the ECCU regional goal of 60 percent by 2030 . Gearing the fiscal policy to meet this target is important to ensure long-term fiscal sustainability and bolster budget credibility, especially given the high risk of debt distress (see Debt Sustainability Analysis report). The government's track record

\footnotetext{
${ }^{6}$ Government statistics estimated the unemployment rate at 25.8 percent in 2017 . There is, however, concern that this number overstates the current unemployment rate, as the survey that year included a large number of students coming back from studying abroad and seeking jobs. The Ministry of Finance estimates that the unemployment rate likely remains around 20 percent, broadly unchanged from the previous 2012 Census.
} 
suggests that although sizable deficits were projected over the past several years, reflecting mainly ambitious capital budgets, the government has actually managed to contain the overall deficit below 2 percent of GDP since 2015. Accordingly, together with the lower level of debt and the expected growth recovery, the staff's baseline debt sustainability analysis suggests that the 60 percent goal could be achieved by 2030 . Key assumptions in the staff's baseline scenario are as follows.

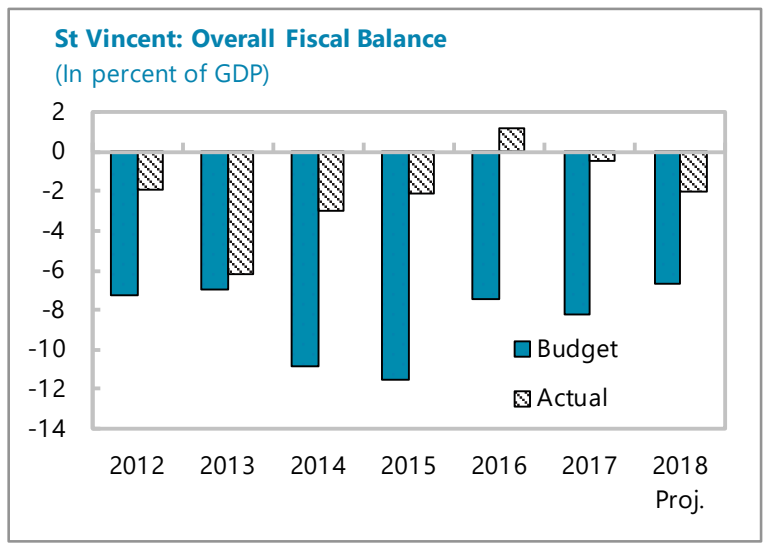

- The primary surplus position would improve from 0.6 percent of GDP in 2018 to around 1.1 percent of GDP over the medium term by containing the growth of the wage bill to around 3.5 percent (compared to the annual average growth rate of $31 / 4$ percent over the past decade), below nominal GDP growth.

- Expected fiscal costs of natural disasters are estimated at 1.4 percent of GDP a year (the average of the past 15 years), of which 0.7 percent of GDP could be covered by the contingency fund. The remaining balance could be covered through earmarked expenditure reserves to be included in the annual budget (see Section C).

\begin{tabular}{|c|c|c|c|c|c|c|}
\hline \multicolumn{4}{|c|}{ St. Vincent and the Grenadines: Baseline Policy Scenarios } & \multirow{2}{*}{\multicolumn{2}{|c|}{$\begin{array}{l}\text { Public Debt: Baseline Policy Scenarios }{ }^{1} \\
\text { (Percent of GDP) }\end{array}$}} & \multirow{3}{*}{100} \\
\hline & \multicolumn{3}{|c|}{ Baseline Policy Scenarios } & & & \\
\hline & $\begin{array}{l}\text { Baseline, ND } \\
\text { at historical } \\
\text { level }\end{array}$ & $\begin{array}{l}\text { Low growth, NDs } \\
\text { at historical level }\end{array}$ & $\begin{array}{l}\text { Low } \\
\text { growth, } \\
\text { severe ND }\end{array}$ & \multirow{2}{*}{80} & $\begin{array}{l}\text { —Baseline: NDs at historical levels } \\
\text { —Low growth, unchanged PB, NDs at historical levels }\end{array}$ & \\
\hline Real GDP growth (in percent) & 2.3 & 1.4 & 1.4 & & & \multirow{2}{*}{80} \\
\hline Primary balance (percent of GDP) & 1.1 & 1.1 & 0.6 & \multirow{3}{*}{60} & & \\
\hline Public sector debt (percent of GDP) & \multirow[t]{2}{*}{59} & \multirow[t]{2}{*}{67} & \multirow[t]{2}{*}{74} & & & \multirow[t]{2}{*}{60} \\
\hline \multirow{2}{*}{\multicolumn{5}{|c|}{$\begin{array}{l}\text { Natural disaster cost estimates } \\
\text { Gross fiscal costs }\end{array}$}} & & \\
\hline Gross fiscal costs & 1.4 & & & & & \multirow{5}{*}{$\begin{array}{l}\text { iDP. } \\
\text { of GDP. }\end{array}$} \\
\hline Withdrawal from Contingencies Fund/CCRIF & 0.7 & 0.7 & 0.7 & 40 & $201720182019202020212022 \quad 023 \quad 2024 \quad 025 \quad 2026 \quad 2027 \quad 2028 \quad 2029 \quad 2030 \quad 2031$ & \\
\hline Use of budget reserves & 0.7 & 0.7 & 0.7 & \multirow{3}{*}{\multicolumn{2}{|c|}{ 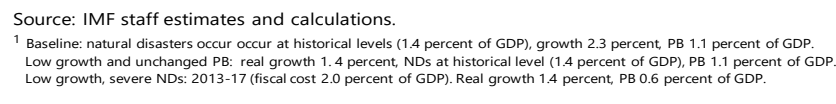 }} & \\
\hline Net fiscal costs & 0.0 & 0.0 & 0.6 & & & \\
\hline Source: IMF staff estimates and calculations. & & & & & & \\
\hline
\end{tabular}

\section{However, if downside risks were to materialize, the $\mathbf{6 0}$ percent target would not be} achievable by 2030. The most critical risks are: (i) low growth, and (II) more severe and frequent natural disasters.

- $\quad$ Lower growth risk scenario. If real GDP growth remains persistently low at 1.4 percent (comparable to the average growth rate over the last five years), the debt-to GDP ratio would only fall to around 67 percent of GDP by 2030. 
- $\quad$ More severe natural disasters scenario. This scenario assumes that natural disasters hit the country at the frequency and magnitude of the last 10 years (i.e. annual fiscal costs of 2 percent of GDP) and average real GDP growth is low at 1.4 percent (with more severe natural disasters, low growth becomes more likely). Annual fiscal costs would increase by 0.6 percent of GDP, which the government finances through issuing debt. Under this scenario, public debt would not fall and stay at around 72-75 percent of GDP.

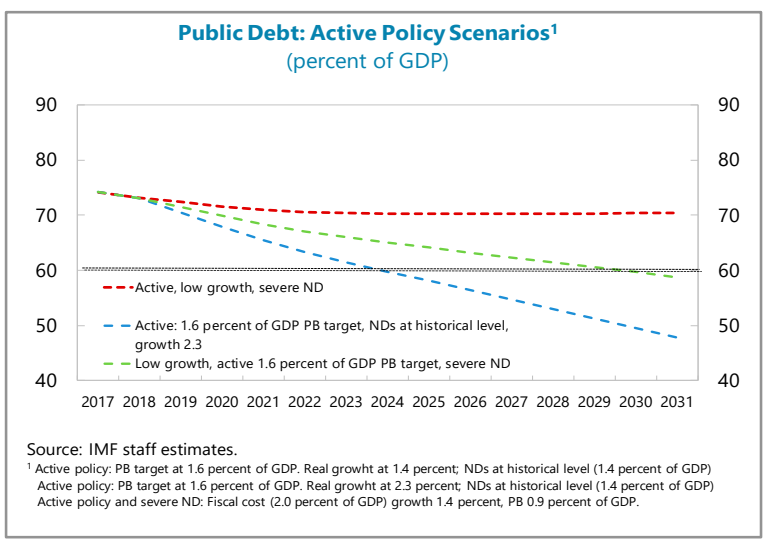

19. To guard against such risks, the authorities should consider undertaking a more active fiscal adjustment. Consideration should be given to balancing the need for building fiscal buffers and the feasibility of fiscal adjustment without creating an undue drag on growth, given that actual output would remain below its potential in the near term. Staff view an additional adjustment of $3 / 4$ percent of GDP as feasible, allowing an increase in the primary surplus to 1.6 percent of GDP within two years. Under these assumptions, public debt would fall to 60 percent of GDP by around 2030 even under the low-growth scenario, and the debt trajectory would remain stable even under the more severe natural disaster scenario.

\section{Both revenue and expenditure measures should be explored.}

- On the revenue side, the scope for raising taxes could be limited-for example, the standard VAT rate (16 percent) is among the highest in the Caribbean region. However, there is scope to broaden the tax base, including by (i) reducing exemptions on import duties and VAT on imports ${ }^{7}$; (ii) streamlining the list of VAT exemptions or zero-rated goods and services; (iii) replacing basic personal income tax exemptions by a tax credit; and (iv) reducing corporate income tax exemptions and updating depreciation scheduled.

- On the expenditure side, the growth of the wage bill could be limited to 2.5 percent a year (compared to 3.5 percent assumed in the baseline scenario), while the government vigorously proceeds with a long-standing pension reform

\begin{tabular}{|c|c|}
\hline \multicolumn{2}{|c|}{ Options for New Tax and Expenditure Measures } \\
\hline & $\begin{array}{r}\text { Percent of } \\
\text { GDP }\end{array}$ \\
\hline \multicolumn{2}{|l|}{ Tax measures } \\
\hline Reduce exemptions on import duties & 0.8 \\
\hline Reduce exemptions on VAT on imports & 0.5 \\
\hline $\begin{array}{l}\text { Streamline zero-rated and exempted goods } \\
\text { and services for domestic VAT }\end{array}$ & $\ldots$ \\
\hline Reform the corporate income tax structure $1 /$ & $\ldots$ \\
\hline Reform the personal income tax structure 2/ & 0.3 \\
\hline \multicolumn{2}{|l|}{ Expenditure Measures } \\
\hline $\begin{array}{l}\text { Contain wage bill by limiting wage increases } \\
\text { and retrenching and redeploying public sector } \\
\text { employees }\end{array}$ & 0.2 \\
\hline $\begin{array}{l}\text { Reform Public Service Pension System (PSPS) } \\
\text { and National Insurance Service (NIS) 3/ }\end{array}$ & 0.5 \\
\hline Total effects & 2.3 \\
\hline \multicolumn{2}{|l|}{ Source: IMF staff calculations. } \\
\hline \multicolumn{2}{|c|}{$\begin{array}{l}\text { 1/ Unify tax rates at the standard rate, reduce exemptions, update } \\
\text { the depreciation schedules, introduce thin-capitalization rules } \\
\text { and transfer pricing regulations). }\end{array}$} \\
\hline \multicolumn{2}{|l|}{ 2/ Replace the standard deduction with a tax credit. } \\
\hline $\begin{array}{l}\text { 3/ Parametric reforms aimed at reducing benefits for } \\
\text { reduce NIS' maximum pension and PSPS' accrual rate } \\
\text { introducing a new } 5 \text { percent contribution rate for PS } \\
\text { closing PSPS system to new entrants. }\end{array}$ & $\begin{array}{l}\text { hula (e.g., } \\
\text { and } \\
\text { S and }\end{array}$ \\
\hline
\end{tabular}

\footnotetext{
${ }^{7}$ Exemptions on import duties and VAT on imports were estimated at about 4 1/2 percent of GDP in 2017.
} 
plan (Box 1). Expenditure items that boost the economy's productive capacity and reduce the social gap—such as on education, job training, and infrastructure-should be protected or even enhanced.

\section{Box 1. Public Pension Systems}

There are two public pension systems in St. Vincent and the Grenadines. The contributory National Insurance Service (NIS) covers old-age benefits for public and private sector employees, self-employed, and voluntary contributors. The Public Sector Pension System (PSPS), which is non-contributory and funded through budget revenues, provides old-age benefits for civil servants.

The NIS system as currently designed is not sustainable. The NIS' financial position has deteriorated in recent years as its expenditure exceeds contribution income. The government reformed its parameters in 2014, including an increase in the contribution rate from 8 percent to 10 percent and an increase in the normal pensionable age from 60 to 65 over a period of 15 years. This reform improved the NIS' financial situation, but only temporarily, as its reserves are projected to be depleted by 2033.

The PSPS is viewed as too costly and generous. It supplements civil servants' NIS pension. Pensionable civil servants are entitled to receive up to two-thirds of their highest pensionable earnings. This means that adding the NIS, the maximum combined replacement rate is 126 percent. Budgetary contributions for the PSPS increased from 2.4 percent of GDP in 2014 to 2.8 percent in 2017.

\section{To support the effectiveness of fiscal policy and operations, efforts should continue to} strengthen revenue administration, the fiscal framework, and fiscal institutions and processes. Although the authorities are working on several reform initiatives, including the medium-term fiscal framework (MTFF), Tax Administration and Procedures Act (TAPA), and cash management, implementation has been rather slow.

- Revenue administration. To maximize the effective use of limited resources, the risk-based approach should be fully adopted. Especially, at customs, this would help facilitate timely customs clearance, thus enhancing trade, while allowing more resources to be allocated to highrisk traders. On internal revenue, the single Tax Identification Number (TIN) should be fully implemented, the tax registration database be kept up-to-date, while the Tax Administration and Procedures Act (TAPA) should be enacted promptly, which would help increase taxpayer compliance. Collaboration between the Inland Revenue Department and the Customs and Excises Department could be further enhanced. In the Inland Revenue Department, information management system should be upgraded, especially to support the risk management approach.

- MTFF. The Ministry of Finance (MOF) should submit a MTFF to parliament together with the 2019 budget and publish it. Meanwhile, efforts should continue to improve revenue forecasts and costing of key expenditure items. Going forward, staff encourage the authorities to consider introducing fiscal rules, which would help anchor the debt target, enhance the government's accountability, and thereby strengthen fiscal credibility. 
- Public infrastructure management. To improve infrastructure planning process and project selection, there are merits in developing a long-term national infrastructure plan, which should be linked closely to the MTFF. Projects should be prioritized based on the government's strategic development goals, the likelihood of successful implementation, and the certainty of project funding. The plan should also embed resilient infrastructure projects.

- Cash management. The recent establishment of a Cash Management System and a Cash Management Committee is welcome. Next steps should include preparing cash flow forecasts periodically. Separately, a full review of the stock of accounts payable should be conducted, aimed at setting apart long-standing accounts payable ("arrears") and developing a strategy to clear the stock of arrears (Box 2).

- State-owned enterprises (SOEs) and Public-Private Partnerships (PPPs). There remain significant weaknesses in oversight over SOEs, whose submission of financial reports is not always timely. To strengthen oversight over SOEs, the MOF is preparing regulations requiring all SOEs to submit timely financial and operational information to the MOF, and is also planning to establish a SOEs monitoring unit. In addition, the MOF should establish a framework to assess financial risks pertaining to PPPs, aimed at managing better the government's contingent liabilities.

\section{Box 2. Budgetary "Arrears" and Classification Issues}

Reported budgetary "accounts payable" fell from EC\$89 million (4.5 percent of GDP) at end-2014 to EC\$31 million (1.4 percent of GDP at end 2017. The reported figures include: (i) long-standing accounts payable to suppliers and contractors and (ii) other accounts payable such as funds in transit between government accounts (e.g., from the consolidated account to the sinking fund and the Contingencies Fund), invoices due on a future date, and over-budgeted expenses. The former can be considered as payment arrears.

Work is underway to ascertain the amount of payment arrears. The Accountant General Office is currently reviewing the stock of accounts payable to separate payment arrears from transitory accounts payable. The latter will be renamed as "Invoice Clearing Account" to better reflect the government's liabilities.

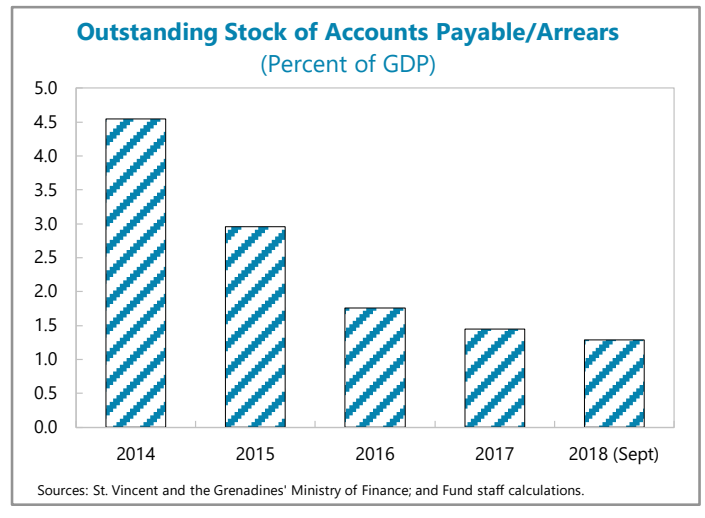

\begin{tabular}{|lr|}
\hline \multicolumn{2}{|c|}{$\begin{array}{r}\text { Stock of Accounts Payable, end-2017 } \\
\text { (Millions of EC dollars) }\end{array}$} \\
\hline \multicolumn{2}{|c|}{2017} \\
\hline Vendors & 10.7 \\
Subventions to SOEs & 5.7 \\
Contribution to local organizations & 0.4 \\
Contribution to foreign organizations & 5.9 \\
Contribution to Sinking and Contingency Fund & 2.9 \\
Utilities and others & 3.4 \\
Contracts & 0.6 \\
VAT arrears to Inland Revenue Dep. & 1.0 \\
Total & $\mathbf{3 0 . 7}$ \\
\hline \multirow{2}{*}{ Sources: St. Vincent and the Grenadines' Ministry of Finance. } \\
\hline
\end{tabular}




\section{Strengthening Resilience to Natural Disasters Hazards and Climate}

\section{Change}

\section{In recent years, although it has been spared catastrophic hurricanes, St. Vincent and} the Grenadines occasionally experienced heavy rains which led to flash flooding and landslides. Staff estimates that the annual economic damage of natural disasters is about 2 percent of GDP, based on St. Vincent and the Grenadine's historical experience over the last 15 years. Excluding the costs borne by the private sector (e.g., damages to housing), the expected fiscal costs are about 1.4 percent of GDP (see Appendix II).

\section{The establishment of the Contingency Fund constituted a significant step in} protecting public finances from natural disaster risks. To capitalize the fund, the authorities raised the standard VAT rate from 15 to 16 percent, and the VAT rate for tourism-related services from 10 to 11 percent in May 2017. They also introduced a climate resilience hotel levy (EC\$ 8 per room night) in October 2018. These measures are estimated to yield annual revenue of around 0.7 percent of GDP.

24. The Contingency Fund's governance and operational framework, however, needs to be legislated. Staff supports the authorities' intention to restrict the use of the Contingency Fund to costs associated with natural disasters. To assure its effectiveness, however, a specific legal framework should be established. Most importantly, the law should stipulate (i) the fund's investment policies; (ii) the procedure to appoint an independent operational manager; (iii) trigger, withdraws and replenishment procedures; and (iv) accountability and reporting requirements.

25. Additional fiscal buffers should be sought, in anticipation of natural disasters. There is significant uncertainty about the timing and expected costs of natural disasters. Besides, the size of the Contingency Fund is still small. Accordingly, additional fiscal buffers should be sought by expanding the coverage of disaster insurance to reduce the government's contingent liabilities, especially against floods. In addition, the budget framework needs some flexibility to accommodate unexpected expense in the event of a natural disaster, by setting aside expenditure reserves for emergency operations. Staff estimated that an annual expenditure reserve of about 0.7 percent of GDP would be sufficient to fill the gap between the expected annual fiscal costs (1.4 percent of GDP) and the contingency fund ( 0.7 percent of GDP).

26. Alongside, efforts should continue to strengthen disaster preparedness. A review of the National Emergency and Disaster Act of 2006 is encouraged to identify outdated provisions and update the law consistent with policy developments over the past decade. Other priorities include conducting a national risk assessment for natural disasters and updating river basin flood risk maps. Enhancing public education and awareness would be useful to improve compliance with the regulations on land use planning and the building code. Furthermore, a strategy to relocate communities facing threats from coastal erosion should also be developed. The National Emergency Management Office (NEMO) should be provided with resources for immediate emergency disaster response. 


\section{Safeguarding Financial System Stability}

\section{The financial system remains broadly stable but has vulnerable spots in the non-bank financial sector. ${ }^{8}$}

- Commercial banks' Tier 1 capital to risk weighted assets ratio was reported at 26.1 percent, well above the ECCB average, at end Q2 2018. The NPL ratio has fallen but is still high, above the ECCB's five percent benchmark. Profitability remains volatile, in part due to fluctuations of loan loss provisions pertaining to large borrowers, and the implementation of the new ECCB prudential standards on collateral valuation could lead to higher provisioning requirements and lower profitability.

\begin{tabular}{|c|c|c|c|c|c|c|}
\hline \multicolumn{7}{|c|}{$\begin{array}{l}\text { St. Vincent and the Grenadines and ECCU Banks: K } \\
\text { (Percent) }\end{array}$} \\
\hline & & 2014 & 2015 & 2016 & 2017 & 2018Q2 \\
\hline \multirow{2}{*}{ NPL / Total loans } & VCT & 10.0 & 8.7 & 9.5 & 8.2 & 6.8 \\
\hline & ECCU & 17.6 & 16.7 & 10.9 & 12.0 & 11.3 \\
\hline \multirow{2}{*}{ NPL net of provisions / Capital } & VCT & 52.7 & 42.5 & 44.6 & 38.2 & 30.7 \\
\hline & ECCU & 128.7 & 92.8 & 51.7 & 51.7 & 48.1 \\
\hline \multirow{2}{*}{ Liquid assets / current liabilities } & VCT & 42.2 & 42.9 & 44.7 & 41.7 & 39.9 \\
\hline & ECCU & 33.1 & 36.5 & 37.5 & 39.7 & 40.8 \\
\hline \multirow[t]{2}{*}{ Tier 1 capital / Risk-weighted assets } & VCT & 20.1 & 25.2 & 25.4 & 24.1 & 26.1 \\
\hline & ECCU & 10.8 & 13.4 & 15.4 & 16.3 & 15.8 \\
\hline \multirow{2}{*}{ Return on equity (annual average) 1/ } & VCT & -1.7 & 10.6 & 8.1 & -0.9 & 4.9 \\
\hline & ECCU & 4.0 & 20.3 & 19.5 & 13.2 & 12.6 \\
\hline \multirow{2}{*}{ Return on assets (annual average) 1/ } & VCT & -0.2 & 0.8 & 0.6 & -0.1 & 0.4 \\
\hline & ECCU & 0.2 & 0.8 & 0.9 & 0.8 & 0.8 \\
\hline \multirow{2}{*}{\multicolumn{7}{|c|}{ Source: Eastern Caribbean Central Bank }} \\
\hline $1 / \mathrm{H}$ & & & & & & \\
\hline
\end{tabular}

- Most of credit unions appear adequately capitalized, with a small amount of NPLs. However, rapid credit growth over the last few years, which in part reflects a shift of borrowers away from banks, raises concerns, especially because the credit unions' ability and resources to monitor and manage risks could be stretched. In addition, the implementation of IFRS 9 may raise their provisioning requirements and reduce their capital.

\begin{tabular}{|c|c|c|c|c|c|c|c|c|}
\hline \multicolumn{9}{|c|}{$\begin{array}{l}\text { Credit Unions: Selected Financial Indicators } \\
\text { (Percent) }\end{array}$} \\
\hline & \multicolumn{2}{|c|}{ GECCU } & \multicolumn{2}{|c|}{ TCCU } & \multicolumn{2}{|c|}{ KCCU } & \multicolumn{2}{|c|}{ PCCU } \\
\hline & 2016 & 2017 & 2016 & 2017 & 2016 & 2017 & 2016 & 2017 \\
\hline \multicolumn{9}{|l|}{ Capital } \\
\hline Equity-to-asset ratio $1 /$ & 13.5 & 14.1 & 16.0 & 16.0 & 11.7 & 11.8 & 9.7 & 7.5 \\
\hline \multicolumn{9}{|l|}{ Liquidity } \\
\hline Cash-to-asset ratio & 14.7 & 13.7 & 18.1 & 5.6 & 13.7 & 15.0 & 3.8 & 10.0 \\
\hline Deposit-to-loan ratio & 143.2 & 140.6 & 133.2 & 117.0 & 113.8 & 117.4 & 96.3 & 109.4 \\
\hline \multicolumn{9}{|l|}{ Profitability } \\
\hline Return on assets & 0.5 & 1.2 & -0.8 & 0.3 & 0.6 & 0.8 & 0.3 & -1.1 \\
\hline \multicolumn{9}{|l|}{ Loan portfolio composition } \\
\hline Share of mortgage loans & 41.9 & 43.6 & 67.0 & 60.9 & 62.7 & 61.3 & 16.0 & 14.7 \\
\hline Share of personal $\&$ consumer & 54.4 & 52.8 & 25.7 & 32.8 & 33.8 & 34.5 & 55.4 & 55.4 \\
\hline \multicolumn{9}{|l|}{$\begin{array}{l}\text { Non-performing loans } \\
\text { Imparred loans relative to }\end{array}$} \\
\hline $\begin{array}{l}\text { gross loans } \\
\text { Imparred and past due loans }\end{array}$ & 3.2 & 3.6 & 4.5 & 5.1 & 2.1 & 6.1 & 2.7 & 3.4 \\
\hline relative to gross loans & 5.4 & 7.8 & 4.5 & 5.1 & 3.1 & 7.7 & 7.1 & 7.3 \\
\hline \multicolumn{9}{|l|}{ Memoranda (in \$EC million) } \\
\hline Total assets & 210.4 & 231.9 & 113.6 & 112.0 & 91.8 & 98.8 & 12.5 & 14.9 \\
\hline Net income & 1.1 & 2.9 & -0.9 & 0.3 & 0.6 & 0.8 & 0.0 & -0.2 \\
\hline Impaired and past due loans & 6.8 & 11.0 & 2.9 & 3.8 & 2.1 & 5.2 & 0.6 & 0.7 \\
\hline Impairment allowance & -3.0 & -2.9 & -1.2 & -1.8 & -1.8 & -1.4 & -0.1 & -0.3 \\
\hline
\end{tabular}

\footnotetext{
${ }^{8}$ The domestic system is dominated by four commercial banks and two non-bank financial institutions, supervised by the ECCB; and four credit unions and one building and loan association, supervised by the Financial Services Authority. The total assets of the banking sector and the credit union sector are 110 percent of GDP and 30 percent of GDP (end-2017), respectively. The domestic system also involves several insurance firms, private pension plans, friendly societies and money services business, all supervised by the Financial Services Authority.
} 
28. The Financial Services Authority (FSA) has launched several new initiatives to strengthen its supervisory toolkit. Most notably, the FSA introduced stress testing as one of the core supervisory tools to assess financial strength of credit unions. The FSA is also planning to introduce stress testing exercises for insurance firms. Furthermore, reporting requirements of credit unions and other non-bank financial institutions have been expanded (to include, for example, more granularity on NPLs, provisioning, and lending distribution).

\section{The authorities, however, should continue efforts to strengthen the regulatory and} supervisory framework. Regional initiatives at the ECCU level, including the full operationalization of the Eastern Caribbean Asset Management Corporation and the enactment of the Harmonized Credit Union Regulations, would help reduce NPLs, strengthen financial sector oversight, and promote financial system soundness. For the authorities, the priorities are:

- Non-bank supervision. Intensified competition among financial institutions could lead to an erosion of lending standards, especially given the recent rapid increase in loans by credit unions. The FSA should continue to ensure that prudential standards, especially on collateral valuation and provisioning requirements, be fully enforced, and sound risk management practice be maintained. It should also maintain the enhanced supervision of the Building and Loan Association. Supervision of insurance firms can be further strengthened by enhancing groupwide supervision. The review of the adequacy of the FSA's budgetary resources is also encouraged.

- IFRS 9. The implementation of IFRS 9 may raise provisioning requirements of financial institutions and reduce their capital. Accordingly, the FSA should remain vigilant.

- Stress testing and financial stability assessment. Stress testing should be extended to (i) analyze multi-factor shock scenarios for credit unions, (ii) cover insurance firms, and (iii) incorporate interlinkages among various institutions in collaboration with the ECCB.

- Reporting and transparency. The FSA is encouraged to more periodically communicate its financial stability assessment to the public. This could take the form of providing a higher-level assessment of the health of the financial system, including financial soundness indicators of credit unions and other non-bank financial institutions.

\section{The authorities are encouraged to advance the ongoing reform initiatives in the}

financial sector. Several draft laws are still pending approval. Most importantly, the approval of the FSA regulations is key to help the FSA enforce prudential requirements, intervene promptly in problem institutions, and take corrective actions. Other pending bills include the amendments to the Building Societies Act and the Friendly Societies Act. In addition, building on technical assistance provided by Caribbean Regional Technical Assistance Center (CARTAC), the FSA should consider formulating a crisis management plan for the non-bank financial sector, in consultation with the MOF and the ECCB, and establishing a Financial Crisis Management Committee, which could involve representatives from the FSA, MOF, and ECCB. 


\section{Progress has been made in addressing remaining legal deficiencies in the AML/CFT}

framework. Banks have preserved their correspondent banking relationships, but credit unions have lost nested correspondent accounts with domestic banks. Last year, the government amended several AML/CFT related laws, which helped close many of deficiencies identified in the 2010 FATF recommendations. The authorities should now focus on ensuring the effectiveness of AML/CFT preventive measures. To this end, the authorities commenced the National Risk Assessment in 2017, which should help identify sectors and business activities at high risk to money laundering threats and assess the adequacy of the current legal framework. The authorities are committed to completing the assessment by September 2019.

\section{E. Other Issues}

\section{Macroeconomic data is broadly adequate for surveillance, but there remains room to} improve statistics. National accounts, external, and financial sector statistics are adequate and compliant with international standards. Statistical coverage of public sector entities, however, remains weak, given that several do not comply with financial reporting requirements, including due to lack of capacity. Labor statistics should also be strengthened, especially since the accuracy of the labor force survey conducted in 2017 is in dispute.

33. The last update safeguards assessment of the ECCB, completed in 2016, concluded that governance arrangements are sound. Recommendations of the assessment have since been implemented, and the annual financial statements continue to be prepared and audited in accordance with international practices.

\section{AUTHORITIES' VIEWS}

34. The authorities broadly agree with the staff's macroeconomic outlook. They are encouraged by the positive growth momentum generated by the new airport, with an increase in tourist arrivals and investor interest. The authorities expect real GDP to grow at around 21/4 percent in 2019 and beyond, supported by steady growth of tourist arrivals and investment in tourismrelated projects. With greater access to international markets, they see the opportunity to boost agricultural and fisheries exports, which will help diversify the economic structure. The geothermal project, when completed, will also boost competitiveness. The authorities view risks around the outlook to be tilted to the downside, due to natural disasters risks, but note the outlook's upside potential over the medium term.

\section{The authorities broadly agree with staff's recommendations on structural reforms.}

They agree that there is room to streamline the approval process of foreign investment. They view the existing tax incentive scheme as reasonably transparent but agree, that the costs and benefits of the existing scheme should be reviewed. The authorities also agree that procedural and legislative requirements on investment (currently specified in several regulations) can be consolidated in one standalone investment act. Regarding labor market policy, the authorities see the merits of taking stock of the past experiences of the TVET program, with a view to improve its effectiveness. 
36. The authorities remain committed to meeting the ECCU's debt-to-GDP target of $\mathbf{6 0}$ percent by 2030. To that end, they plan to restrain the growth of the wage bill to around $2 \frac{1}{2} 2$ percent per year over the medium term. They will also seek additional revenue and expenditure measures to create space for capital expenditure while the overall deficit is contained, consistent with this target. Progress has been made towards the implementation of the single TIN and the enactment of the TAPA, which will help strengthen tax and customs administration.

\section{The authorities see challenges in allocating expenditure reserves for emergency} operations in the budget. They argue that two revenue measures earmarked for the Contingencies Fund are already on the budget and an additional expenditure measure for emergency buffers, on top of those required to achieve the required primary balance to meet the debt to GDP target, would be burdensome. The authorities also note that in the event of a natural disaster, budget priorities would change, and they would find resources for emerging operations by reallocating resources from non-priority items without recourse to deficit financing. The authorities have agreed to assess the need to purchase more insurance in order to broaden and deepen risk transfer possibilities. They agree, also, that financial support from donors could be used to build further fiscal buffers against climate change events.

\section{The authorities note that a mechanism to monitor SOEs is already in place. Senior} government officials regularly attend SOEs' board meetings and report on SOEs' performance to the Office of the Prime Minister. To further strengthen oversight over SOEs, however, the authorities are currently preparing regulations that will require all commercial SOEs to submit to the MOF quarterly and annual financial and operational performance information within specified periods.

\section{The authorities concur that further efforts are warranted to make infrastructure more} resilient to natural disasters. They stress that the new airport is resilient. A new port under consideration and the ongoing projects on slope stabilization and coastal protection would all comply with resilient building standards.

40. The authorities broadly agree with staff's assessment on the financial system. They note that some locally-supervised financial institutions have high NPLs, and the implementation of IFRS 9 could raise their provisioning requirements and lower their capital. They, however, stress that none of these institutions is systemic, while they continue to maintain enhanced supervision of the BLA. The authorities underscored the progress made by the FSA in conducting stress testing of credit unions and the overall strengthening of the supervision of this growing subsector. They are also working to enact several pieces of legislation, including the regulations of the FSA Act, aimed at strengthening the FSA's enforcement powers. The authorities review and assess the resource adequacy of the FSA annually and adjust the FSA's resource requirements, if deemed necessary.

\section{STAFF APPRAISAL}

41. Economic recovery is underway. Growth in 2018 is on track to meet staff's projection of 2 percent. Real GDP growth is expected to further accelerate to around 2.3 percent in 2019 and be sustained at this level over the medium term, assuming steady tourism and investment growth. Risks to the outlook are tilted to the downside, largely due to natural disaster risks. 
42. With the economy turning the corner, the challenge is now how to sustain the growth momentum over the medium-term. The authorities need to advance structural reforms to capitalize on the growth opportunities created by the new airport and bring its benefits to broader economic sectors beyond tourism. The policies should focus on fostering private sector participation. To this end, further improving the investment environment and strengthening human and physical capital will be critical.

43. Fiscal buffers should be bolstered. The government's commitment to meeting the 60 percent of GDP debt target by 2030 is welcome. Staff recommends that the expected fiscal costs of natural disasters should be incorporated in the budget framework, with expenditure reserves allocated for emergency operations. To guard against fiscal risks, the authorities should take a more proactive fiscal policy, aimed at increasing the primary surplus to 1.6 percent of GDP within the next two years. To this end, additional fiscal measures should be introduced, for example, by broadening the tax base and moving resolutely with the plan to reform the pension system. The government should also prioritize developmental project plans, taking into account capacity and budget constraints, while seeking concessional financing and containing procurement costs.

44. More needs to be done to strengthen the institutional fiscal framework. The authorities should submit the MTFF together with the 2019 budget as planned. Moving towards a risk-based approach and completing the various reform initiatives (e.g., the full implementation of the single TIN and the enactment of the TAPA) are critical to strengthen revenue administration. In addition, the government's plan to issue regulations to strengthen the oversight of SOEs is welcome, but a legal and institutional framework to assess potential risks pertaining to PPPs should also be put in place.

45. The Contingency Fund is an important instrument to protect public finances from the impact of natural disasters and climate change. The authorities, however, need to legislate the Contingency Fund's governance and operational framework to ensure its effectiveness and transparency. Consideration should be given to expanding the coverage of disaster insurance, especially against floods to achieve additional buffers. Alongside, the authorities should continue to work on strengthening disaster preparedness. Priorities include updating the National Emergency and Disaster Act, river basin flood risk maps, and enhancing public education and awareness. Resources for the NEMO should be boosted for their effective post-disaster emergency operations.

46. Financial sector oversight should be further strengthened. The implementation of IFRS 9 may raise financial institutions' provisioning requirements and reduce their capital. To strengthen the FSA's enforcement power, the authorities should enact pending legislations, including regulations of the FSA Act. Staff also encourages the FSA to more periodically communicate its financial stability assessment to the public. Furthermore, building on earlier technical assistance provided by CARTAC, the authorities should move ahead with preparing a crisis management plan for the non-bank financial sector and setting up a Financial Crisis Management Committee.

47. Progress has been made in addressing remaining legal deficiencies in the AML/CFT framework. Last year, the government amended several AML/CFT related laws, which helped close 
many of the deficiencies identified in the 2010 AML/CFT assessment. The authorities should now focus on ensuring the effectiveness of AML/CFT preventative measures. To this end, the National Risk Assessment should be completed by September 2019.

48. It is recommended that the next Article IV consultation take place within the next 12 months. 
Figure 1. St. Vincent and the Grenadines: Key Macroeconomic Indicators 1/ GDP growth has been below the median of ECCU economies...

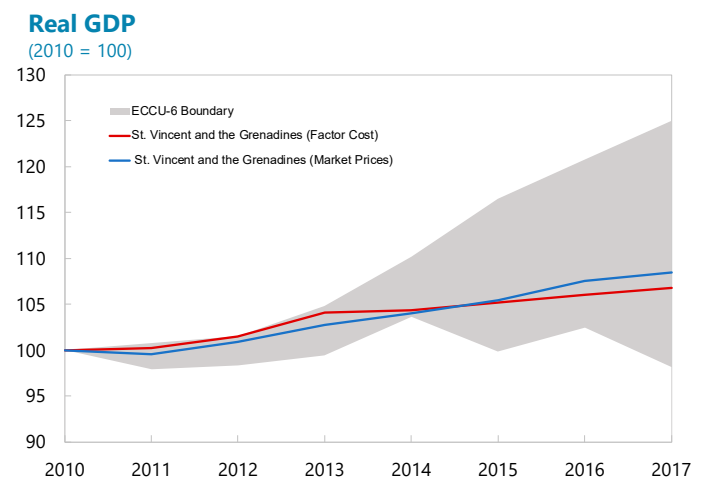

...with lackluster stay-over tourist arrivals.

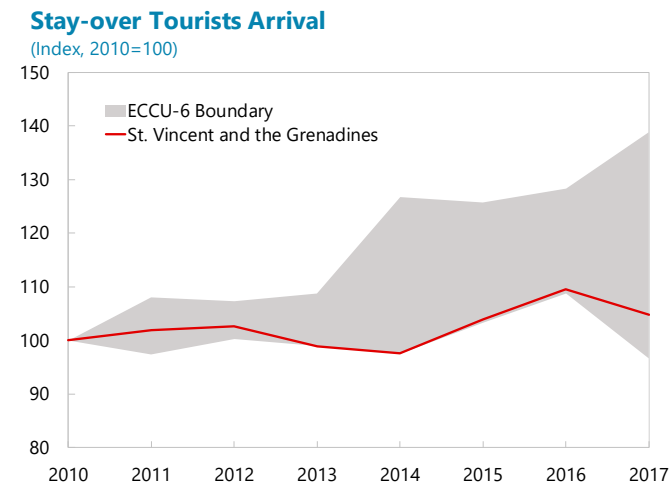

The current account deficit has been among the largest in the region.

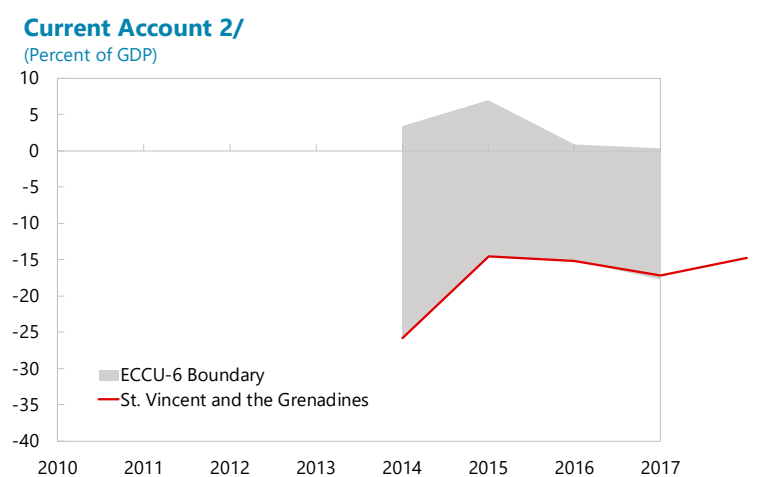

The fiscal position has broadly improved....

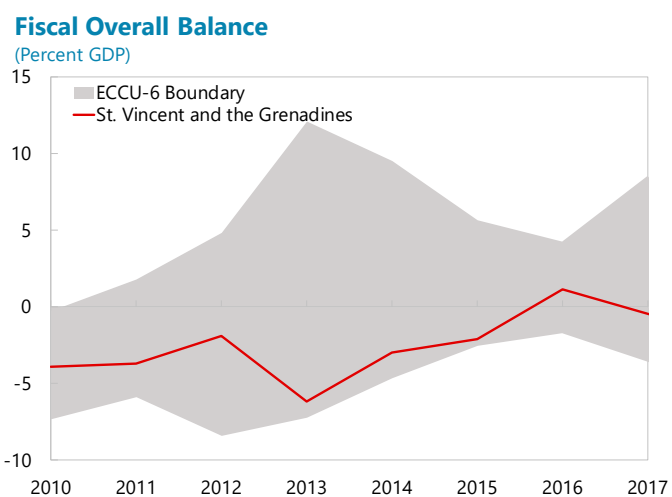

....and the public debt to GDP ratio fell in 2017

Meanwhile, total external debt remains relatively high.
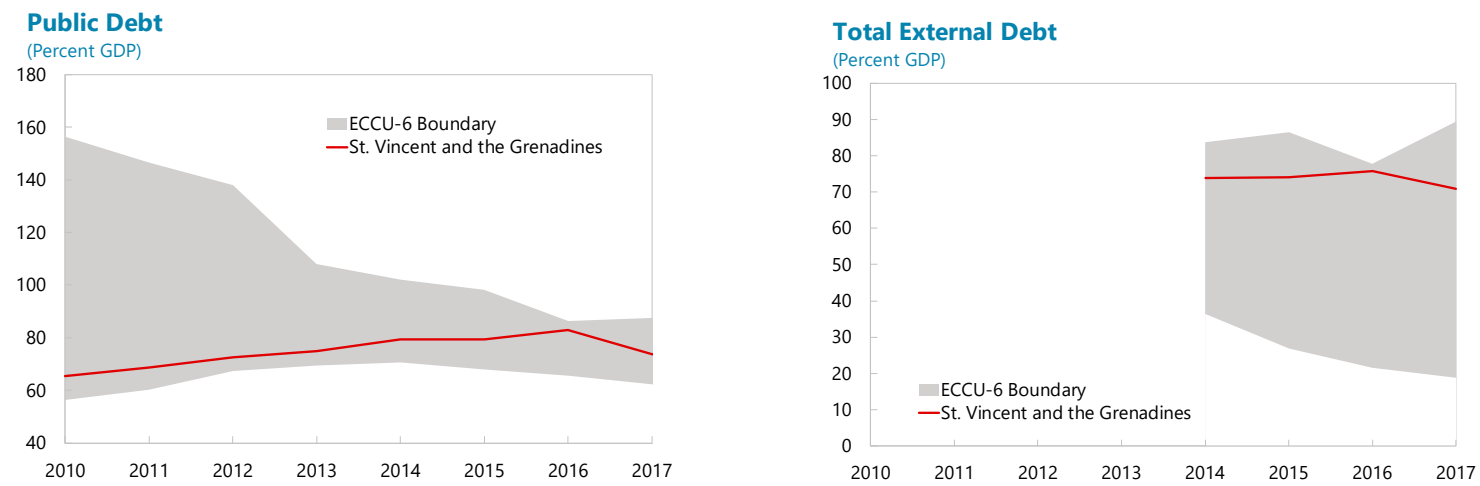

Source: Government Statistical Office; ECCB; Caribbean Tourism Organization; and IMF staff calculations.

1/ The ECCU-6 are: Antigua and Barbuda, Dominica, Grenada, St. Kitts and Nevis, St. Lucia, St. Vincent and the Grenadines. 2/ Based on BPM6. 
Figure 2. St. Vincent and the Grenadines: Real Sector Developments

GDP growth (factor prices) was lackluster in 2017...

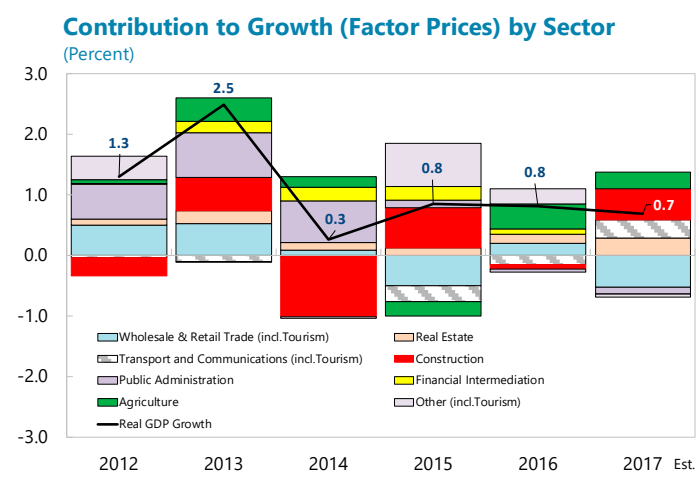

However, more recently, there are signs of a tourism recovery.

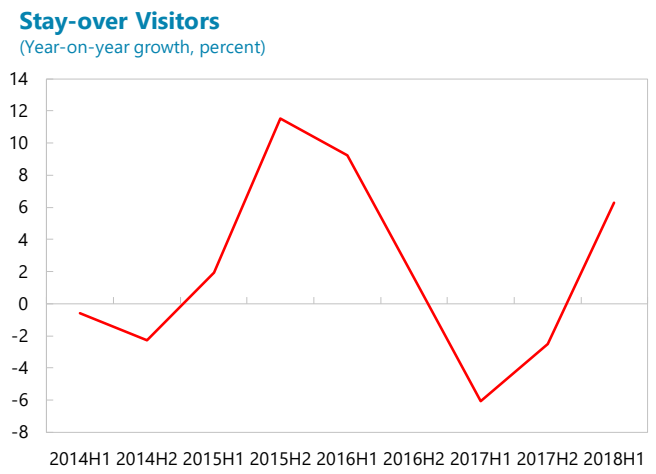

After the collapse of bananas in the early 2000s, the government has been promoting various crops in the agriculture sector.

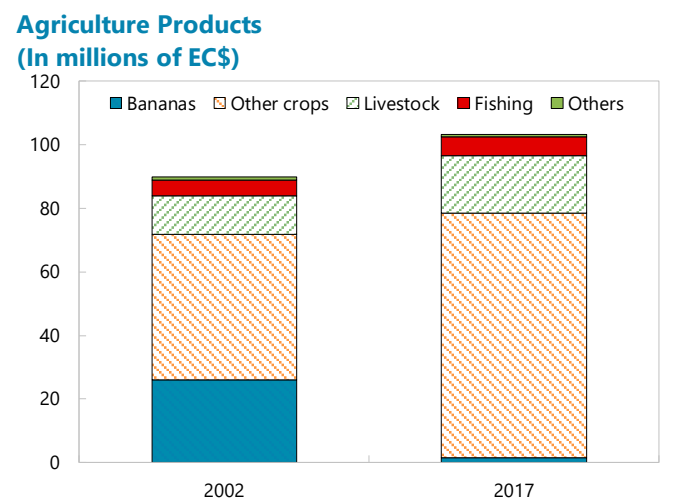

...with sluggish growth of tourism-related activities.

Tourism-related GDP

(Percent)

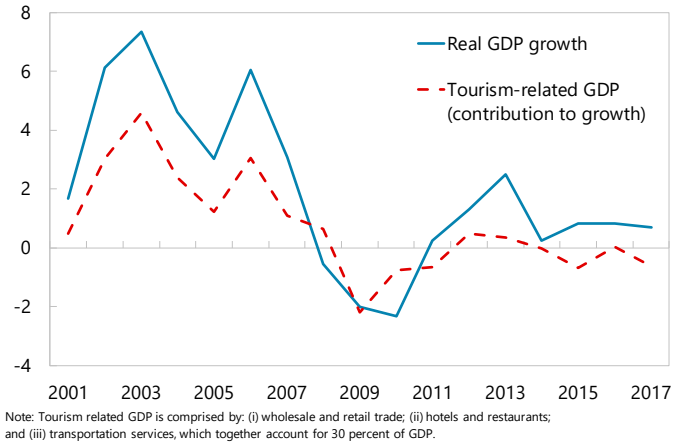

Construction picked up last year.

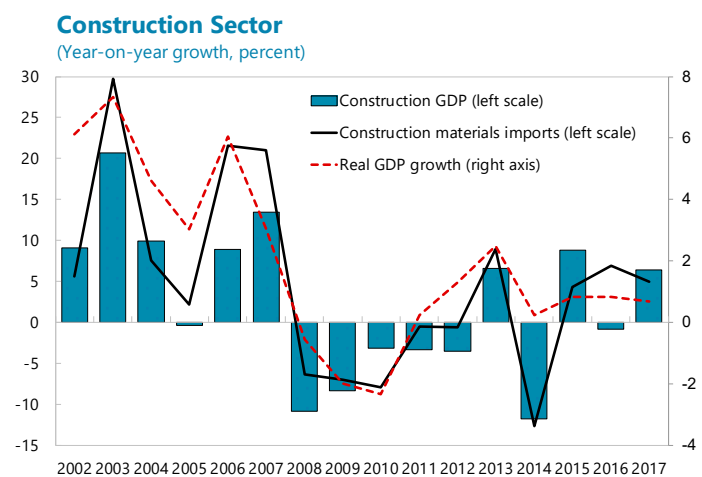

Inflation has recovered and been hovering around 2-3 percent, partly due to higher commodity and fuel prices.

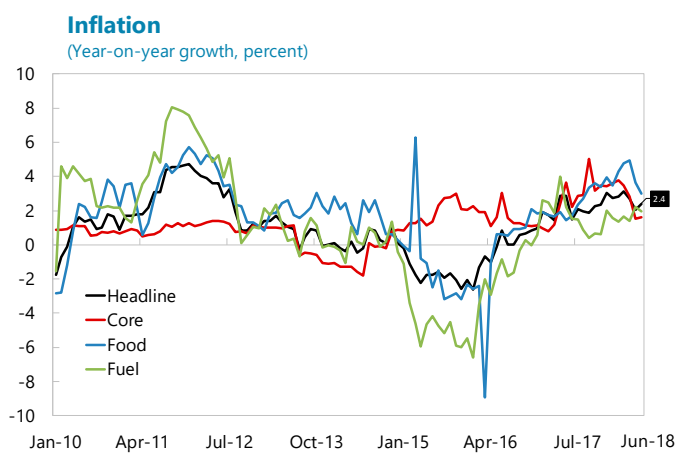

Source: Government Statistical Office; ECCB; and IMF staff calculations. 
Figure 3. St. Vincent and the Grenadines: External Sector Developments

Current account deficit is expected to slightly narrow in 2018.

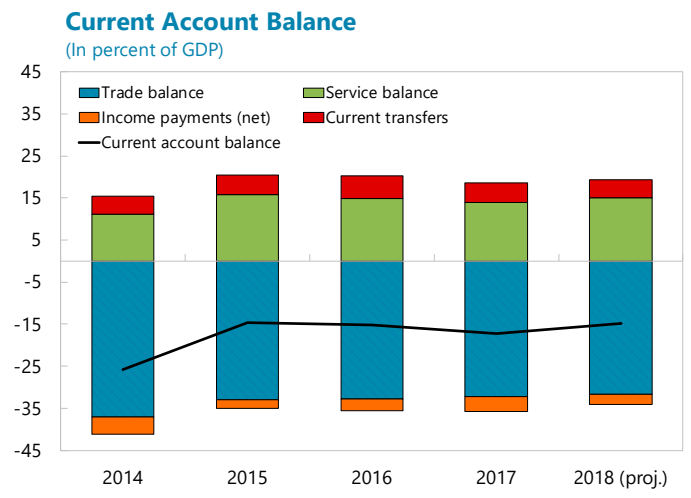

Real effective exchange rate slightly appreciated due to a stronger dollar.

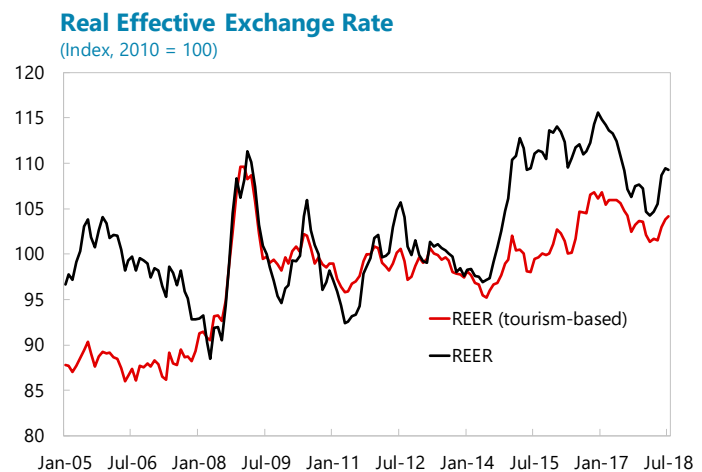

...but are still below many ECCU economies

Stayover tourist arrivals, 2017

(Number of tourists)

450,000

\begin{tabular}{l|l}
400,000 & $\square$ Total \\
350,000 & $\square$ USA \\
\hline
\end{tabular}

$350,000 \quad \square$ Canada

250,000

200,000

150,000

100,000

50,000

0

Anguilla Antigua Dominica Grenada St. Kitts \& St. Lucia St. Vincent Nevis
Current account deficit is mostly financed by FDI inflows.

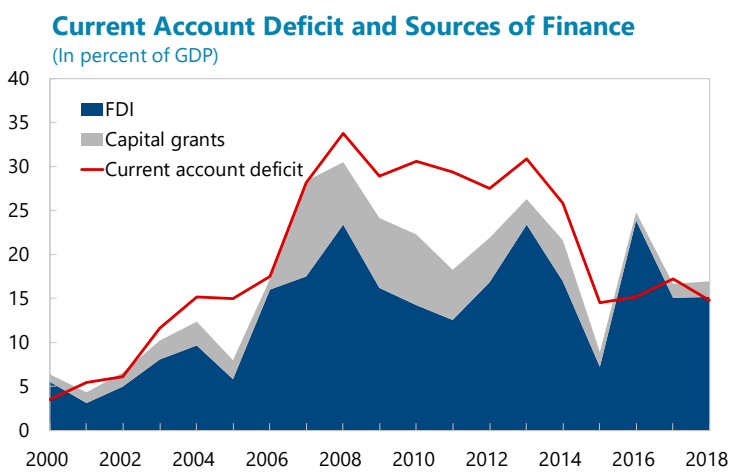

Starting with the year 2014 data are provided by the authorities in BPM6.

Stayover tourist arrivals are recovering...

Stayover Tourist Arrivals

(12-month moving sum; December 2004=100)

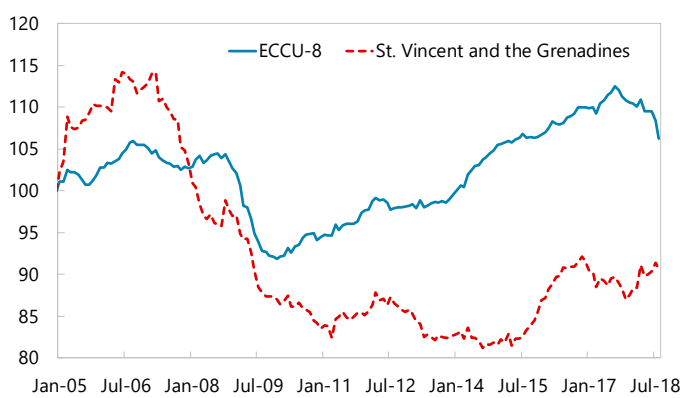

With increased direct flights, tourist arrivals from Canada, have grown strongly.

Tourist Arrivals by Country

(12-month moving sum; December $2004=100)$

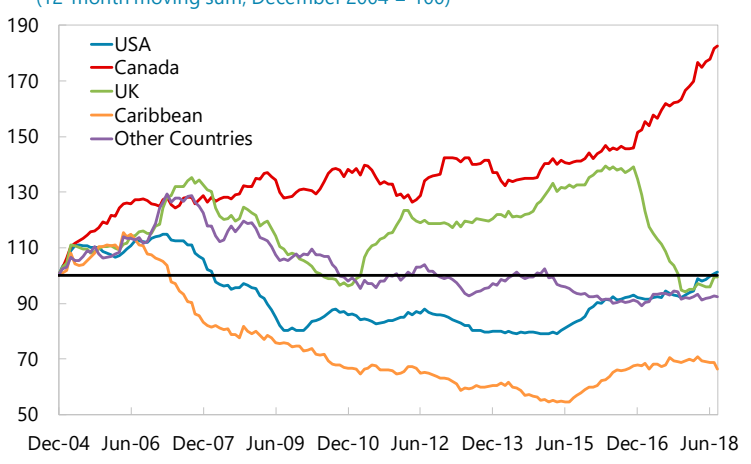

Source: Government Statistical Office; ECCB; Caribbean Tourism Organization; and IMF staff calculations. 
Figure 4. St. Vincent and the Grenadines: Fiscal Sector Developments

Actual deficits have consistently been below budget targets...

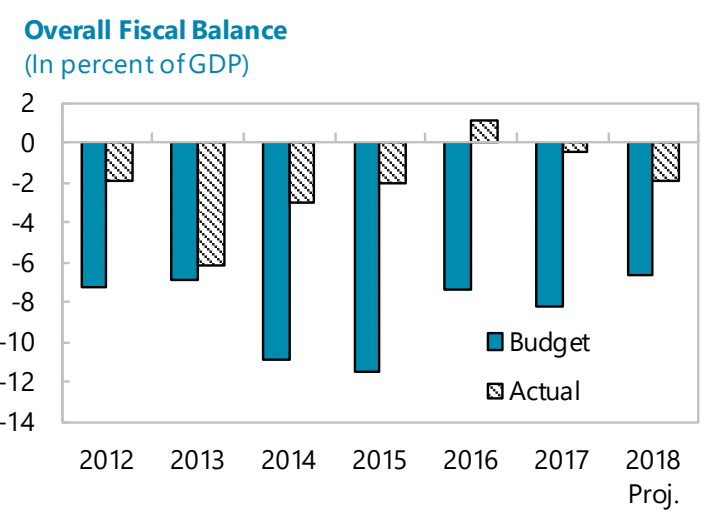

Revenues are expected to decline as a percent of GDP due to tax cuts in 2018...

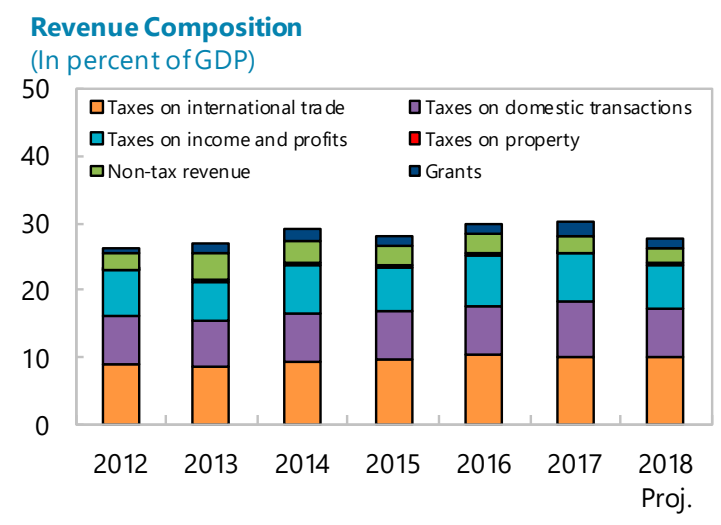

St. Vincent's wage bill is high compared to peer countries in the ECCU region.

ECCU: Wage Bill
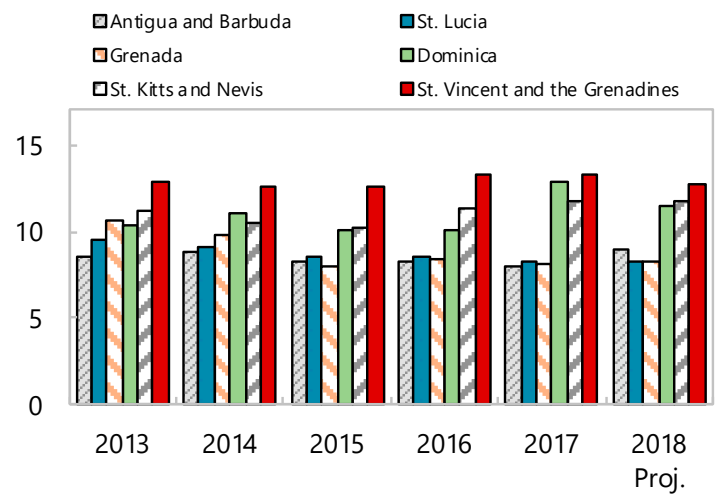

...in part due to lower-than expected execution of the capital budget.

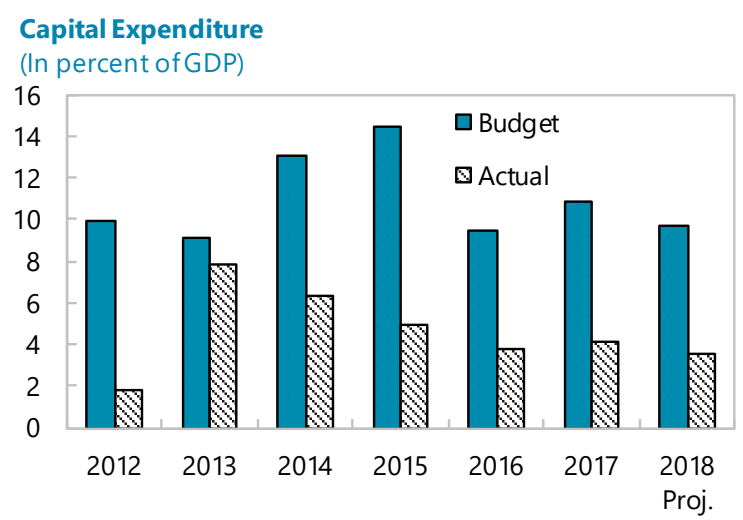

...while the wage bill and transfers and subsidies are expected to be well contained in 2018.

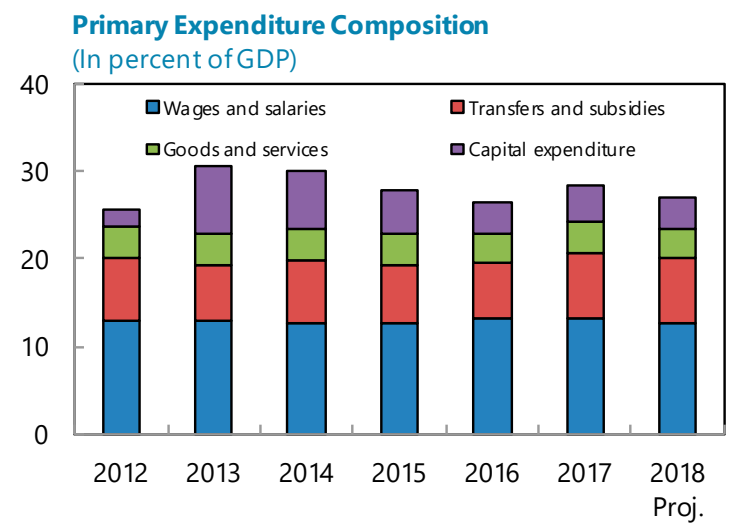

Most of the debt is with multilaterals and bilateral at concessional terms.

Public Debt

(In percent of GDP)

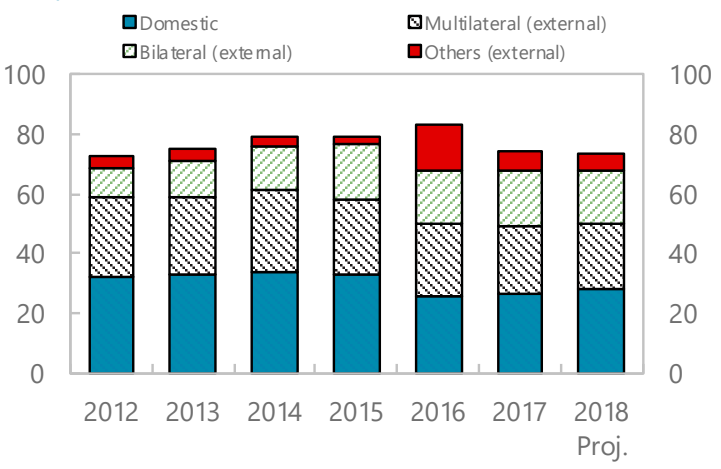

Source: St. Vincent and the Grenadines Authorities: IMF WEO database; and IMF staff's estimates and calculations. 
Figure 5. St. Vincent and the Grenadines: Financial Sector Developments

Banks' NPLs fell in 2017...

Commercial Banks: NPLs/Total Loans

(Percent)

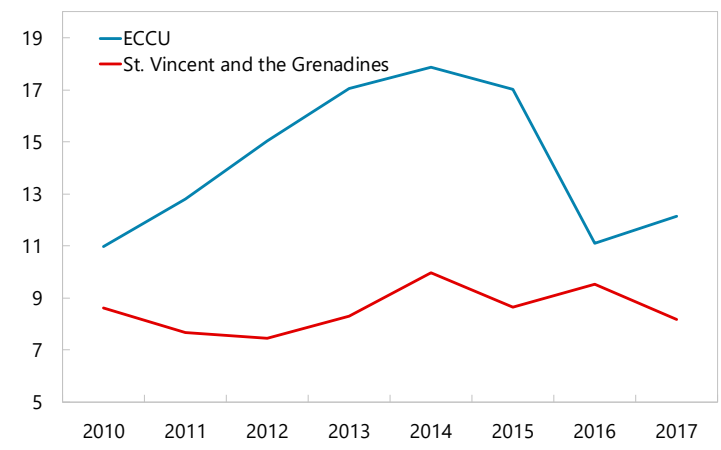

...while banks have maintained liquidity ratios at around 35-40 percent.

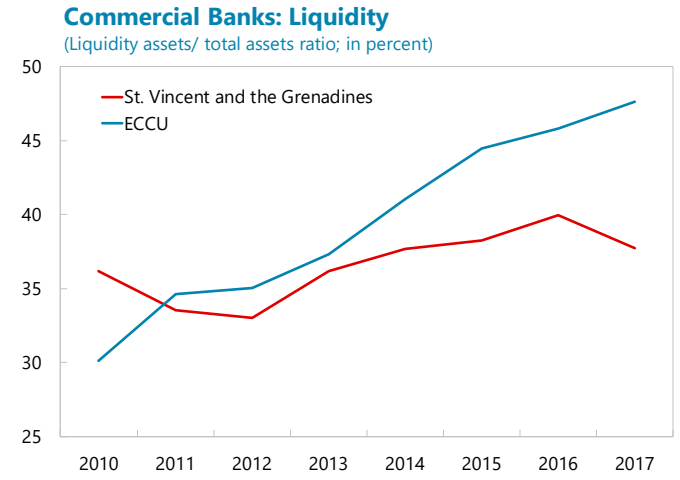

The majority of bank loans are for individuals.

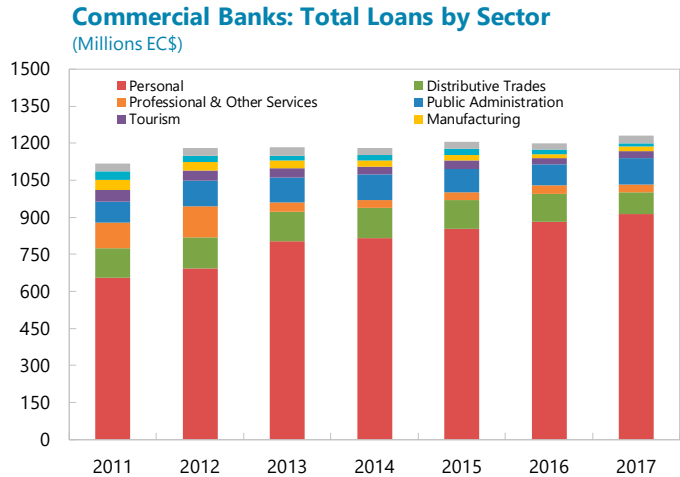

....and their capital ratios have remained above the

regulatory requirement...

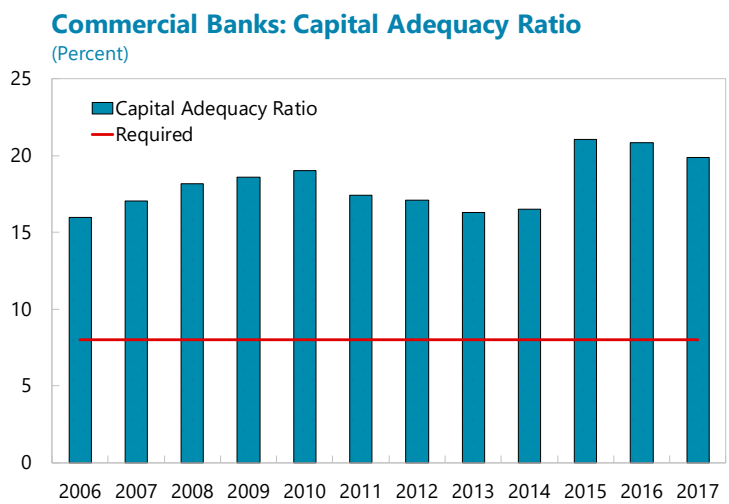

Banks' profitability, however, has been volatile.

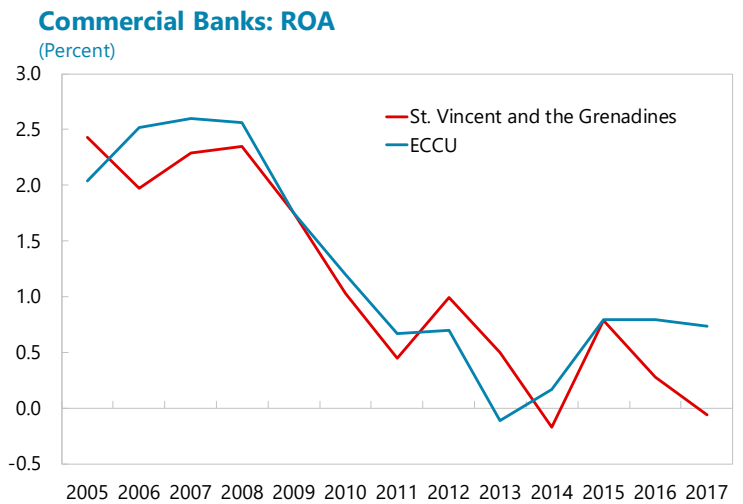

Like in other ECCU economies, credit union credit has grown fast.

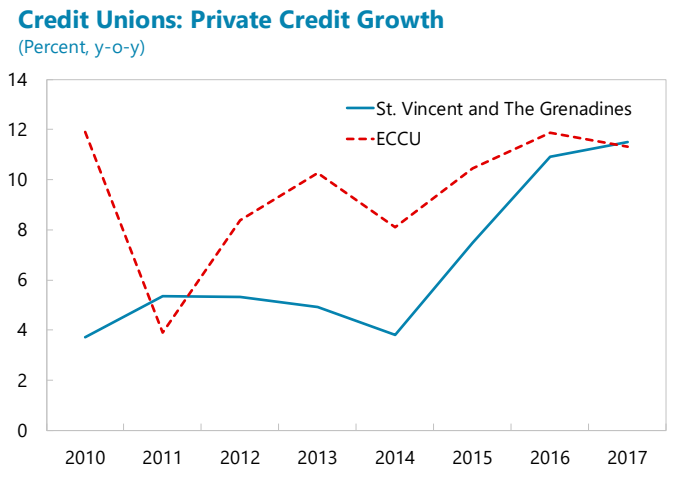

Source: Government Statistical Office; ECCB; and IMF staff calculations. 
Table 1. St. Vincent and the Grenadines: Selected Social and Economic Indicators, 2014-19

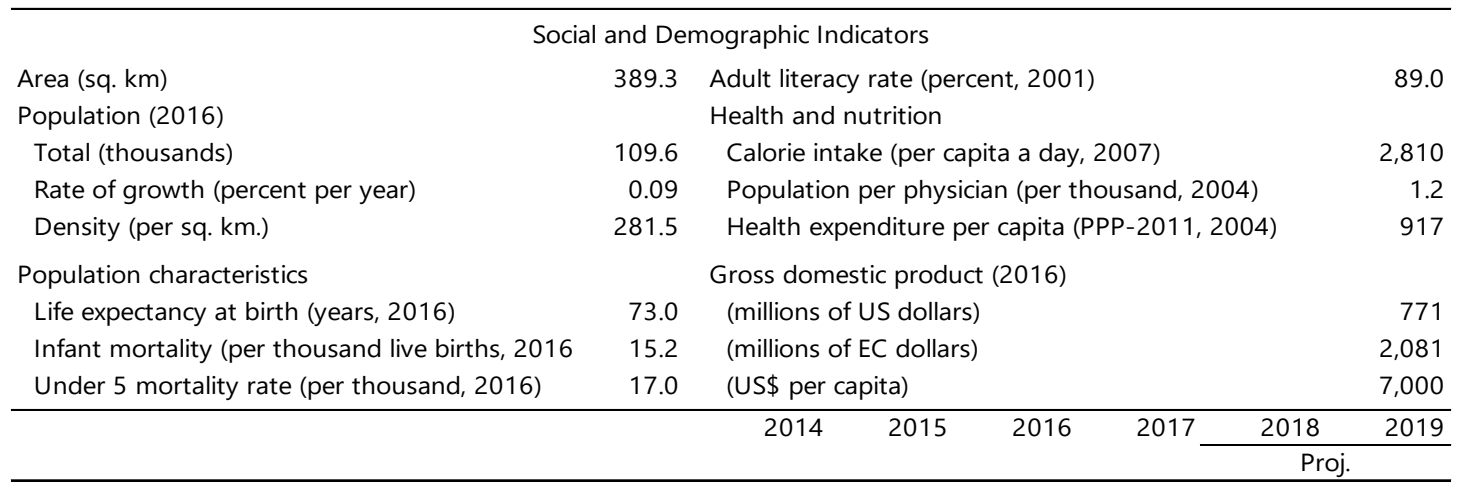

Output and prices

(Annual percentage change, unless otherwise specified)

Real GDP (factor cost)

Real GDP (market prices)

Nominal GDP (market prices)

Consumer prices, end of period

Consumer prices, period average

\section{Banking system 1/}

Net foreign assets

Net domestic assets

Credit to private sector

Central government finances (in percent of GDP)

Total revenue

Tax revenue

Grants

Total expenditure and net lending

Current expenditure

Wages and salaries

Interest

Capital expenditure

Overall balance

Overall balance (excl. grants)

Primary balance

Primary balance (excl. grants)

\section{External sector (in percent of GDP)}

External current account

Exports of goods and services

Imports of goods and services

Public sector external debt (end of period)

External public debt service

(In percent of exports of goods and services)

\section{Memorandum items}

Gross public sector debt (in percent of GDP) 2/ Nominal GDP (market prices; in millions of EC\$)
0.2

1.2

0.9

0.1

0.2

$$
1.1
$$$$
8.4
$$$$
-0.2
$$

$$
0.8
$$$$
1.3
$$$$
3.8
$$$$
-2.1
$$

\begin{tabular}{|c|c|c|c|c|c|}
\hline 0.2 & 0.8 & 0.8 & 0.7 & 2.0 & 2.3 \\
\hline 1.2 & 1.3 & 2.0 & 0.9 & 2.0 & 2.3 \\
\hline 0.9 & 3.8 & 2.0 & 1.9 & 5.2 & 4.6 \\
\hline 0.1 & -2.1 & 1.0 & 3.0 & 2.0 & 2.0 \\
\hline 0.2 & -1.7 & -0.2 & 2.2 & 2.4 & 2.0 \\
\hline 1.1 & 1.7 & 8.8 & -2.6 & -0.9 & 3.4 \\
\hline 8.4 & 12.0 & -14.3 & 3.8 & 1.9 & 1.8 \\
\hline-0.2 & 1.7 & 1.0 & 1.1 & -0.1 & 1.3 \\
\hline 29.3 & 27.9 & 29.8 & 30.3 & 27.8 & 28.2 \\
\hline 24.0 & 23.6 & 25.5 & 25.7 & 24.1 & 24.4 \\
\hline 2.0 & 1.2 & 1.2 & 2.1 & 1.4 & 1.4 \\
\hline 32.3 & 30.0 & 28.7 & 30.8 & 29.8 & 29.9 \\
\hline 25.9 & 25.1 & 24.9 & 26.7 & 26.2 & 26.0 \\
\hline 12.6 & 12.6 & 13.2 & 13.3 & 12.8 & 12.7 \\
\hline 2.3 & 2.2 & 2.1 & 2.3 & 2.6 & 2.4 \\
\hline 6.4 & 4.9 & 3.8 & 4.1 & 3.6 & 3.9 \\
\hline-3.0 & -2.1 & 1.1 & -0.5 & -2.0 & -1.7 \\
\hline-5.0 & -3.3 & -0.1 & -2.6 & -3.4 & -3.1 \\
\hline-0.7 & 0.1 & 3.2 & 1.9 & 0.6 & 0.8 \\
\hline-2.7 & -1.1 & 1.9 & -0.2 & -0.8 & -0.6 \\
\hline-25.8 & -14.5 & -15.2 & -17.2 & -15.9 & -15.0 \\
\hline 35.2 & 37.4 & 37.9 & 36.0 & 37.2 & 37.9 \\
\hline 61.1 & 54.5 & 55.7 & 54.3 & 55.0 & 54.0 \\
\hline 45.5 & 46.4 & 56.7 & 47.4 & 44.8 & 45.0 \\
\hline 12.6 & 10.3 & 27.7 & 51.0 & 28.4 & 15.2 \\
\hline 79.4 & 79.4 & 82.8 & 74.2 & 73.1 & 71.4 \\
\hline, 965 & 2,040 & 2,081 & 2,120 & 2,231 & 2,334 \\
\hline
\end{tabular}$$
-1.7
$$

$1,965 \quad 2,040$

2/From 2016, reflects additional debt contracted with PetroCaribe but not previously recorded (EC\$112 million or 5.4 percent

of GDP in 2016). It includes debt of central government and state-owned enterprises.

CInternational Monetary Fund. Not for Redistribution 
Table 2. St. Vincent and the Grenadines: Balance of Payments Summary, 2014-23 1/ (In millions of Eastern Caribbean dollars, unless otherwise stated)

\begin{tabular}{|c|c|c|c|c|c|c|c|c|c|c|}
\hline & 2014 & 2015 & 2016 & 2017 & 2018 & 2019 & 2020 & 2021 & 2022 & 2023 \\
\hline & & & & & \multicolumn{6}{|c|}{ Projections } \\
\hline Current account & -506.8 & -296.5 & -316.0 & -365.0 & -355.9 & -351.1 & -343.5 & -336.8 & -329.9 & -319.8 \\
\hline Trade balance & -728.9 & -670.9 & -680.7 & -683.8 & -732.5 & -744.0 & -757.5 & -782.0 & -805.1 & -825.8 \\
\hline Exports f.o.b. & 133.9 & 125.0 & 116.2 & 100.2 & 112.3 & 118.0 & 127.5 & 133.9 & 150.8 & 172.2 \\
\hline Imports f.o.b. & 862.8 & 795.9 & 796.9 & 784.0 & 844.8 & 862.0 & 884.9 & 915.9 & 956.0 & 997.9 \\
\hline Of which: Mineral fuels 2/ & 205.6 & 108.3 & 106.2 & 82.8 & 109.2 & 96.3 & 98.3 & 99.8 & 101.9 & 104.8 \\
\hline Services (net) & 219.0 & 322.4 & 311.2 & 296.5 & 335.6 & 367.2 & 400.2 & 436.8 & 468.3 & 502.0 \\
\hline Travel & 416.5 & 496.2 & 523.2 & 510.1 & 558.4 & 599.2 & 642.7 & 689.5 & 732.1 & 777.2 \\
\hline Other nonfactor services & -197.5 & -173.9 & -212.0 & -213.6 & -222.8 & -232.0 & -242.5 & -252.8 & -263.7 & -275.3 \\
\hline Income payments (net) & -81.0 & -42.4 & -58.1 & -75.5 & -55.0 & -68.7 & -80.5 & -85.9 & -88.1 & -91.9 \\
\hline Current transfers & 84.1 & 94.4 & 111.7 & 97.7 & 96.1 & 94.4 & 94.2 & 94.4 & 94.9 & 95.9 \\
\hline Net private transfers & 88.5 & 85.7 & 89.7 & 75.4 & 72.7 & 70.6 & 69.1 & 69.1 & 69.1 & 69.1 \\
\hline Net official transfers & -4.3 & 8.8 & 21.9 & 22.3 & 23.4 & 23.8 & 25.1 & 25.3 & 25.9 & 26.8 \\
\hline Capital & 86.7 & 31.1 & 17.2 & 28.9 & 31.5 & 32.7 & 34.1 & 35.6 & 37.2 & 38.8 \\
\hline Financial (net) & -440.8 & -221.5 & -339.9 & -255.6 & -304.5 & -324.0 & -327.9 & -320.4 & -319.1 & -311.9 \\
\hline Net Foreign Direct Investment & -311.3 & -133.8 & -438.5 & -277.5 & -279.7 & -291.8 & -304.3 & -317.1 & -330.5 & -344.9 \\
\hline Portfolio investment & -19.8 & -8.8 & 7.7 & 11.4 & -6.9 & -3.0 & -3.1 & -4.3 & 1.0 & 4.8 \\
\hline Commercial banks & -29.7 & -16.1 & 58.9 & -23.8 & 6.3 & 13.8 & -1.2 & 6.3 & 6.3 & 3.8 \\
\hline Others (incl. official capital) & -80.1 & -62.8 & 32.0 & 34.3 & -24.3 & -42.9 & -19.4 & -5.2 & 4.2 & 24.4 \\
\hline Available financing & -60.5 & -41.5 & -53.9 & 27.8 & 19.9 & -5.5 & -18.6 & -19.2 & -26.3 & -30.9 \\
\hline Change in ECCB NFA & -60.5 & -41.5 & -53.9 & 27.8 & 19.9 & -5.5 & -18.6 & -19.2 & -26.3 & -30.9 \\
\hline Change in net imputed reserves (increase -) & -62.0 & -41.4 & -53.4 & 29.2 & 21.4 & -4.0 & -17.1 & -17.7 & -24.9 & -29.4 \\
\hline of which: IMF purchases and disbursements $3 /$ & -15.7 & 2.8 & 3.6 & 6.2 & 8.5 & 6.8 & 4.1 & 3.3 & 1.6 & 1.6 \\
\hline Change in SDR Allocation & 1.5 & -0.1 & -0.5 & -1.5 & -1.5 & -1.5 & -1.5 & -1.5 & -1.5 & -1.5 \\
\hline Change in govt. foreign assets & 0.0 & 0.0 & 0.0 & 0.0 & 0.0 & 0.0 & 0.0 & 0.0 & 0.0 & 0.0 \\
\hline Other financing & 0.0 & 0.0 & 0.0 & 0.0 & 0.0 & 0.0 & 0.0 & 0.0 & 0.0 & 0.0 \\
\hline Errors and omissions & 39.8 & 85.5 & 12.8 & 52.8 & 0.0 & 0.0 & 0.0 & 0.0 & 0.0 & 0.0 \\
\hline \multicolumn{11}{|c|}{ (In percent of GDP, unless otherwise stated) } \\
\hline \multicolumn{11}{|l|}{ Memorandum items: } \\
\hline Current account & -25.8 & -14.5 & -15.2 & -17.2 & -15.9 & -15.0 & -14.1 & -13.2 & -12.4 & -11.5 \\
\hline Exports f.o.b. & 6.8 & 6.1 & 5.6 & 4.7 & 5.0 & 5.1 & 5.2 & 5.3 & 5.7 & 6.2 \\
\hline Imports f.o.b. & 43.9 & 39.0 & 38.3 & 37.0 & 37.9 & 36.9 & 36.3 & 36.0 & 36.0 & 36.0 \\
\hline Net private transfers & 4.5 & 4.2 & 4.3 & 3.6 & 3.3 & 3.0 & 2.8 & 2.7 & 2.6 & 2.5 \\
\hline Foreign direct investment & -15.8 & -6.6 & -21.1 & -13.1 & -12.5 & -12.5 & -12.5 & -12.5 & -12.4 & -12.4 \\
\hline Tourism receipts & 24.1 & 27.4 & 28.1 & 27.0 & 27.9 & 28.6 & 29.2 & 30.0 & 30.5 & 30.9 \\
\hline Terms of Trade of Goods (Index 2002 $=100)$ & 102.4 & 99.7 & 97.6 & 96.0 & 97.2 & 98.0 & 100.4 & 100.5 & 100.6 & 100.6 \\
\hline Total trade of goods and nonfactor services & 96.3 & 91.9 & 93.7 & 90.3 & 92.2 & 91.9 & 92.1 & 92.6 & 93.5 & 94.6 \\
\hline Exports of goods and nonfactor services & 35.2 & 37.4 & 37.9 & 36.0 & 37.2 & 37.9 & 38.7 & 39.5 & 40.4 & 41.4 \\
\hline Imports of goods and nonfactor services & 61.1 & 54.5 & 55.7 & 54.3 & 55.0 & 54.0 & 53.4 & 53.1 & 53.1 & 53.1 \\
\hline
\end{tabular}


Table 3. St. Vincent and the Grenadines: Summary of Central Government Operations, 2014-2019

(In millions of Eastern Caribbean dollars; unless otherwise stated)

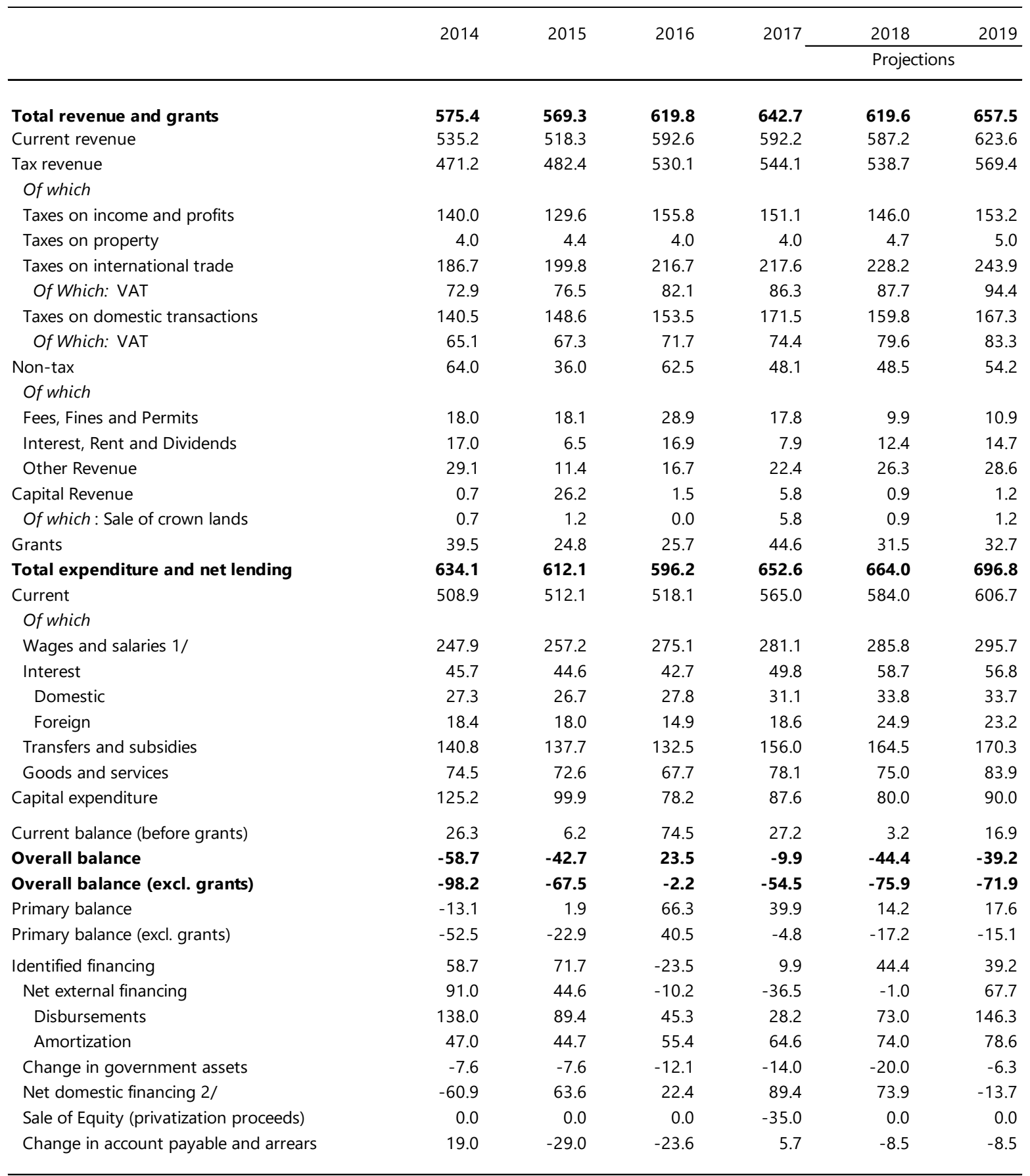

Sources: Ministry of Finance and Planning; and IMF staff estimates and projections.

$1 /$ Wages and salaries including social security contributions, commissions, rewards, allowances, and incentives.

2/ Includes other non-banking sector domestic financing. 
Table 4. St. Vincent and the Grenadines: Summary of Central Government Operations, 2014-2019

(In percent of GDP; unless otherwise stated)

\begin{tabular}{|c|c|c|c|c|c|c|}
\hline & \multirow[t]{2}{*}{2014} & \multirow[t]{2}{*}{2015} & \multirow[t]{2}{*}{2016} & \multirow[t]{2}{*}{2017} & 2018 & 2019 \\
\hline & & & & & \multicolumn{2}{|c|}{ Projections } \\
\hline Total revenue and grants & 29.3 & 27.9 & 29.8 & 30.3 & 27.8 & 28.2 \\
\hline Current revenue & 27.2 & 25.4 & 28.5 & 27.9 & 26.3 & 26.7 \\
\hline Tax revenue & 24.0 & 23.6 & 25.5 & 25.7 & 24.1 & 24.4 \\
\hline \multicolumn{7}{|l|}{ Of which } \\
\hline Taxes on income and profits & 7.1 & 6.4 & 7.5 & 7.1 & 6.5 & 6.6 \\
\hline Taxes on property & 0.2 & 0.2 & 0.2 & 0.2 & 0.2 & 0.2 \\
\hline Taxes on international trade & 9.5 & 9.8 & 10.4 & 10.3 & 10.2 & 10.5 \\
\hline Of Which: VAT & 3.7 & 3.8 & 3.9 & 4.1 & 3.9 & 4.0 \\
\hline Taxes on domestic transactions & 7.1 & 7.3 & 7.4 & 8.1 & 7.2 & 7.2 \\
\hline Of Which: VAT & 3.3 & 3.3 & 3.4 & 3.5 & 3.6 & 3.6 \\
\hline Non-tax & 3.3 & 1.8 & 3.0 & 2.3 & 2.2 & 2.3 \\
\hline \multicolumn{7}{|l|}{ of which } \\
\hline Fees, Fines and Permits & 0.9 & 0.9 & 1.4 & 0.8 & 0.4 & 0.5 \\
\hline Interest, Rent and Dividends & 0.9 & 0.3 & 0.8 & 0.4 & 0.6 & 0.6 \\
\hline Other Revenue & 1.5 & 0.6 & 0.8 & 1.1 & 1.2 & 1.2 \\
\hline Capital Revenue & 0.0 & 1.3 & 0.1 & 0.3 & 0.0 & 0.1 \\
\hline Of which: Sale of crown lands & 0.0 & 0.1 & 0.0 & 0.3 & 0.0 & 0.1 \\
\hline Grants & 2.0 & 1.2 & 1.2 & 2.1 & 1.4 & 1.4 \\
\hline Total expenditure and net lending & 32.3 & 30.0 & 28.7 & 30.8 & 29.8 & 29.9 \\
\hline Current & 25.9 & 25.1 & 24.9 & 26.7 & 26.2 & 26.0 \\
\hline \multicolumn{7}{|l|}{ Of which } \\
\hline Wages and salaries $1 /$ & 12.6 & 12.6 & 13.2 & 13.3 & 12.8 & 12.7 \\
\hline Interest & 2.3 & 2.2 & 2.1 & 2.3 & 2.6 & 2.4 \\
\hline Domestic & 1.4 & 1.3 & 1.3 & 1.5 & 1.5 & 1.4 \\
\hline Foreign & 0.9 & 0.9 & 0.7 & 0.9 & 1.1 & 1.0 \\
\hline Transfers and subsidies & 7.2 & 6.8 & 6.4 & 7.4 & 7.4 & 7.3 \\
\hline Goods and services & 3.8 & 3.6 & 3.3 & 3.7 & 3.4 & 3.6 \\
\hline Capital expenditure & 6.4 & 4.9 & 3.8 & 4.1 & 3.6 & 3.9 \\
\hline Current balance (before grants) & 1.3 & 0.3 & 3.6 & 1.3 & 0.1 & 0.7 \\
\hline Overall balance & -3.0 & -2.1 & 1.1 & -0.5 & -2.0 & -1.7 \\
\hline Overall balance (excl. grants) & -5.0 & -3.3 & -0.1 & -2.6 & -3.4 & -3.1 \\
\hline Primary balance & -0.7 & 0.1 & 3.2 & 1.9 & 0.6 & 0.8 \\
\hline Primary balance (excl. grants) & -2.7 & -1.1 & 1.9 & -0.2 & -0.8 & -0.6 \\
\hline Identified financing & 3.0 & 3.5 & -1.1 & 0.5 & 2.0 & 1.7 \\
\hline Net external financing & 4.6 & 2.2 & -0.5 & -1.7 & 0.0 & 2.9 \\
\hline Disbursements & 7.0 & 4.4 & 2.2 & 1.3 & 3.3 & 6.3 \\
\hline Amortization & 2.4 & 2.2 & 2.7 & 3.0 & 3.3 & 3.4 \\
\hline Change in government assets & -0.4 & -0.4 & -0.6 & -0.7 & -0.9 & -0.3 \\
\hline Net domestic financing $2 /$ & -3.1 & 3.1 & 1.1 & 4.2 & 3.3 & -0.6 \\
\hline Sale of Equity (privatization proceeds) & 0.0 & 0.0 & 0.0 & -1.7 & 0.0 & 0.0 \\
\hline Change in account payable and arrears & 1.0 & -1.4 & -1.1 & 0.3 & -0.4 & -0.4 \\
\hline \multicolumn{7}{|l|}{ Memorandum items: } \\
\hline Gross public sector debt 3/ & 79.4 & 79.4 & 82.8 & 74.2 & 73.1 & 71.4 \\
\hline \multicolumn{7}{|l|}{ Central government debt service to revenues } \\
\hline excl. grants & 22.3 & 21.2 & 20.5 & 23.8 & 27.9 & 26.6 \\
\hline Stock of accounts payable/arrears & 4.5 & 3.0 & 1.8 & 2.0 & 1.5 & 1.1 \\
\hline
\end{tabular}

Sources: Ministry of Finance and Planning; and IMF staff estimates and projections.

1 / Wages and salaries including social security contributions, commissions, rewards, allowances, and incentives. 2/ Includes other non-banking sector domestic financing.

3/ From 2016, reflects additional debt contracted with PetroCaribe but not previously recorded (EC\$ 112 million or 5.4 percent of GDP in 2016). It includes debt of central government and state-owned enterprises. 
Table 5. St. Vincent and the Grenadines: Monetary Survey, 2014-2019

(In millions of Eastern Caribbean dollars)

\begin{tabular}{|c|c|c|c|c|c|c|}
\hline & 2014 & 2015 & 2016 & 2017 & 2018 & 2019 \\
\hline & & & & & \multicolumn{2}{|c|}{ Projections } \\
\hline Net foreign assets & 508.2 & 531.9 & 661.8 & 622.5 & 608.2 & 661.0 \\
\hline $\mathrm{ECCB}$ & 421.4 & 444.8 & 516.2 & 487.0 & 465.6 & 469.7 \\
\hline Of which: Imputed reserves & 421.4 & 444.8 & 516.2 & 487.0 & 465.6 & 469.7 \\
\hline Commercial banks & 86.8 & 87.1 & 145.6 & 135.5 & 142.5 & 191.4 \\
\hline Net domestic assets & 900.4 & $1,069.4$ & 858.9 & 916.7 & 946.1 & 974.1 \\
\hline Public sector credit (net) & -25.0 & -0.5 & -38.6 & -10.0 & 27.4 & 34.8 \\
\hline Central government & 88.6 & 111.2 & 60.4 & 95.2 & 109.5 & 89.4 \\
\hline $\mathrm{ECCB}$ & -8.7 & -1.9 & -3.5 & -2.7 & -2.7 & -2.7 \\
\hline Commercial banks & 97.3 & 113.1 & 63.9 & 97.9 & 112.2 & 92.2 \\
\hline Net credit to other public sector institutions & -113.6 & -111.7 & -99.0 & -105.1 & -82.1 & -54.6 \\
\hline National Insurance Scheme & -61.5 & -72.7 & -53.5 & -71.1 & -71.1 & -71.1 \\
\hline Other & -52.2 & -39.0 & -45.6 & -34.1 & -11.0 & 16.5 \\
\hline Credit to private sector & $1,045.3$ & $1,069.9$ & $1,084.1$ & $1,101.0$ & $1,098.7$ & $1,119.6$ \\
\hline Of which: Net credit to nonbank financial institutions & 16.1 & 15.5 & 23.4 & 32.6 & 34.3 & 35.8 \\
\hline Other items (net) & -119.8 & -125.5 & -186.5 & -174.3 & -180.0 & -180.4 \\
\hline Broad money (M2) & $1,408.6$ & $1,475.8$ & $1,520.7$ & $1,539.2$ & $1,554.2$ & $1,635.1$ \\
\hline Money & 426.3 & 437.8 & 479.8 & 475.8 & 471.0 & 499.0 \\
\hline Currency in circulation & 53.6 & 64.6 & 91.7 & 95.9 & 83.9 & 87.8 \\
\hline Demand deposits & 364.3 & 364.1 & 379.6 & 371.2 & 378.2 & 401.8 \\
\hline $\mathrm{EC} \$$ Cheques and Drafts issued & 8.4 & 9.2 & 8.5 & 8.8 & 8.9 & 9.5 \\
\hline Quasi-money & 982.3 & $1,037.9$ & $1,040.9$ & $1,063.4$ & $1,083.3$ & $1,136.1$ \\
\hline Time deposits & 130.1 & 126.9 & 114.2 & 110.1 & 112.2 & 119.2 \\
\hline Savings deposits & 779.4 & 820.6 & 845.2 & 875.8 & 892.2 & 933.1 \\
\hline \multirow[t]{2}{*}{ Foreign currency deposits } & 72.8 & 90.4 & 81.5 & 77.5 & 78.9 & 83.9 \\
\hline & \multicolumn{6}{|c|}{ (Annual percentage change) } \\
\hline Net foreign assets & 2.8 & 4.7 & 24.4 & -5.9 & -2.3 & 8.7 \\
\hline Net domestic assets & 13.7 & 18.8 & -19.7 & 6.7 & 3.2 & 3.0 \\
\hline Credit to private sector & -0.2 & 2.4 & 1.3 & 1.6 & -0.2 & 1.9 \\
\hline Broad money (M2) & 9.5 & 4.8 & 3.0 & 1.2 & 1.0 & 5.2 \\
\hline Money & 13.9 & 2.7 & 9.6 & -0.8 & -1.0 & 5.9 \\
\hline \multirow[t]{2}{*}{ Quasi-money 1/ } & 7.7 & 5.7 & 0.3 & 2.2 & 1.9 & 4.9 \\
\hline & \multicolumn{6}{|c|}{ (Contribution to M2 growth) } \\
\hline Net foreign assets & 1.1 & 1.7 & 8.8 & -2.6 & -0.9 & 3.4 \\
\hline Net domestic assets & 8.4 & 12.0 & -14.3 & 3.8 & 1.9 & 1.8 \\
\hline Public sector credit (net) & 1.9 & 1.7 & -2.6 & 1.9 & 2.4 & 0.5 \\
\hline Of which: Central government & 2.1 & 1.6 & -3.4 & 2.3 & 0.9 & -1.3 \\
\hline Credit to private sector & -0.2 & 1.7 & 1.0 & 1.1 & -0.1 & 1.3 \\
\hline Other items (net) & 6.8 & -0.4 & -4.1 & 0.8 & -0.4 & 0.0 \\
\hline \multicolumn{7}{|l|}{ Memorandum item: } \\
\hline Income velocity $2 /$ & 1.4 & 1.4 & 1.4 & 1.4 & 1.4 & 1.4 \\
\hline
\end{tabular}

Sources: ECCB; Ministry of Finance and Planning; and IMF staff estimates and projections.

1 / Including resident foreign currency deposits.

2/ Nominal GDP at market prices divided by liabilities to the private sector. 
Table 6. St. Vincent and the Grenadines: Baseline Scenario, Medium-Term Projections, 2014-2023

(In percent of GDP, unless otherwise specified)

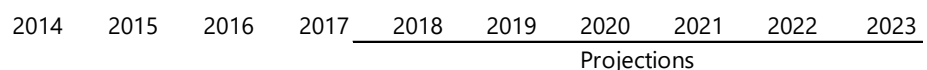

Projections

\section{Output and prices}

Real GDP growth at factor cost (in percent)

Nominal GDP

Consumer Price Index, end-of-period (percent change)

Consumer Price Index, average (percent change)

Central government finances

Total revenue and grants

Of which:

Tax revenue

Taxes on income and profits

Taxes on property

Taxes on international trade

Taxes on domestic transactions

Grants

Total expenditure and net lending

Of which:

Wages and salaries 1/

Transfers and subsidies

Capital expenditure

Overall balance

Of which: Primary balance

Financing

Net external financing

Net domestic financing

Other

\section{Gross public sector debt 2/}

\section{External secto}

Current account balance

Gross public sector external debt (end of period)

External public debt service

(In percent of exports of goods and services)

\begin{tabular}{|c|c|c|c|c|c|c|c|c|c|}
\hline 0.2 & 0.8 & 0.8 & 0.7 & 2.0 & 2.3 & 2.4 & 2.3 & 2.3 & 2.3 \\
\hline 0.9 & 3.8 & 2.0 & 1.9 & 5.2 & 4.6 & 4.5 & 4.3 & 4.4 & 4.4 \\
\hline 0.1 & -2.1 & 1.0 & 3.0 & 2.0 & 2.0 & 2.0 & 2.0 & 2.0 & 2.0 \\
\hline 0.2 & -1.7 & -0.2 & 2.2 & 2.4 & 2.0 & 2.0 & 2.0 & 2.0 & 2.0 \\
\hline 29.3 & 27.9 & 29.8 & 30.3 & 27.8 & 28.2 & 28.4 & 28.4 & 28.4 & 28.4 \\
\hline 24.0 & 23.6 & 25.5 & 25.7 & 24.1 & 24.4 & 24.4 & 24.4 & 24.4 & 24.4 \\
\hline 7.1 & 6.4 & 7.5 & 7.1 & 6.5 & 6.6 & 6.6 & 6.6 & 6.6 & 6.6 \\
\hline 0.2 & 0.2 & 0.2 & 0.2 & 0.2 & 0.2 & 0.2 & 0.2 & 0.2 & 0.2 \\
\hline 9.5 & 9.8 & 10.4 & 10.3 & 10.2 & 10.5 & 10.5 & 10.5 & 10.5 & 10.5 \\
\hline 7.1 & 7.3 & 7.4 & 8.1 & 7.2 & 7.2 & 7.2 & 7.2 & 7.2 & 7.2 \\
\hline 2.0 & 1.2 & 1.2 & 2.1 & 1.4 & 1.4 & 1.4 & 1.4 & 1.4 & 1.4 \\
\hline 32.3 & 30.0 & 28.7 & 30.8 & 29.8 & 29.9 & 29.9 & 29.8 & 29.7 & 29.7 \\
\hline 12.6 & 12.6 & 13.2 & 13.3 & 12.8 & 12.7 & 12.5 & 12.5 & 12.4 & 12.3 \\
\hline 7.2 & 6.8 & 6.4 & 7.4 & 7.4 & 7.3 & 7.3 & 7.4 & 7.4 & 7.5 \\
\hline 6.4 & 4.9 & 3.8 & 4.1 & 3.6 & 3.9 & 3.9 & 3.9 & 3.9 & 3.9 \\
\hline-3.0 & -2.1 & 1.1 & -0.5 & -2.0 & -1.7 & -1.5 & -1.4 & -1.3 & -1.3 \\
\hline-0.7 & 0.1 & 3.2 & 1.9 & 0.6 & 0.8 & 1.0 & 1.0 & 1.1 & 1.2 \\
\hline 3.0 & 3.5 & -1.1 & 0.5 & 2.0 & 1.7 & 1.5 & 1.4 & 1.3 & 1.3 \\
\hline 4.6 & 2.2 & -0.5 & -1.7 & 0.0 & 2.9 & 1.6 & 0.0 & 0.2 & 0.4 \\
\hline-3.1 & 3.1 & 1.1 & 4.2 & 3.3 & -0.6 & 0.5 & 2.0 & 1.7 & 1.1 \\
\hline 1.5 & -1.8 & -1.7 & -2.0 & -1.3 & -0.6 & -0.6 & -0.6 & -0.6 & -0.2 \\
\hline 79.4 & 79.4 & 82.8 & 74.2 & 73.1 & 71.4 & 69.7 & 68.1 & 66.7 & 65.6 \\
\hline 25.8 & -14.5 & -15.2 & -17.2 & -15.9 & -15.0 & -14.1 & -13.2 & -12.4 & -11.5 \\
\hline 45.5 & 46.4 & 56.7 & 47.4 & 44.8 & 45.0 & 43.9 & 41.5 & 39.1 & 36.9 \\
\hline 12.6 & 10.3 & 27.7 & 51.0 & 28.4 & 15.2 & 14.3 & 13.0 & 14.1 & 13.8 \\
\hline
\end{tabular}

Sources: ECCB; Ministry of Finance and Planning; and IMF staff estimates and projections.

1/ Wages and salaries including social security contributions, commissions, rewards, allowances, and incentives.

2/ Includes debt of central government and state-owned enterprises. 
Table 7. St. Vincent and the Grenadines: External and Financial Vulnerability Indicators, 2014-2017

(Annual percentage changes, unless otherwise specified)

\begin{tabular}{|c|c|c|c|c|}
\hline & 2014 & 2015 & 2016 & 2017 \\
\hline \multicolumn{5}{|l|}{ External indicators } \\
\hline Merchandise exports & -9.0 & -6.7 & -7.0 & -13.8 \\
\hline Merchandise imports & -2.1 & -7.8 & 0.1 & -1.6 \\
\hline Terms of trade deterioration (-) & -1.8 & -2.6 & -2.1 & -1.6 \\
\hline Tourism earnings & 89.7 & 18.2 & 4.5 & -2.1 \\
\hline Current account balance (in percent of GDP) & -25.8 & -14.5 & -15.2 & -17.2 \\
\hline Official net imputed reserves (in millions of U.S. dollars) & 156.1 & 164.7 & 191.2 & 180.4 \\
\hline Commercial banks' net foreign assets (in millions of U.S. dollars) & 32.1 & 32.3 & 53.9 & 50.2 \\
\hline External public debt (in percent of GDP) & 45.5 & 46.4 & 56.7 & 47.4 \\
\hline External debt service (in percent of exports of goods and services) & 12.6 & 10.3 & 27.7 & 51.0 \\
\hline Of which: Interest & 3.2 & 2.6 & 2.4 & 2.4 \\
\hline Nominal exchange rate (EC\$ per US\$, end period) & 2.7 & 2.7 & 2.7 & 2.7 \\
\hline Real effective exchange rate depreciation (-), end period & 0.0 & 11.7 & 1.0 & -1.8 \\
\hline \multicolumn{5}{|l|}{ Financial indicators } \\
\hline Broad money & 9.5 & 4.8 & 3.0 & 1.2 \\
\hline Credit to the private sector & -0.2 & 2.4 & 1.3 & 1.6 \\
\hline \multicolumn{5}{|l|}{ Banking system financial stability indicators (in percent) } \\
\hline Regulatory capital to risk-weighted assets & 16.0 & 20.6 & 20.1 & 19.9 \\
\hline Nonperforming loans net of provisions to capital & 52.7 & 42.5 & 46.9 & 46.7 \\
\hline Nonperforming loans to total loans & 10.0 & 8.7 & 9.2 & 9.0 \\
\hline General government loans to total loans & 9.2 & 8.4 & 8.5 & 8.6 \\
\hline Return on assets & -0.2 & 0.8 & 0.7 & 0.7 \\
\hline Liquid assets to total assets & 37.6 & 38.2 & 40.0 & 38.0 \\
\hline Spread between reference lending and deposit rates & 6.8 & 7.3 & 7.3 & 7.3 \\
\hline Total loans to total deposits & 68.1 & 67.9 & 66.8 & 68.8 \\
\hline Foreign-currency-denominated liabilities to total liabilities & 7.0 & 8.3 & 7.5 & 7.0 \\
\hline
\end{tabular}

Sources: ECCB; Ministry of Finance and Planning; and IMF staff estimates and projections. 


\section{Annex I. Implementation of Previous Key Staff Advice}

\begin{tabular}{|c|c|}
\hline 2017 Article IV Recommendations & Status \\
\hline \multicolumn{2}{|c|}{ Fiscal Policy } \\
\hline $\begin{array}{l}\text { Broaden the tax base by streamlining tax concessions and } \\
\text { exemptions. }\end{array}$ & Under consideration. \\
\hline Continue restraining the wage bill & $\begin{array}{l}\text { Ongoing. Since January 2016, there has been no base salary } \\
\text { increase. }\end{array}$ \\
\hline Curb the growth of public pensions & $\begin{array}{l}\text { Under consideration. The government is preparing a } \\
\text { pension reform strategy. }\end{array}$ \\
\hline $\begin{array}{l}\text { Preparing and implementing legislation on tax } \\
\text { administration procedures, with a provision for assigning a } \\
\text { Tax Identification Number (TIN) to each taxpayer. }\end{array}$ & $\begin{array}{l}\text { In progress. The Tax Administration and Procedures Act is to } \\
\text { be tabled in the parliament in early } 2019 \text {. }\end{array}$ \\
\hline $\begin{array}{l}\text { Fiscal reporting should be expanded to cover the widest } \\
\text { possible fiscal perimeter beyond the focus on the central } \\
\text { government budget, and present fiscal risks explicitly. }\end{array}$ & Not implemented. \\
\hline $\begin{array}{l}\text { A plan for clearing existing arears should be articulated and } \\
\text { executed. }\end{array}$ & In progress. \\
\hline $\begin{array}{l}\text { Strengthen the capacities of the Ministry of Finance in } \\
\text { internal audit, financial management information systems, } \\
\text { and cash management }\end{array}$ & $\begin{array}{l}\text { In progress. A Cash Management Committee has been } \\
\text { established. }\end{array}$ \\
\hline \multicolumn{2}{|c|}{ Policies to Address Natural Disasters and Climate Change } \\
\hline Increase resources for the contingencies fund & $\begin{array}{l}\text { Implemented. The government implemented a new climate } \\
\text { resilience levy in October } 2018 .\end{array}$ \\
\hline Promote more resilient infrastructure & $\begin{array}{l}\text { In progress. The new international airport is resilient to } \\
\text { natural hazards. Several resilient infrastructure projects, } \\
\text { including slope stabilization, rivers defense, and coastal } \\
\text { protection, are underway. }\end{array}$ \\
\hline $\begin{array}{l}\text { Strengthen and enforce the Building Code and Physical } \\
\text { Planning Law, enhance the powers of the NEMO, and } \\
\text { articulate and implement a strategy to rezone areas and } \\
\text { relocate populations deemed at risk. }\end{array}$ & Limited progress. \\
\hline \multicolumn{2}{|c|}{ Structural Policies } \\
\hline Move ahead with the preparation of the Investment Act & Limited progress. \\
\hline $\begin{array}{l}\text { Develop the vocational training program, and enhance } \\
\text { labor market flexibility }\end{array}$ & In progress. \\
\hline Improve land title registration, and improve access to credit & Limited progress. \\
\hline $\begin{array}{l}\text { Reorient the agriculture sector from subsistence to } \\
\text { agribusiness and strengthen its link to tourism }\end{array}$ & In progress. \\
\hline
\end{tabular}




\section{Financial Sector Policies}

\begin{tabular}{|l|l|}
\hline \multicolumn{1}{|c|}{2017 Article IV Recommendations } & \multicolumn{1}{c|}{ Status } \\
\hline Approve the FSA regulations & $\begin{array}{l}\text { In progress. Draft FSA regulations have been sent to } \\
\text { Attorney General Office for review. }\end{array}$ \\
\hline $\begin{array}{l}\text { Issue regulations on non-profit organizations to address } \\
\text { AML/CFT shortcomings }\end{array}$ & In progress. Draft FSA regulations are under preparation. \\
\hline $\begin{array}{l}\text { Continue preparations towards the } 2018 \text { implementation of } \\
\text { the Organization of Eastern Caribbean States Harmonized } \\
\text { Credit Reporting Act }\end{array}$ & $\begin{array}{l}\text { Implemented. St. Vincent authorities have completed their } \\
\text { work. }\end{array}$ \\
\hline
\end{tabular}




\section{Annex II. External Sector Assessment and Competitiveness}

St. Vincent and the Grenadines' current account deficit remains substantial, despite some improvements in recent years. The external position remains weaker than implied by medium-term fundamentals and desirable policies. Implementing fiscal consolidation and structural reforms to strengthen St. Vincent and the Grenadines' external competitiveness would help ensure external balance sustainability.

\section{The external position weakened slightly} in 2017. ${ }^{1}$ Preliminary estimates by the ECCB suggest that the current account deficit widened to 17.2 percent of GDP in 2017, up from 15.2 percent of GDP in 2016. However, the current account deficit in recent years is smaller than in the past.

- The current account deficit widened to over 30 percent of GDP in 2008, when construction of the Argyle International Airport began, and imports of construction materials increased. Higher current account deficits in 2008-2014 also reflected increased fuel imports (due to higher global oil prices), and increased imports of construction materials for rehabilitation and reconstruction projects following severe natural disasters (e.g., floods in 2013).

- In 2015-2017, the current account deficit halved to around 14-17 percent of GDP. The reduced import bills (in part reflecting the completion of the airport) contributed to lowering the trade balance deficit. The increased receipts from tourists and net income inflows also narrowed the current account deficit.

\section{The real effective exchange rate remains} above historical averages. Along with the appreciation of the U.S. dollar, St. Vincent and the Grenadines' real effective exchange rate index (calculated by including all IMF members) increased by about 18 percent between mid-2014 and end-2016. The appreciation pressures have since eased, but only temporarily, as the real effective rate has begun to rise again since the beginning of 2018 , together with the U.S. dollar. The adjusted real effective exchange index (calculated by including only the U.S., Canada, and the U.K., which are St. Vincent and the Grenadines' most critical tourist source economies) has also been on a rising trend, although the adjusted index is less volatile.

\footnotetext{
${ }^{1}$ The Eastern Caribbean Central Bank (ECCB) has revised the external sector statistics for 2014 onwards using the BPM6 methodology, which incorporated updated tourist expenditure surveys, and a wider coverage of offshore universities and their student population.
} 
3. With large current account deficits in the past years, net external liabilities are sizable. The net international investment position reached a deficit of over 150 percent of GDP in 2016. It widened further in 2017 to 168 percent of GDP. Over two-thirds of external liabilities are in the form of foreign direct investment.

\section{St. Vincent and the Grenadines'} imputed share of net international reserves held at the ECCB fell slightly in 2017. The stock of imputed reserves declined from 25 percent of GDP in 2016 to 23 percent of GDP in 2017. Nevertheless, the import cover ratio remained more than seven months, well above the benchmark of three months.

\section{EBA-lite assessment}

\section{IMF's EBA-lite models suggest an overvaluation of the exchange rate between 5 and 12 percent.}

- Current Account Model. The cyclicallyadjusted current account balance is estimated at -17.4 percent of GDP in 2017, while the cyclically-adjusted current account norm (the level consistent with medium-term fundamentals and desirable policies) was -13.7 percent of GDP. This suggests a current account gap of -3.8 percent of GDP, of which 0.2 percent of GDP was attributed to the policy gaps (which include both domestic and world policy gaps) and -4 percent of GDP to the residual. The domestic component of the policy gap ( -0.5 percent of GDP) was mostly due to a higher than desirable level of St. Vincent and the Grenadines' fiscal deficit in 2017. The estimated current account gap implies an exchange rate overvaluation of about 12 percent in 2017.

- Index-REER model. This approach indicates an exchange rate overvaluation of about 5 percent in 2017.
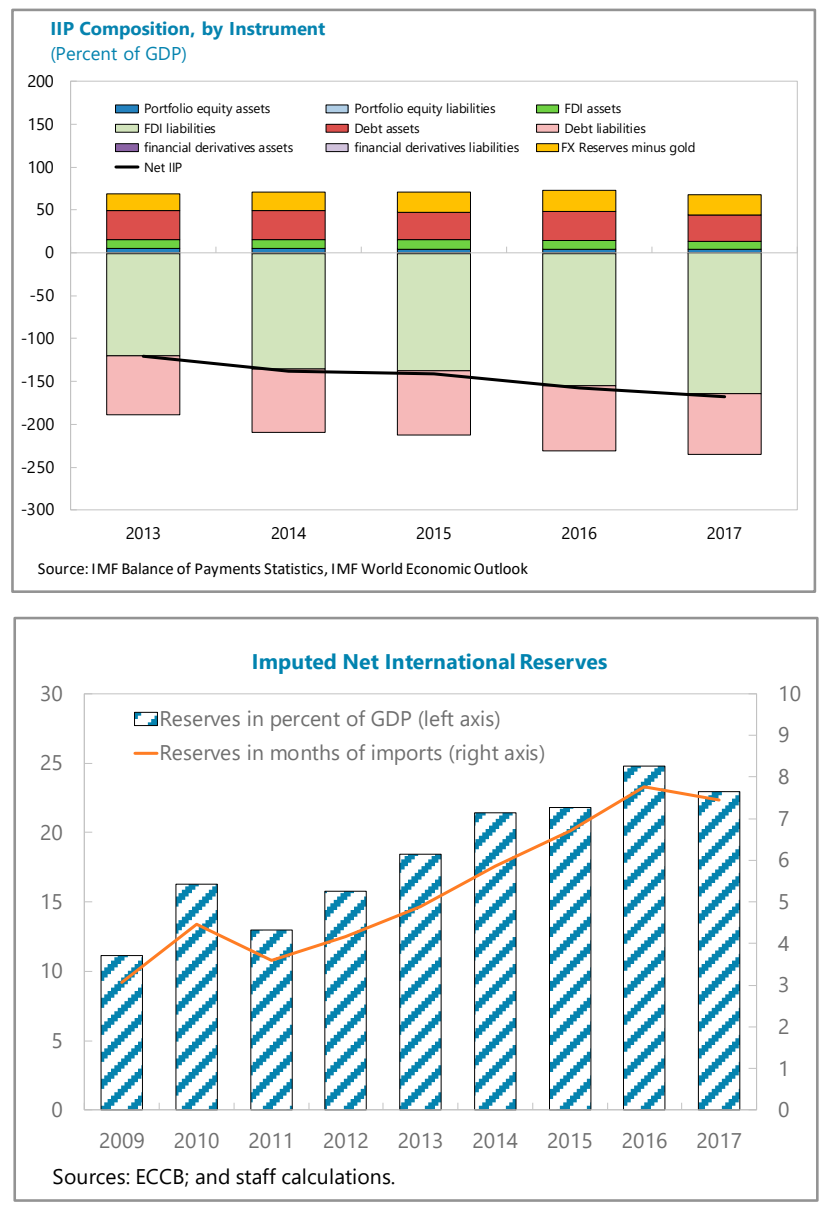

Current Account and Real Exchange Rate Assessments

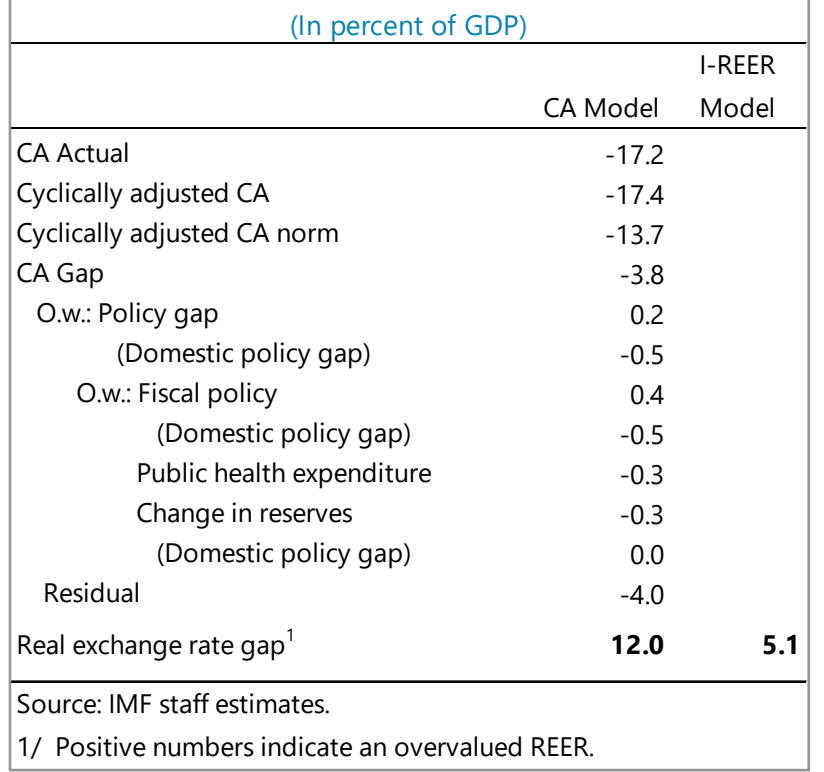

1/ Positive numbers indicate an overvalued REER. 
- External Sustainability model. To stabilize the international investment position at its 2017 level (-168 percent of GDP), the required level of the current account balance (norm) was 12.2 percent of GDP. This is higher than the actual current account deficit in $2017(-17.2$ percent of GDP) but slightly lower than the projected current account deficit in $2023(-11.5$ percent of GDP). Under the baseline medium-term fiscal scenario, public external debt is assumed to be reduced by 18.2 percentage points of GDP in the medium term. This implies, other things equal, an improvement of the international investment position to -149.7 percent of GDP, raising the current account norm to -11.5 percent of GDP. Should this be done by 2030, the current account norm would be further raised to -10.4 percent of GDP, pointing to an exchange rate overvaluation of about 3 percent.

\begin{tabular}{|c|c|c|c|c|c|c|}
\hline \multicolumn{7}{|c|}{ External Sustainability Results } \\
\hline & & $\begin{array}{r}\text { CA norm } \\
\text { (\% of } \\
\text { GDP) }\end{array}$ & $\begin{array}{r}2017 \text { CA } \\
\text { ( } \% \text { of } \\
\text { GDP) }\end{array}$ & $\begin{array}{r}2023 \text { CA proj. } \\
\text { (\% of GDP) }\end{array}$ & CA gap & gap \\
\hline Scenario 1: Stabilizing net IIP at & $-168.0 \%$ of GDP & -12.2 & -17.2 & -11.5 & 0.8 & -2.5 \\
\hline Scenario 2: Stabilizing net IIP at & $-149.7 \%$ of GDP & -11.5 & -17.2 & -11.5 & 0.0 & 0.0 \\
\hline Scenario 3: Reaching net IIP at & $-149.7 \%$ of GDP in 2030 & -10.4 & -17.2 & -11.5 & -1.0 & 3.2 \\
\hline
\end{tabular}

6. Overall assessment. All these results suggest that St. Vincent and the Grenadines' external position is weaker than its level consistent with medium-term fundamentals and desirable policy settings.

\section{Policy Implications}

\section{The external position is expected to improve over the medium term. New flight} connections at the new airport are anticipated to increase tourist arrivals and investment in hotels and resort facilities. Furthermore, with the improved connectivity and air cargo capacity, exportoriented businesses would grow faster, contributing to bolstering external competitiveness. The government's ongoing initiatives to boost agriculture production and promote geothermal and renewable energies would also contribute to reducing the country's import dependency on necessity goods (e.g., fuels and foods). However, to fully reap the benefits of the enhanced connectivity, efforts need to continue to improve the investment and business climate by implementing structural reforms. Fiscal consolidation should continue vigorously to ensure macro-fiscal stability in the medium term. 
Annex III. Risk Assessment Matrix ${ }^{1}$

\begin{tabular}{|c|c|c|c|c|}
\hline \multirow[b]{2}{*}{ Source of risk } & \multirow{2}{*}{$\begin{array}{l}\text { Risk } \\
\text { likelihood }\end{array}$} & \multicolumn{2}{|r|}{ Impact } & \multirow[b]{2}{*}{ Policy response } \\
\hline & & $\begin{array}{l}\text { Size (time } \\
\text { horizon) }\end{array}$ & Channels & \\
\hline \multicolumn{5}{|l|}{ Downside } \\
\hline $\begin{array}{l}\text { Sharp tightening of global financial } \\
\text { conditions }\end{array}$ & High & $\begin{array}{l}\text { Medium } \\
\text { (ST) }\end{array}$ & $\begin{array}{l}\text { Increase external financing } \\
\text { costs }\end{array}$ & $\begin{array}{l}\text { Continue fiscal consolidation. Adopt a } \\
\text { medium-term fiscal framework to } \\
\text { improve fiscal credibility. }\end{array}$ \\
\hline $\begin{array}{l}\text { Weaker than expected global } \\
\text { growth. Especially in the U.S. (most } \\
\text { important tourism source } \\
\text { economy), as capacity constraints } \\
\text { become more binding and the } \\
\text { economy pushes further through } \\
\text { full employment, the risks of a } \\
\text { sharper-than expected slowdown } \\
\text { increase }\end{array}$ & Medium & $\begin{array}{l}\text { Medium } \\
\text { (MT) }\end{array}$ & $\begin{array}{l}\text { Reduce tourist arrivals, } \\
\text { negatively affecting } \\
\text { tourism-related activity }\end{array}$ & $\begin{array}{l}\text { Strengthen competitiveness by } \\
\text { implementing structural reforms. } \\
\text { Diversify the economy and tourism base. }\end{array}$ \\
\hline $\begin{array}{l}\text { Sizable deviations from baseline } \\
\text { energy risks }\end{array}$ & High & $\begin{array}{l}\text { Low/ } \\
\text { Medium } \\
\text { (ST.MT) }\end{array}$ & $\begin{array}{l}\text { An increase in oil prices by } \\
10 \text { percent would increase } \\
\text { CPI by about } 0.5 \text { percent } \\
\text { and worsen the current } \\
\text { account by } 0.1-0.2 \\
\text { percentage points of GDP. }\end{array}$ & $\begin{array}{l}\text { Advance on the geothermal energy } \\
\text { project and diversify the energy matrix. } \\
\text { Continue to allow for the full pass- } \\
\text { through of prices to minimize the impact } \\
\text { on public finances. }\end{array}$ \\
\hline More severe natural disasters & High & $\begin{array}{l}\text { High (ST, } \\
\text { MT) }\end{array}$ & $\begin{array}{l}\text { Reduce growth and worsen } \\
\text { fiscal and external positions }\end{array}$ & $\begin{array}{l}\text { Capitalize the contingency fund and } \\
\text { allocate expenditure reserves for } \\
\text { emergency operations, and expand the } \\
\text { coverage of disaster insurance, especially } \\
\text { against floods. }\end{array}$ \\
\hline Financial sector risks materialize & Medium & $\begin{array}{l}\text { Low (ST, } \\
\text { MT) }\end{array}$ & $\begin{array}{l}\text { A confidence shock could } \\
\text { trigger deposit outflows, } \\
\text { leading to financial } \\
\text { instability }\end{array}$ & $\begin{array}{l}\text { Continue to strengthen financial } \\
\text { regulation and supervision, and develop } \\
\text { a crisis management framework }\end{array}$ \\
\hline $\begin{array}{l}\text { Loss of correspondent banking } \\
\text { services relationships }\end{array}$ & Medium & $\begin{array}{l}\text { Medium } \\
\text { (ST, MT) }\end{array}$ & $\begin{array}{l}\text { Costs and time to settle } \\
\text { transactions rise, affecting } \\
\text { trade finance and } \\
\text { remittance inflows }\end{array}$ & $\begin{array}{l}\text { Conduct National Risk Assessment } \\
\text { exercises and strengthen international tax } \\
\text { cooperation frameworks }\end{array}$ \\
\hline \multicolumn{5}{|l|}{ Upside } \\
\hline $\begin{array}{l}\text { Tourist arrivals and more direct } \\
\text { flights from major cities in the U.S. } \\
\text { and Canada. }\end{array}$ & Medium & $\begin{array}{l}\text { Medium/ } \\
\text { High (ST, } \\
\text { MT) }\end{array}$ & $\begin{array}{l}\text { Boost tourism-related } \\
\text { activities }\end{array}$ & $\begin{array}{l}\text { To fully reap the benefits of the } \\
\text { enhanced connectivity, efforts need to } \\
\text { continue to improve the investment and } \\
\text { business climate by implementing } \\
\text { structural reform agenda }\end{array}$ \\
\hline Stronger investor interest & Medium & $\begin{array}{l}\text { Medium/ } \\
\text { High (ST, } \\
\text { MT) }\end{array}$ & $\begin{array}{l}\text { Boost investment in hotels } \\
\text { and resort developments }\end{array}$ & Same as above \\
\hline
\end{tabular}

\footnotetext{
${ }^{1}$ The Risk Assessment Matrix (RAM) shows events that could materially alter the baseline path (the scenario most likely to materialize in the view of IMF staff). The relative likelihood is the staff's subjective assessment of the risks surrounding the baseline ("low" is meant to indicate a probability below 10 percent, "medium" a probability between 10 and 30 percent, and "high" a probability between 30 and 50 percent). The RAM reflects staff views on the source of risks and overall level of concern as of the time of discussions with the authorities. Non-mutually exclusive risks may interact and materialize jointly. "Short term (ST)" and "medium term (MT)" are meant to indicate that the risk could materialize within 1 year and 3 years, respectively.
} 


\section{Appendix I. The New International Airport: A Bid for Growth}

1. On February 14, 2017, the Argyle International Airport opened, replacing the much smaller ET Joshua Airport. The new airport can handle about 1.4 million passengers per year, more than four times the capacity of the old airport. With the runway length of 9,000 feet, it can accommodate a jet airplane as big as the Boeing 747-400.

\begin{tabular}{|c|c|c|}
\hline \multicolumn{3}{|c|}{ Comparisons of Old and New Airports } \\
\hline & $\begin{array}{c}\text { Old ET Joshua } \\
\text { Airport }\end{array}$ & $\begin{array}{c}\text { New Argyle } \\
\text { Airport }\end{array}$ \\
\hline Passenger capacity & 0.28 mill. per year & 1.4 mill. per year \\
\hline Runway length & $\begin{array}{c}4,595 \mathrm{ft} \text { long by } 150 \\
\mathrm{ft} \text { wide }\end{array}$ & $\begin{array}{c}9,000 \mathrm{ft} \text { long by } \\
150 \mathrm{ft} \text { wide }\end{array}$ \\
\hline Largest aircraft capacity & $\begin{array}{c}\text { ATR 42-600, ATR 72- } \\
600\end{array}$ & Boeing 747-400s \\
\hline
\end{tabular}

2. In 2005, the government officially announced its plan to build a new airport, which aroused some controversy. First, because St. Vincent is a mountainous island, it was difficult to find flat land, and a flat land was created by levelling out mountains. Second, the construction costs were estimated significantly high at EC $\$ 700$ million (about 37 percent of 2008 GDP), and the authorities faced difficulties in securing financing, in part due to tightened global financial conditions following the 2008 global financial crisis. Nonetheless, the authorities managed to secure grants (including in-kind) and concessional loans (with the effective average interest rate estimated at below 1 percent) from both bilateral and multilateral lenders. The construction of the airport began in August 2008 and was scheduled to be completed in 2011. But due to the above-mentioned challenges, the construction was delayed by about 6 years.

\section{Nearly two years after its} opening, the airport is already paying dividends. Several major international airlines have begun direct services from New York, Miami, and Toronto. With the improved connectivity, stayover arrivals have recovered to 5 percent growth (year-on-year) in the first eight months of 2018, from -4.3 percent in 2017. ${ }^{1}$ The airport also includes a modern cargo terminal with a large warehouse space

\begin{tabular}{|c|c|c|c|}
\hline \multicolumn{3}{|c|}{ Major New Direct Flights from the U.S. and Canada } \\
\hline Beginning in & New Direct Flight & From & Frequency \\
\hline December 2017 & Air Canada Rouge & Toronto & $\begin{array}{c}\text { Weekly (Thursday), } \\
\text { year round }\end{array}$ \\
\hline March, 2018 & Caribbean Airlines & New York & $\begin{array}{c}\text { Weekly } \\
\text { (Wednesday) year } \\
\text { round }\end{array}$ \\
\hline December, 2018 & Air Canada Rouge & Toronto & $\begin{array}{c}\text { Weekly (Sunday), } \\
\text { seasonal from } \\
\text { December to April }\end{array}$ \\
\hline December, 2018 & American Airlines & Miami & $\begin{array}{c}\text { Weekly (Saturday), } \\
\text { year round }\end{array}$ \\
\hline
\end{tabular}
and cold storage, which would support exports of agriculture and fish products. The Ministry of Agriculture estimates that fish and lobster exports grew by more than 50 percent (year-on-year) in the second quarter of 2018.

\footnotetext{
${ }^{1}$ Culiuc (2014) shows that tourism flows respond strongly to changes in the destination country's real exchange rate. Tourism to small islands, however, is less sensitive to changes in the country's real exchange rate, but more susceptible to the introduction/removal of direct flights.
} 


\section{Tourism will continue to be a key} driver of economic growth in St. Vincent and the Grenadines. Tourism has a direct impact on tourism-related activities (including hotels, restaurants, transport, and retail trade). ${ }^{2}$ It would also have indirect spillovers effects on the economy as a whole: for example, prospects of rising tourism arrivals would encourage investment in hotels and resort facilities. Staff estimates that a 1 percent growth in tourist stayover arrivals is associated with a 1 percent increase in real GDP in the long-run.

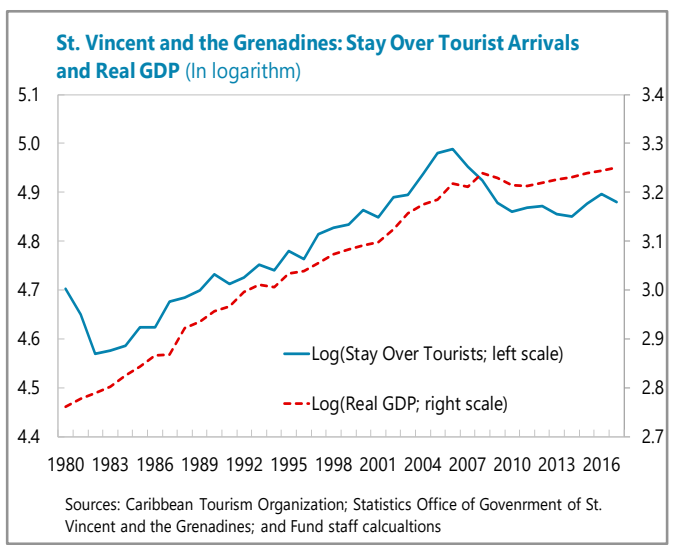

\section{Nonetheless, tourism growth should not be taken for granted, and a strategy} to leverage tourism to boost potential growth will be needed. Hotel capacity (currently, about 1,900 rooms) needs to be increased over the medium term, while tourism industry needs to constantly adapt to the changing preferences and needs of tourists. Meanwhile, the government should continue to find a way to diversify the economy, possibly by linking tourism to the local economy, for example, agriculture and light manufacturing (Caribbean Development Bank, 2017). Further opportunities for regional collaboration should be explored. This includes concerted efforts to improve transportation links and the standardization of immigration and customs procedures across the region. Finally, the private sector should have an important role to play in driving innovation and enhancing competitiveness in the tourism sector. In this light, the government's continued efforts to improve the business and investment environment is critical.

\footnotetext{
${ }^{2}$ In the National Accounts, these tourism sectors, as well as the wholesale sector (which cannot be stripped out due to data limitation), account for about 30 percent of GDP.
} 


\section{References}

Caribbean Development Bank, 2017, "Tourism Industry Reform: Strategies for Enhanced Economic Impact."

Culiuc, A., 2014, "Determinants of International Tourism," IMF Working Paper, 14/82.

St. Vincent and the Grenadines Ministry of Agriculture and Statistical Office. 


\section{Appendix II. Disaster Risk Financing Strategies and Contingency Fund}

1. St. Vincent and the Grenadines is vulnerable to natural disasters including floods, landslides, and earthquakes.

Fortunately, St. Vincent and the Grenadines has not been hit by huge hurricanes (like Hurricanes Irma and Maria in 2017, causing major disasters in Dominica) over the past few decades. However, the economy has been hit by severe rains and high winds resulting in floods and landslides, several times in recent years. For example, during December $24^{\text {th }}$ and $25^{\text {th }}, 2013$, a

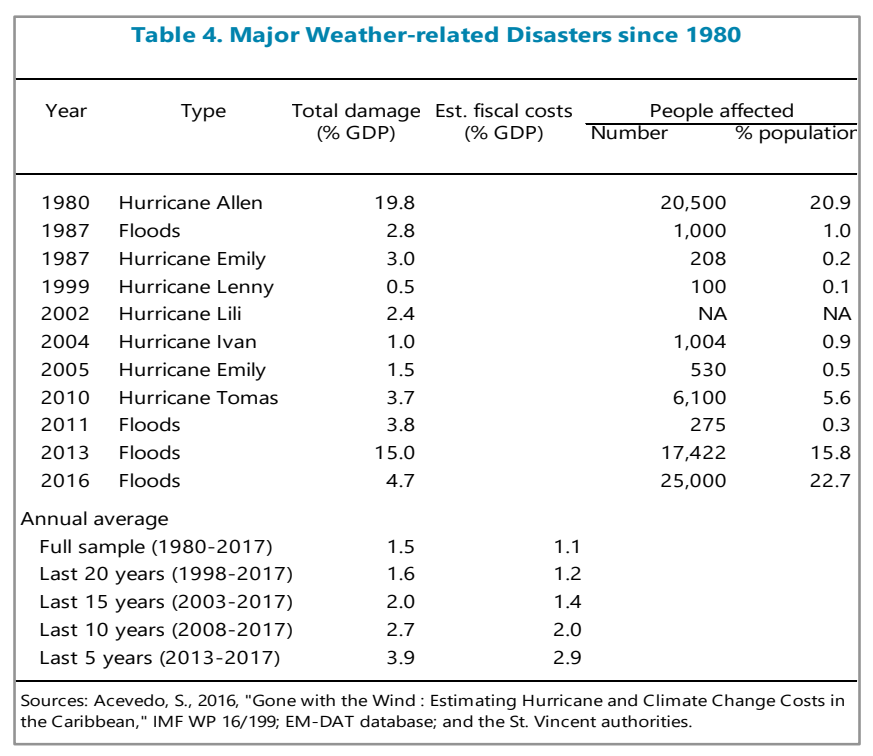
tropical trough system produced heavy rains, causing flush floods and landslides. This took the lives of a few people and damaged roads, electricity, and water infrastructure, housing, public and private buildings (estimated at about 15 percent of GDP).

\section{The frequency and severity of natural disasters seems to have intensified in} recent years. The annual average of total natural disaster damages is estimated at 1.5 percent of GDP for the period 1980-2017. Taking more recent and shorter sample periods, natural disaster damages averaged 2 percent of GDP for the last 15 years and 2.7 percent of GDP for the last 10 years.

\section{To secure financing for disaster costs, the government created the Contingencies}

Fund in 2017. The primary purpose of the Contingency Fund is to provide self-insurance to cover emergency relief and reconstruction in the event of natural disasters. The fund has dedicated financing sources: the government increased the standard VAT rate from 15 to 16 percent (and the VAT for tourism sector from 10 to 11 percent) effective May 2017 and introduced a Climate Resilience Levy (paid by all stay-over visitors in hotels, apartments, and short-term rentals at EC\$8 per night) effective October 2018. Staff estimates that these measures would generate about 0.7 percent of GDP annually. The fund is expected to grow only gradually: assuming no natural disasters, staff projects that the size of the fund would reach 1.4 percent of GDP by the end of 2019. The fund complements insurance coverage through the Caribbean Catastrophe Risk Insurance Facility (CCRIF) in protecting public finances from large and volatile expenditures associated with natural disasters.

4. While the establishment of the Contingency Fund is welcome, a robust legislation framework is necessary to provide safeguards for effective governance and operational arrangements. The legislation should (i) provide clearly the legal form and structure of the fund and its relationship with other state bodies (including the MOF); (ii) ensure consistency 
with the broader public financial management framework governing budgetary processes (especially, the Contingency Fund's operations should be consolidated with budget reports to allow for a proper assessment of the government's overall fiscal position); (iii) support its effective operation and the achievement of its stated policy objective(s), which should be economic and financial in nature; and (iv) promote effective accountability and transparency. Key features which could be specified in the legislation framework are summarized in Appendix II Box 1.

\section{Box 1. Key Features to be Articulated in Legislation framework for the Contingency}

\section{Fund}

- Objectives. To avoid the Contingency Fund being used for events different from natural disasters, the legislation should clearly stipulate that the objective is to finance emergencies and reconstruction efforts in the event of natural disasters.

- Triggers for withdrawals. Trigger events should also be defined (such as a declaration of a disaster emergency by the government).

- Size. The size should be determined by considering (i) expected damages, (ii) likely available support from the international community, (iii) ability to borrow in an emergency, and (iv) opportunity costs for building up buffers. Given opportunity costs, the fund should not get too large because (i) its primary purpose is to "buy time" by covering immediate expenses during which time longer-term financing can be arranged, and (ii) a large fund will generate pressures to tap it for other purposes.

- Investment strategy. It is important that the fund should retain a relatively high level of liquidity to deal with the urgency of disbursement and have a diversified portfolio.

- Accountability and reporting. While some flexibility may be needed (e.g., procurement processes) to provide emergency relief when natural disasters occur, releases of funds need to comply with Public Financial Management regulations. The fund balance should appear in financial statements, and drawdowns from the fund should appear in the budget execution reports. The Audit Office should also examine and audit the financial statements of the Contingency Fund and publish its reports.

- Governance structure. The organizational structure should clearly distinguish decision-making by the owner (i.e., the government) and operational implementation.

\section{The authorities should also review whether the current level of insurance}

coverage is adequate. For example, in the 2016 floods, the amount of the insurance payout was only EC $\$ 0.8$ million ( 0.03 percent of GDP), as the government chose to keep premium costs low, given limited fiscal space. While self-insurance through the Contingency Fund can help reduce funding uncertainty when disasters hit, its size is expected to remain small in the near future. As a risk transfer tool, insurance would offer an additional layer of projection, especially against a disaster risk with low frequency but high severity. In this context, consideration should be given to expand the coverage of disaster insurance through CCRIF and reduce the government's contingent liabilities, especially against floods. 


\section{INTERNATIONAL MONETARY FUND}

\section{ST. VINCENT AND THE GRENADINES}

STAFF REPORT FOR THE 2018 ARTICLE IV CONSULTATIONINFORMATIONAL ANNEX

Prepared By The Western Hemisphere Department

\section{CONTENTS}

FUND RELATIONS $\underline{\mathbf{2}}$

RELATIONS WITH THE WORLD BANK GROUP $\underline{6}$

RELATIONS WITH THE CARIBBEAN DEVELOPMENT BANK (CDB) $\underline{8}$

STATISTICAL ISSUES $\underline{10}$ 


\section{FUND RELATIONS}

(As of December 31, 2018)

Membership Status:

General Resources Account:

Quota

Fund holdings of currency

Reserve Tranche Position

SDR Department:

Net cumulative allocation

Holdings

Outstanding Purchases and Loans:

RCF Loans

Emergency Assistance $/ 1$

ESF RAC Loan

Latest Financial Arrangements:
Joined: December 28, 1979; Article VIII SDR Million

11.70

11.98

Percent of Quota

100.00

102.38

0.50

4.27

SDR Million

7.91

0.27

SDR Million

Percent of Quota

3.86

0.78

0.37
32.99

6.65

3.19

Percent of

Allocation

100.00

3.38

9
99
65
19

Projected Payments to the Fund ${ }^{2}$

None

\begin{tabular}{lcrrr} 
& \multicolumn{5}{c}{ Forthcoming } \\
\cline { 2 - 5 } & 2019 & 2020 & 2021 & 2022 \\
Principal & 1.82 & 1.08 & 0.87 & 0.42 \\
Charges/Interest & 0.09 & 0.08 & 0.08 & 0.08 \\
Total & 1.91 & 1.16 & 0.96 & 0.50
\end{tabular}

Implementation of HIPC Initiative:

Not Applicable

Implementation of Multilateral Debt Relief Initiative (MDRI): Not Applicable Implementation of Catastrophe Containment and Relief (CCR): Not Applicable

\footnotetext{
${ }^{1}$ Emergency Assistance may include ENDA, EPCA, and RFI.

${ }^{2}$ When a member has overdue financial obligations outstanding for more than three months, the amount of such arrears will be shown in this section.
} 
Exchange Rate Assessment: St. Vincent and the Grenadines is a member of the Eastern Caribbean Currency Union, with the Eastern Caribbean Central Bank (ECCB) as the common central bank, and the Eastern Caribbean dollar as the common currency. Since July 1976, the Eastern Caribbean dollar has been pegged to the U.S. dollar at EC $\$ 2.70$ per U.S. dollar. The exchange rate arrangement is classified as a currency board. St. Vincent and the Grenadines has accepted the obligations of Article VIII, Sections 2(a), 3 and 4, and maintains an exchange system that is free of restrictions on the making of payments and transfers for current international transactions.

Safeguards Assessment: Under the Fund's safeguards policy, the ECCB is subject to a full safeguards assessment on a four-year cycle. An update assessment was completed in April 2016 and found that the ECCB has maintained generally strong controls over its key operations. External audit and financial reporting practices remain sound. The ECCB financial statements are compliant with International Financial Reporting Standards and are published on a timely basis. The internal audit function has since been reformed to align it with leading international practices and oversight was further strengthened by enhancing the financial expertise of the audit committee.

Article IV consultation: St. Vincent and the Grenadines is on a 12-month cycle. The last Article IV consultation was concluded on December 15, 2017 by the Executive Board; Country Report $17 / 400$.

Technical Assistance (TA): TA missions from the Caribbean Regional Technical Assistance Centre (CARTAC), Monetary and Capital Markets Department (MCM), Fiscal Affairs Department (FAD), and Statistics Department (STA) in 2012-2018 are summarized as following.

\begin{tabular}{|c|c|c|c|}
\hline \multicolumn{4}{|c|}{ St. Vincent and the Grenadines: Fund Technical Assistance, 2012-2018 } \\
\hline Department & Areas & Main objectives & Mission dates \\
\hline STA & External sector statistics & $\begin{array}{l}\text { Enhance the compilation of the annual balance } \\
\text { of payments and international investment } \\
\text { position statistics. }\end{array}$ & Sept 17-28, 2018 \\
\hline MCM & $\begin{array}{l}\text { Government securities } \\
\text { market }\end{array}$ & $\begin{array}{l}\text { Develop an investor relations program to } \\
\text { increase the visibility in the regional } \\
\text { government securities market and widen the } \\
\text { investor base. }\end{array}$ & Aug 13-17, 2018 \\
\hline MCM & $\begin{array}{l}\text { Risk-based supervision } \\
\text { framework }\end{array}$ & $\begin{array}{l}\text { Strengthen financial resilience in the insurance } \\
\text { sector, including by developing an insurance } \\
\text { sector stress testing framework. }\end{array}$ & Jun 25-29, 2018 \\
\hline STA & $\begin{array}{l}\text { National accounts } \\
\text { statistics }\end{array}$ & $\begin{array}{l}\text { Review and provide advice on improving and } \\
\text { expanding the national accounts. }\end{array}$ & Jan 22-Feb 2, 2018 \\
\hline FAD & $\begin{array}{l}\text { Medium-term fiscal } \\
\text { framework }\end{array}$ & $\begin{array}{l}\text { Strengthen the medium-term economic and } \\
\text { fiscal outlook statement and better integrate it } \\
\text { into the budget process. }\end{array}$ & Mar 7-15, 2017 \\
\hline
\end{tabular}




\begin{tabular}{|c|c|c|c|}
\hline \multicolumn{4}{|c|}{ St. Vincent and the Grenadines: Fund Technical Assistance, 2012-18 (continued) } \\
\hline Department & Areas & Main objectives & Mission dates \\
\hline FAD & Tax policy & $\begin{array}{l}\text { Review selected issues in tax policy and the } \\
\text { status of the suggestions of previous technical } \\
\text { assistance from FAD, and assess the scope for } \\
\text { further TA. }\end{array}$ & Nov 16-25, 2016 \\
\hline MCM & Credit union supervision & $\begin{array}{l}\text { Help the Financial Services Authority build } \\
\text { analytical capacity for effective credit union } \\
\text { supervision, particularly stress testing and } \\
\text { financial soundness analytical frameworks. }\end{array}$ & Aug 8-12, 2016 \\
\hline STA & $\begin{array}{l}\text { National accounts } \\
\text { statistics }\end{array}$ & $\begin{array}{l}\text { Review and provide advice on improving and } \\
\text { expanding the national accounts, particularly } \\
\text { quarterly constant price GDP by economic } \\
\text { activity. }\end{array}$ & Jun 6-17, 2016 \\
\hline FAD & Expenditure arrears & $\begin{array}{l}\text { Develop a strategy to resolve the existing } \\
\text { expenditure arrears and to prevent the } \\
\text { reoccurrence of new ones. }\end{array}$ & Apr 27- May 10, 2016 \\
\hline FAD & $\begin{array}{l}\text { Cash basis International } \\
\text { Public Accounting } \\
\text { Standards (IPSAS) }\end{array}$ & $\begin{array}{l}\text { Provide technical assistance in adopting cash } \\
\text { basis IPSAS for reporting the financial operations } \\
\text { of the government. }\end{array}$ & Mar 29 -Apr 2, 2016 \\
\hline STA & $\begin{array}{l}\text { National accounts } \\
\text { statistics }\end{array}$ & $\begin{array}{l}\text { Assist with improvements in the annual GDP by } \\
\text { economic activity estimation methodology. }\end{array}$ & Oct 19-30, 2015 \\
\hline FAD & Cash basis IPSAS & $\begin{array}{l}\text { Provide technical assistance in adopting Cash } \\
\text { Basis IPSAS for reporting the financial operations } \\
\text { of the government. }\end{array}$ & Oct 26- Nov 6, 2015 \\
\hline FAD & $\begin{array}{l}\text { Government finance } \\
\text { statistics (GFS) }\end{array}$ & $\begin{array}{l}\text { Assist in implementing the GFS compliant chart } \\
\text { of accounts. }\end{array}$ & Jul 29-Aug 4, 2015 \\
\hline FAD & $\begin{array}{l}\text { Public finance } \\
\text { management (PFM) } \\
\text { reforms }\end{array}$ & $\begin{array}{l}\text { Identify short term PFM reforms as part of the } \\
\text { Fiscal Management in the Caribbean Project. }\end{array}$ & May 26-29, 2015 \\
\hline STA & External sector statistics & $\begin{array}{l}\text { Help survey respondents in recording external } \\
\text { sector statistics, particularly good imports, travel } \\
\text { credits, private transfers and FDI. }\end{array}$ & Feb 2-6, 2015 \\
\hline STA & $\begin{array}{l}\text { National accounts } \\
\text { statistics }\end{array}$ & $\begin{array}{l}\text { Assist the authorities in revising the estimates of } \\
\text { GDP by expenditure. }\end{array}$ & Aug 11-14, 2014 \\
\hline FAD & $\begin{array}{l}\text { Medium-term debt } \\
\text { management (MTDS) } \\
\text { strategy }\end{array}$ & $\begin{array}{l}\text { Build analytical capacity in the Debt } \\
\text { Management Unit, demonstrate the application } \\
\text { and use of the MTDS toolkit, and support the } \\
\text { authorities in developing a MTDS strategy. }\end{array}$ & Mar 3-13, 2014 \\
\hline FAD & Tax policy & Review tax incentives and real property taxation. & Feb 4-19, 2014 \\
\hline FAD & PFM & $\begin{array}{l}\text { Review the PFM technical assistance provided } \\
\text { under the SEMCAR program. }\end{array}$ & Apr 23-May 2, 2013 \\
\hline
\end{tabular}




\begin{tabular}{|c|c|c|c|}
\hline \multicolumn{4}{|c|}{ St. Vincent and the Grenadines: Fund Technical Assistance, 2012-18 (concluded) } \\
\hline Department & Areas & Main objectives & Mission dates \\
\hline STA & $\begin{array}{l}\text { National accounts } \\
\text { statistics }\end{array}$ & $\begin{array}{l}\text { Assist the authorities in revising the estimates of } \\
\text { GDP by expenditure components. }\end{array}$ & Dec 10-14, 2012 \\
\hline FAD & Budget execution & $\begin{array}{l}\text { Improve the budget execution and treasury } \\
\text { operations. }\end{array}$ & Jun 4-22, 2012 \\
\hline FAD & $\begin{array}{l}\text { Public expenditure and } \\
\text { financial accountability } \\
\text { (PEFA) }\end{array}$ & Initiate a PEFA assessment exercise. & Mar 19-28, 2012 \\
\hline STA & $\begin{array}{l}\text { National accounts } \\
\text { statistics }\end{array}$ & $\begin{array}{l}\text { Assist the authorities in revising the estimates of } \\
\text { GDP by expenditure. }\end{array}$ & Jan 16-19, 2012 \\
\hline
\end{tabular}

AML/CFT: The last formal AML/CFT assessment for St. Vincent and the Grenadines was undertaken by Financial Action Task Force (FATF) in 2012 under the $40+9$ FATF standards. After the May 2013 Follow-up Report, St. Vincent and the Grenadines was placed in the first stage of the enhanced follow-up process for not making enough progress to comply with FATF recommendations. In 2016, the Caribbean Financial Action Task Force (CFATF) Plenary decided to advance the country to the second stage of enhanced follow-up process. In 2017, the government amended three laws and published procedures on AML/CFT measures. The 2018 Follow-Up Report noted progress to the AML/CFT framework in respect to the Core and Key recommendations, enough for St. Vincent and the Grenadines to exit from the third round of follow-up process. The next formal AML/CFT assessment is planned to be conducted by CFATF in the third quarter of 2021. 


\section{RELATIONS WITH THE WORLD BANK GROUP}

(As of December 13, 2018)

St. Vincent and the Grenadines is a member of four World Bank Group (WBG) institutions: the International Development Association (IDA), the International Bank for Reconstruction and Development (IBRD), the Multilateral Investment Guarantee Agency (MIGA) and the International Center for Settlement of Investment Disputes (ICSID). In 1982, the country joined IDA and IBRD; in 1990 joined MIGA; and in 2003, ICSID. St. Vincent and the Grenadines is not a member of the International Finance Corporation.

The WBG relationship with St. Vincent are the Grenadines is determined by the ongoing Regional Partnership Strategy (RPS) for the Organization of Eastern Caribbean States (OECS), which encompasses St. Vincent and the Grenadines and five other WBG member countries from the OECS. The RPS, originally expected to cover the FY2015-FY2019 period, was revised in May 2018 through a Performance and Learning Review (PLR) that extended the closing date through FY2020 (June 30, 2020).

St. Vincent and the Grenadines receives both financial and analytical support from the WBG. The country is eligible for concessional financing on IDA credit terms through the Small States Exception. Its indicative allocation for the IDA18 cycle (July 1, 2017-June 30, 2020) is 48.1 million Special Drawing Rights (SDR), equivalent to US\$66.6 million (at the December 13, 2018 exchange rate).

\section{A. Projects}

St. Vincent and the Grenadines participates in seven active investment project financing (IPF) operations for a total of US $\$ 97.6$ million. Six of these IPF projects are regional, and one is countryspecific. The six regional projects are in: (i) disaster risk management; (ii) information and communications technology; (iii) energy; (iv) tourism; (v) agriculture; and, (vi) access to finance. The country-specific project covers the human development areas of social protection and education. Four of these projects were approved in the last one and a half years. The total amount disbursed to date is equivalent to roughly three-quarters of the total commitments, and disbursements and debt service with the WBG, by calendar year is presented in Table 1. The planned WBG's pipeline for the country under IDA18 comprises the following operations: (i) a US\$ 6 million credit for the OECS Regional Health Project (US\$4 million of which are leveraged from a regional IDA fund outside St. Vincent's national allocation); (ii) a port modernization project, for a total of US\$30 million; and a programmatic series of two Development Policy Credits (DPCs) for a total of about US\$33 million.

\section{B. Advisory Services and Analytics (ASA)}

The WBG provides a series of ASA to St. Vincent and the Grenadines, both in the context of regional and country-specific initiatives. There is currently only one country-specific ASA for SVG supporting the technical assistance for the National Risk Assessment (NRA) for Anti-Money Laundering and Combating Finance Terrorism (AML/CFT). The regional ASA are very diverse and encompass support 
in several areas and themes around the overarching "resilience building" approach (e.g. renewable energy, disaster risk management, public sector systems).

\begin{tabular}{|c|c|c|c|c|c|c|c|c|}
\hline \multicolumn{9}{|c|}{$\begin{array}{l}\text { Table 1. World Bank Group Projects, as of December 13, } 2018 \\
\qquad \text { (In millions of US dollars) }\end{array}$} \\
\hline \multicolumn{9}{|l|}{ Active projects } \\
\hline & & & & & & Principal & Available & Disbursed \\
\hline \multicolumn{6}{|c|}{ OECS Regional Agriculture Competitiveness Project ${ }^{2}$} & 4.3 & 4.0 & 0.3 \\
\hline \multicolumn{6}{|c|}{ OECS Regional Tourism Competitiveness ${ }^{2}$} & 5.0 & 4.9 & 0.1 \\
\hline \multicolumn{6}{|c|}{ OECS MSME Facility Guarantee Project ${ }^{2}$} & 2.0 & 2.0 & 0.0 \\
\hline \multicolumn{6}{|c|}{ Regional Disaster Vulnerability Reduction Project ${ }^{2}$} & 71.0 & 52.9 & 18.1 \\
\hline \multicolumn{6}{|c|}{ Caribbean Regional Communications Infrastructure Program ${ }^{2}$} & 6.0 & 2.6 & 3.4 \\
\hline \multicolumn{6}{|c|}{ Solar PV Demonstration and Scale-Up Project ${ }^{2}$} & 0.6 & 0.0 & 0.6 \\
\hline \multicolumn{6}{|c|}{ Human Development Service Delivery Project } & 10.7 & 10.3 & 0.4 \\
\hline \multicolumn{6}{|c|}{ Total $^{1}$} & 97.6 & 74.7 & 22.9 \\
\hline \multicolumn{9}{|c|}{ Disbursements and debt service } \\
\hline \multicolumn{2}{|c|}{2011} & 2012 & 2013 & 2014 & 2015 & 2016 & 2017 & $2018^{3}$ \\
\hline \multirow{4}{*}{$\begin{array}{l}\text { Total disbursements } \\
\text { Repayments } \\
\text { Net disbursements } \\
\text { Interest and fees }\end{array}$} & 3.1 & 1.6 & 5.0 & 3.4 & 1.6 & 1.8 & 0.9 & 1.2 \\
\hline & 1.0 & 1.3 & 1.3 & 1.3 & 1.4 & 1.4 & 1.4 & 1.4 \\
\hline & 2.0 & 0.3 & 3.7 & 2.1 & 0.2 & 0.5 & -0.5 & -0.2 \\
\hline & 0.4 & 0.4 & 0.4 & 0.4 & 0.3 & 0.3 & 0.3 & 0.3 \\
\hline \multicolumn{9}{|c|}{$\begin{array}{l}\text { 1/ Amounts may not add up to principal due to changes in the SDR/USD exchange rate. } \\
\text { 2/ Regional project; only includes specific amounts for St. Vincent and the Grenadines. } \\
\text { 3/ January to December 13, } 2018\end{array}$} \\
\hline
\end{tabular}




\section{RELATIONS WITH THE CARIBBEAN DEVELOPMENT BANK (CDB)}

(As of December 13, 2018)

The strategic objectives of the CDB's country strategy for St. Vincent and the Grenadines (2014-18), are to: (i) accelerate and sustain inclusive economic growth; (ii) promote human and social development; and, (iii) enhance environmental sustainability and disaster risk management. The related assistance program entails financing commitments of up to US\$86.7 million inclusive of US\$21 million from Special Funds Resources (SFR), and the remaining US\$65.7 million from the CBD's Ordinary Capital Resources to help the authorities implement selected components of its National Economic and Social Development Plan for 2013-2025.

Since 2018 to date, the CDB has approved US\$22.2 million in new loans and disbursed US\$7.0 million to St. Vincent and the Grenadines. Against the backdrop of increasing intensity and frequency of natural disasters and greater vulnerability, disaster risk management and community resilience building remained center-stage in CDB's strategic responses to the challenges facing St. Vincent. The country is exposed to high levels of risk to meteorological and geophysical hazards, which have significant negative impacts on economic and fiscal stability. These natural hazards are being exacerbated by the adverse impacts of climate variability and climate change, which place increased stress on water availability, coastal protection investments, food security, national infrastructure and livelihoods, especially of the poor and vulnerable groups. Following severe meteorological events in 2016 and 2017, additional project financing was approved during 2018 to support climate resilient and adaptation infrastructure investments, and reduce vulnerability to extreme rainfall, storm surges and other climate change impacts. Infrastructure works include coastal and river defense works, bridge and road upgrade and rehabilitation, as well as slope and embankment stabilization.

Grant funds were also approved through CDB's Community Disaster Risk Reduction Fund - a multidonor trust fund - to implement "Volcano-Ready Communities in St. Vincent and the Grenadines", a two-year project to prepare vulnerable communities to manage potential impacts of La Soufrière Volcano and related hazards. On successful completion, St. Vincent would be the first country in the Region to hold the "Volcano-Ready" designation. The project targets 12 towns and villages in the high-risk zones of La Soufrière. It specifically seeks to improve early warning and alert systems; train early response and risk assessment teams; develop a "Volcano-Ready" framework and toolkit for communities; and create public education and awareness materials to be shared with schools, businesses, and residents.

Cumulative loans approved since 1970 stands at US $\$ 233.9$ million of which US $\$ 172.5$ million is disbursed. The disbursed debt outstanding amounts to US $\$ 106.7$ million. Details of the active loan portfolio are highlighted in Table 2. 
Table 2. CDB Projects, as of December 13, 2018

(In millions of US dollars)

Active projects

Approved Undisbursed

Disaster Risk Reduction and Climate Change Adaptation

$25.7 \quad 25.5$

Rehab/ Reconstruction - Hurricane Tomas

$12.6 \quad 5.9$

South Leeward Highway Rehabilitation

$13.6 \quad 3.2$

Rehab/ Reconstruction - Dec 2013 Trough

$16.7 \quad 13.5$

Technical and Vocational Education and Training Development

$12.3 \quad 9.8$

Energy Efficiency Measures and Solar Voltaic Plant

Total

4.2

4.2

85.1

62.1

Disbursements and debt service

\begin{tabular}{|lcccccc|}
\hline & $\mathbf{2 0 1 3}$ & $\mathbf{2 0 1 4}$ & $\mathbf{2 0 1 5}$ & $\mathbf{2 0 1 6}$ & $\mathbf{2 0 1 7}$ & $\mathbf{2 0 1 8}^{\mathbf{1}}$ \\
\hline Net disbursement & 1.5 & -0.6 & -3.0 & -2.8 & -5.5 & -2.6 \\
Disbursement & 7.2 & 6.6 & 4.6 & 7.1 & 4.7 & 7.0 \\
Amortization & 5.7 & 6.0 & 7.6 & 9.9 & 10.2 & 9.6 \\
Interest and charges & 4.1 & 4.4 & 4.1 & 3.4 & 3.4 & 3.8 \\
\hline & & & & & & \\
$1 /$ January to December 13, 2018 & & & & & &
\end{tabular}




\section{STATISTICAL ISSUES}

(As of December 13, 2018)

\section{ST. VINCENT AND THE GRENADINES-STATISTICAL ISSUES}

\section{Assessment of Data Adequacy for Surveillance}

General: Data provision has some shortcomings but is broadly adequate for surveillance.

National Accounts: The Statistical Office (SO) has been disseminating annual GDP estimates by economic activity and expenditure at current and constant 2006 prices since 2011. The SO commenced releasing quarterly GDP estimates by economic activity at constant prices in July 2018. A CARTAC mission to be undertaken in January 2019 will assist with development of the quarterly GDP estimates at current prices and the framework for the 2018 Supply and Use Tables. A medium-term action plan to improve and expand the national accounts aggregates has been developed. It will be necessary to increase the staffing and other resources of the SO in order to implement the action plan. In addition, improvements are needed on data used to monitor labor markets.

Price Statistics: A current CPI index series (with January 2010 as the base) was introduced in June 2011 with assistance from CARTAC. The current index uses a Household Budget and Expenditure Survey (HBES) that took place in 2008. As part of the CARTAC's assistance with the current CPI index, it helped link the 2001 based to the 2010-based CPI series. The SO has not produced producer price index (PPI), and export and import price indices (XMPIs). The SO conducted a HBES in 2018 and the data will be used to reweight the CPI basket during 2019.

Government Finance Statistics: Due to delays in reporting capital expenditures by some ministries, monthly revenue and expenditure data for the central government are provided to the International Monetary Fund with some lag. Discrepancies exist between the fiscal and monetary accounts, between above and below the line for budget data, and between financing and debt data. The financial reports of public enterprises are not timely, with about a two-year lag. Fiscal data provided for surveillance are based on the Government Finance Statistics Manual (GFSM) 1986 framework, and it is desirable for the country to develop capacity and migrate to reporting based on the GFSM 2014 framework, which would support enhanced DSA as well as application of intersectoral BSA.

Monetary and Financial Statistics: Monthly monetary statistics are compiled and reported to the Fund by the ECCB, based on standardized report forms (SRF) for the central bank (SRF 1SR) and for other depository corporations (SRF 2SR), since July 2006. The main shortcomings of the monetary statistics relate to incomplete institutional coverage of other depository corporations. Specifically, mortgage companies, finance companies, building societies, and credit unions-all of which accept deposits-are not covered by the monetary statistics. Also, 
accrued interest is not incorporated in the value of the interest-bearing assets and liabilities, and valuation adjustments are included in other liabilities. To achieve better coverage, close coordination between the ECCB and the Financial Services Authority (which supervises financial corporations other than those licensed under the Banking Act) is crucial. The ECCB is currently working on implementing a new reporting system for commercial banks that is envisaged to address the recommendations made by the past TA mission. It is expected that the new reporting system would be implemented in the next few years.

Financial Sector Surveillance: The ECCB reports all core and 10 additional financial soundness indicators (FSIs) for deposit takers in St. Vincent.

External sector statistics: Since 2017, annual balance of payments and international investment position (IIP) data have been compiled and disseminated following the latest international standard methodology (BPM6). Education-related services provided to nonresident students by the offshore universities, which were omitted in the former methodology, are now included as travel services exports. CARTAC continues to assist the SO and the Tourism Authority in strengthening the visitor expenditure survey. The response rate to the business surveys is one of the lowest in the ECCU. As advised by CARTAC, the SO is approaching administrative sources to reduce data gaps. Actions for improvements are coordinated by the $\mathrm{SO}$ with the ECCB, which jointly compile the external sector statistics of St. Vincent and the Grenadines and the rest of the ECCU.

\section{Data Standards and Quality}

St. Vincent and the Grenadines has been participating in the General Data Dissemination System since September 2000 and currently participates in its successor initiative, the e-GDDS. The 2007 regional data ROSC provides an assessment on the ECCB's monetary statistics. No data ROSC is available for other sectors. 


\begin{tabular}{|c|c|c|c|c|c|}
\hline \multicolumn{6}{|c|}{$\begin{array}{l}\text { St. Vincent and the Grenadines: Table of Common Indicators Required for Surveillance } \\
\text { (As of December 13, 2018) }\end{array}$} \\
\hline & $\begin{array}{l}\text { Date of latest } \\
\text { observation }\end{array}$ & Date received & $\begin{array}{l}\text { Frequency of } \\
\text { data }^{3}\end{array}$ & $\begin{array}{l}\text { Frequency of } \\
\text { reporting }^{3}\end{array}$ & $\begin{array}{l}\text { Frequency of } \\
\text { publication }^{3}\end{array}$ \\
\hline Exchange rate & \multicolumn{5}{|c|}{ Fixed exchange rate regime } \\
\hline $\begin{array}{l}\text { International reserve assets and reserve liabilities } \\
\text { of the monetary authorities }\end{array}$ & September 2018 & November 2018 & M & M & M \\
\hline Reserve/base money & September 2018 & November 2018 & M & M & M \\
\hline Broad money & September 2018 & November 2018 & M & M & M \\
\hline Central bank balance sheet & September 2018 & November 2018 & M & M & M \\
\hline Consolidated balance sheet of the banking system & September 2018 & November 2018 & M & M & M \\
\hline Interest rates & September 2018 & November 2018 & M & M & M \\
\hline Consumer price index & November 2018 & December 2018 & $M$ & M & $M$ \\
\hline $\begin{array}{l}\text { Revenue, expenditure, balance and composition } \\
\text { of financing-central government }\end{array}$ & September 2018 & November 2018 & M & M & $\mathrm{Q}$ \\
\hline $\begin{array}{l}\text { Revenue, expenditure, balance and composition } \\
\text { of financing-general government }{ }^{1}\end{array}$ & September 2014 & November 2014 & M & 1 & I \\
\hline $\begin{array}{l}\text { Stock of central government and central } \\
\text { government-guaranteed debt }{ }^{2}\end{array}$ & September 2018 & November 2018 & I & I & A \\
\hline External current account balance & 2017 & September 2018 & A & A & A \\
\hline Exports and imports of goods and services & 2017 & September 2018 & A & A & A \\
\hline GDP & Q2 2018 & November 2018 & $\mathrm{Q}$ & $\mathrm{Q}$ & $\mathrm{Q}$ \\
\hline Gross external debt & 2017 & September 2018 & A & A & A \\
\hline International Investment Position & 2017 & September 2018 & A & A & A \\
\hline
\end{tabular}

${ }^{1}$ The general government consists of the central government (budgetary funds, extra budgetary funds, and social security funds) and state-owned enterprises. ${ }^{2}$ Including domestic and external composition and maturity.

${ }^{3}$ Daily (D), Weekly (W), Monthly (M), Quarterly (Q), Half-yearly (H), Annually (A), Irregular (I), 


\section{INTERNATIONAL MONETARY FUND}

January 24, 2019

\section{ST. VINCENT AND THE GRENADINES}

\section{STAFF REPORT FOR THE 2018 ARTICLE IV CONSULTATION- DEBT SUSTAINABILITY ANALYSIS}

\author{
Approved By \\ Patricia Alonso-Gamo, \\ Johannes Wiegand (IMF), \\ and Paloma Anos-Casero \\ (IDA).
}

Prepared by the staffs of the International Monetary Fund and the International Development Association.

\begin{tabular}{|l|c|}
\hline Risk of external debt distress (current policies): & High \\
\hline Overall risk of debt distress & High \\
\hline Granularity in the risk rating & Sustainable \\
\hline Application of judgement & No \\
\hline
\end{tabular}

The overall assessment is broadly unchanged from the 2017 Article IV Staff Report. After peaking at 83 percent of GDP in 2016, total public debt fell to 74 percent of GDP in 2017. Public and publicly guaranteed external debt fell from 57 percent in 2016 to 47 percent of GDP in 2017. This reflects improvements in the fiscal position in the last two years and two rounds of debt forgiveness with a bilateral creditor in 2017.

Nonetheless, the risk of external and public debt distress remains high. ${ }^{7}$ Public external debt is projected to decline over the medium-term, but its present value (PV) is projected to stay above the indicative threshold (40 percent of GDP) until 2020 under the baseline scenario (Figure 1). The PV of total public debt is projected to stay above the indicative threshold (55 percent of GDP) until 2030 (Figure 2).

The DSA results highlight key risks to debt dynamics stemming from weaker-than-expected growth and more severe natural disaster hazards due to climate change. The authorities could consider additional fiscal measures to guard against adverse events and to firmly put public debt on a downward path toward the Eastern Caribbean Currency Union's (ECCU) regional target of 60 percent of GDP.

\footnotetext{
${ }^{1}$ St. Vincent and the Grenadines' score in the Composite Indicator is 2.98 pointing that the country's debt carrying capacity is classified as medium. The classification determines the corresponding debt and debt service thresholds for the external public and publicly-guaranteed external debt and for total public debt.
} 


\section{BACKGROUND ON PUBLIC SECTOR DEBT}

1. There are no data gaps in public sector debt coverage (Text Table 1). Public sector debt includes central government debt and state-owned enterprises (SOEs) debt. ${ }^{2}$ As of end-2017, the outstanding stock of public debt was EC $\$ 1.6$ billion (74.2 percent of GDP), of which central government debt was EC $\$ 1.3$ billion (62.4 percent of GDP), and SOEs debt was EC $\$ 0.2$ billion (11.8 percent of GDP). ${ }^{3}$

\begin{tabular}{|ll|}
\hline \multicolumn{1}{|c|}{ Text Table1. Coverage of Public Sector Debt } \\
\hline \\
Subsectors of the public sector & Central government \\
2 & State and local government \\
3 & Other elements in the general government \\
4 & O/w: Social security fund \\
5 & O/w: Extra budgetary funds (EBFs) \\
6 & Guarantees (to other entities in the public and private sector, including to SOEs) \\
7 & Central bank (borrowed on behalf of the government) \\
8 & Non-guaranteed SOE debt \\
\hline
\end{tabular}

2. The stock of public debt has declined as a percent of GDP, reflecting progress with fiscal consolidation and debt forgiveness. Public debt fell from 82.8 percent of GDP in 2016 to 74.2 percent of GDP in 2017 reflecting a primary surplus position and two rounds of debt forgiveness with Venezuela (US\$85 million in June 2017 and US\$81 million in September 2017 equal to $73 / 4$ percent of GDP).

\section{The composition of public debt is} dominated by external debt (Text Figure 1). As of end 2017, the stock of external debt accounted for around 64 percent of total public debt, while domestic debt accounted for 36 percent of total public debt, in the form of treasury bills and government bonds (53 percent of total domestic debt); loans in local currency (38 percent); and accounts payable (about 9 percent). ${ }^{4}$ Most of the government securities are held by the buy-and-

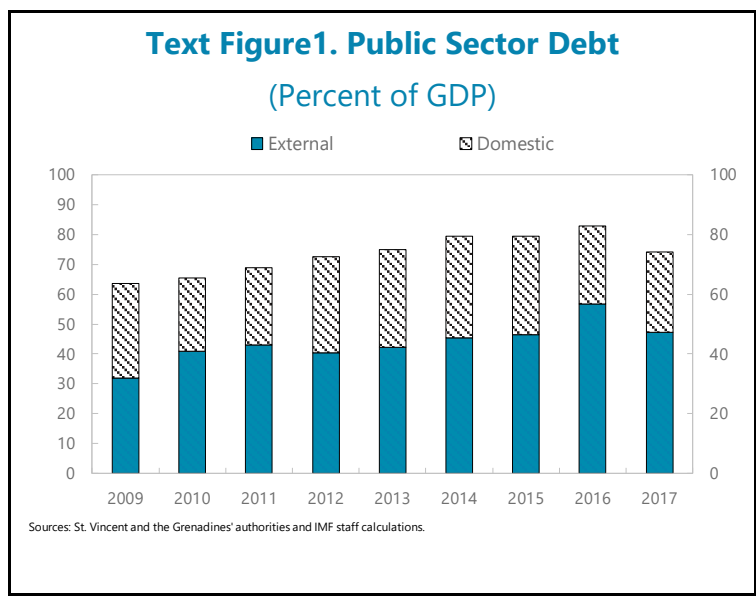
hold national pension system. Additionally, the government has in place a sinking fund (about 1.5 percent of GDP) for the repayment of government securities and to reduce potential rollover risks.

\footnotetext{
${ }^{2}$ Note that there are no local governments. In addition, all of SOEs' external debt is guaranteed by the central government.

${ }^{3}$ There is a EC\$300 million limit on SOEs' total debt.

${ }^{4}$ Debt classification is based on a residency basis, treating local currency-denominated debt issued in the local debt market and held by non-residents as external debt.
} 


\section{External public debt fell from $\mathbf{5 6 . 7}$ percent of GDP in 2016 to $\mathbf{4 7 . 4}$ percent of GDP in}

2017. The decline in external debt was due to improvements in the fiscal position over the last two years and two rounds of debt forgiveness with Venezuela. Most public external debt is with multilateral and bilateral donors (47.6 percent and 38.6 percent of total, respectively) on concessional terms. The remaining 13 percent is on commercial terms (Text Figure 2 and Text Table 2).

\begin{tabular}{|lr|}
\hline \multicolumn{2}{|c|}{ Text Table 2. Public Sector External Debt, 2017} \\
(Percent of total and percent of GDP) \\
\hline Total & $\mathbf{1 0 0 . 0}$ \\
Multilateral Institutions & $\mathbf{4 7 . 6}$ \\
World Bank & 9.0 \\
Caribbean Development Bank & 33.8 \\
IMF & 2.9 \\
Others & 1.9 \\
Bilateral Creditors & $\mathbf{3 8 . 6}$ \\
USAID & 0.7 \\
France & 0.4 \\
Venezuela & 24.9 \\
Others & 12.6 \\
Private Creditors & $\mathbf{1 3 . 8}$ \\
\hline Source: Ministry of Finance, St. Vincent and the Grenadines. \\
1 Includes commercial banks, insurance companies, pension funds, \\
among others.
\end{tabular}

Text Figure 2. Public Publicly Guaranteed External Debt

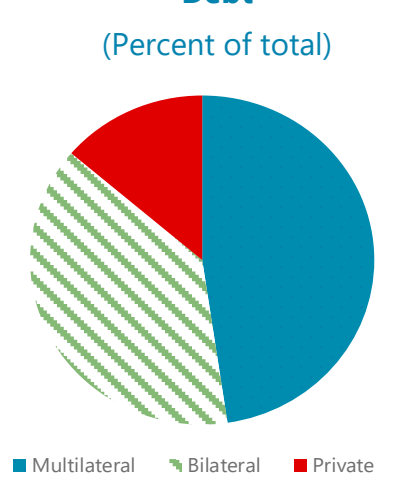

Sources: St. Vincent and the Grenadines' authorities and IMF staff calculations.

\section{CHANGES IN THE MACROECONOMIC FORECAST RELATIVE TO PREVIOUS DSA}

\section{The macroeconomic assumptions underlying the baseline scenario are consistent with} the macroeconomic framework discussed in the Staff Report. Main revisions since the 2017 Article IV consultation are as following (Text Table 3).

- The near-term growth outlook is largely unchanged, with real GDP growth (based on market prices) expected to rebound from 0.9 percent in 2017 to 2.0 percent in 2018, supported by higher stay-over tourism arrivals and tourism-related activities. However, medium- to long-term growth projections have been revised down, from the 2.8-3 percent growth assumed in the 2017 Article IV Staff Report to around 2.3 percent, reflecting more moderate and realistic growth rates of public capital spending and net FDI inflows

- Growth of the GDP deflator is estimated at 3.2 percent in 2018 reflecting increases in oil and food prices (up from 2.1 percent in the 2017 Article IV Staff Report) but is projected to moderate to 2 percent in $2020-30$ broadly in line with the U.S. inflation. ${ }^{5}$

\footnotetext{
${ }^{5}$ St. Vincent and the Grenadines is a member of the Eastern Caribbean Currency Union, and the exchange rate peg against the U.S. dollar provides an anchor for inflation.
} 
- The current account deficit is projected to narrow over the medium-term from 16 percent of GDP in 2018 to about 12 percent of GDP in 2022, similar to the path assumed in the 2017 Staff Report. This reflects improvements in the trade balance driven by rising exports of goods and services associated with the increase in tourism activity and non-traditional exports and lower dependence on imported fuels once the new geothermal project comes on stream.

- $\quad F D I$ is projected to remain steady over the medium-term at around 12.5 percent of GDP reflecting the construction and expansion of hotels. FDI will remain the main source of financing of the current account deficit.

- The average primary balance for the public sector is assumed at a surplus of 1.1 percent of GDP for the projection horizon. This is slightly higher than the DSA scenario in the 2017 report, reflecting the government's positive track record in containing recurrent spending (including the wage bill and transfers and subsidies in recent years).

- Long-term external and domestic financing mix. About one third of the deficit is assumed to be financed by external sources and the remaining two thirds by domestic sources. External loan disbursements include those from existing loan contracts (US $\$ 170$ million) and new loans (US\$100 million). Most of the new financing is expected to come from multilateral and bilateral donors, including budget support and projects (e.g., geothermal power plant, new port and ferry, coastal protection, and agribusiness). These reflect the increase in IDA resources, which will contribute to raise the grant element of new disbursements to an average of 38.5 percent over the projection period compared to 22.4 percent in 2018.

Text Table 3. St. Vincent and the Grenadines: Selected Macroeconomic Indicators Assumptions

\begin{tabular}{|c|c|c|c|c|c|c|}
\hline & 2017 & 2018 & 2019 & 2020 & 2021 & 2022 \\
\hline \multicolumn{7}{|l|}{2017 DSA } \\
\hline Nominal GDP (EC\$, millions) & 2,164 & 2,255 & 2,353 & 2,454 & 2,566 & 2,679 \\
\hline Real GDP growth, (percent change), factor cost & 1.0 & 2.1 & 2.5 & 2.8 & 3.0 & 3.0 \\
\hline Real GDP growth, (percent change), market price & 1.1 & 2.0 & 2.4 & 2.6 & 2.8 & 2.8 \\
\hline Inflation (GDP deflator, percent change) & 3.1 & 2.1 & 1.8 & 1.5 & 1.5 & 1.3 \\
\hline Current account balance (percent of GDP) & -14.3 & -13.6 & -13.3 & -12.5 & -11.6 & -10.9 \\
\hline Central government primary balance (percent of GDP) & 0.2 & 0.5 & 0.6 & 0.7 & 0.7 & 0.7 \\
\hline Central government fiscal balance (percent of GDP) & -2.4 & -2.0 & -1.9 & -1.8 & -1.8 & -1.7 \\
\hline Public sector, primary balance (percent of GDP) & 0.3 & 0.4 & 0.4 & 0.5 & 0.5 & 0.5 \\
\hline Public sector, fiscal balance (percent of GDP) & -1.7 & -2.6 & -2.6 & -2.4 & -2.4 & -2.3 \\
\hline Total public debt (percent of GDP) & 77.5 & 78.5 & 78.6 & 78.4 & 77.9 & 77.7 \\
\hline \multicolumn{7}{|l|}{ Current DSA } \\
\hline Nominal GDP (EC\$, millions) & 2,120 & 2,231 & 2,334 & 2,438 & 2,544 & 2,655 \\
\hline Real GDP growth, (percent change), factor cost & 0.7 & 2.0 & 2.3 & 2.4 & 2.3 & 2.3 \\
\hline Real GDP growth, (percent change), market price & 0.9 & 2.0 & 2.3 & 2.4 & 2.3 & 2.3 \\
\hline Inflation (GDP deflator, percent change) & 2.2 & 3.2 & 2.3 & 2.0 & 2.0 & 2.0 \\
\hline Current account balance (percent of GDP) & -17.2 & -15.9 & -15.0 & -14.0 & -13.2 & -12.4 \\
\hline Central government primary balance (percent of GDP) & 1.9 & 0.6 & 0.8 & 1.0 & 1.0 & 1.1 \\
\hline Central government fiscal balance (percent of GDP) & -0.5 & -2.0 & -1.7 & -1.5 & -1.4 & -1.3 \\
\hline Public sector, primary balance (percent of GDP) & 1.9 & 0.6 & 0.8 & 1.0 & 1.0 & 1.1 \\
\hline Public sector, fiscal balance (percent of GDP) & -0.5 & -2.0 & -1.9 & -1.7 & -1.7 & -1.6 \\
\hline Total public debt (percent of GDP) & 74.2 & 73.0 & 71.3 & 69.6 & 68.0 & 66.6 \\
\hline
\end{tabular}




\section{REALISM OF THE MACROFRAMEWORK}

6. Debt dynamics (Figure 3). Over the next five years, the expected increase in direct flights would boost tourism receipts (contributing to smaller current account deficits) and private investment (contributing to steady net FDI inflows), which would help to contain an increase in the external debt-to-GDP ratio. The projected improvement in the primary balance and higher growth would contribute to reduce the public debt-to-GDP ratio. Public debt is projected to fall faster than assumed in the 2017 report, mainly because the primary surplus is higher than previously assumed.

7. Staff considers the baseline scenario as realistic (Figure 4). The projected fiscal adjustment could exert some drag on growth in 2019. However, the expected increase in tourist arrivals would boost tourism-related activities such as hotels, restaurants, and retail trade, supporting private-sector led growth. The fiscal adjustment over the medium-term is also assumed to be moderate. The primary balance is projected to improve from 0.6 percent of GDP in 2018 to 0.8 percent of GDP in 2019, and gradually to 1.1 percent of GDP by 2022 by restraining recurrent spending. The contribution of public capital to real GDP growth is projected to be slightly negative mainly because the growth rate of public capital spending in 2018 is negative. Excluding 2018, the contribution to real GDP growth is neutral.

\section{COUNTRY CLASSIFICATION}

8. St. Vincent's debt-carrying capacity is medium (Text Table 4). St. Vincent's Composite Indicator $(\mathrm{Cl})$ index (which determines the indicative thresholds to assess a country's debt sustainability) is calculated as 2.98 , corresponding to a "medium" rating. ${ }^{6}$ St. Vincent's debt carrying capacity is unchanged compared to the rating under the previous Country Policy and Institutional Assessment (CPIA) methodology. ${ }^{7}$ The corresponding scores for the $\mathrm{Cl}$ index determine the relevant thresholds for St. Vincent and the Grenadines for both external and total public debt (Text Table 5).

\footnotetext{
${ }^{6}$ The $\mathrm{Cl}$ index captures the impact of the weighted average of the World Bank's CPIA score, the country's real economic growth, remittances, international reserves, and world growth. The $\mathrm{Cl}$ calculation is based on 10-year averages of the variables including 5 years of historical data and 5 years of projections. The index was calculated using the October 2018 WEO data and the 2017 CPIA.

${ }^{7}$ Countries are rated based on a set of 16 backward-looking criteria grouped into four areas including economic management, structural policies, policies on social inclusion and equity, and public-sector management and institutions.
} 


\begin{tabular}{|c|c|c|c|c|}
\hline \multicolumn{5}{|c|}{ Text Table 4: Debt-Carrying Capacity Under the Composite Indicator Index } \\
\hline Components & Coefficients (A) & $\begin{array}{l}\text { 10-year average } \\
\text { values (B) }\end{array}$ & $\begin{array}{c}\text { CI Score components } \\
\left(A^{*} B\right)=(C)\end{array}$ & $\begin{array}{l}\text { Contribution of } \\
\text { components }\end{array}$ \\
\hline $\begin{array}{c}\text { CPIA } \\
\text { Real growth rate }\end{array}$ & 0.385 & 3.600 & 1.38 & $46 \%$ \\
\hline (in percent) & 2.719 & 1.669 & 0.05 & $2 \%$ \\
\hline 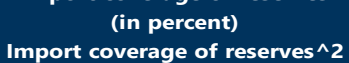 & 4.052 & 39.316 & 1.59 & $53 \%$ \\
\hline $\begin{array}{l}\text { (in percent) } \\
\text { Remittances }\end{array}$ & -3.990 & 15.457 & -0.62 & $-21 \%$ \\
\hline $\begin{array}{l}\text { (in percent) } \\
\text { World economic growth }\end{array}$ & 2.022 & 4.375 & 0.09 & $3 \%$ \\
\hline (in percent) & 13.520 & 3.579 & 0.48 & $16 \%$ \\
\hline CI Score & & & 2.98 & $100 \%$ \\
\hline Cl rating & & & Medium & \\
\hline
\end{tabular}

\begin{tabular}{|c|c|c|c|}
\hline \multicolumn{4}{|c|}{ Text Table 5: Composite Indicator Index: Thresholds } \\
\hline \multicolumn{4}{|c|}{ Text Table 5. Composite Indicator Index: Thresholds } \\
\hline External debt & Weak & Medium & Strong \\
\hline PV of external in percent of: & & & \\
\hline Exports & 140 & 180 & 240 \\
\hline GDP & 30 & 40 & 55 \\
\hline Debt service in percent of: & & & \\
\hline Exports & 10 & 15 & 21 \\
\hline Revenue & 14 & 18 & 23 \\
\hline $\begin{array}{l}\text { Total debt: PV of total public debt } \\
\text { in percent of GDP }\end{array}$ & 35 & 55 & 70 \\
\hline
\end{tabular}

\section{The combined contingent liability stress test is aligned to St. Vincent's specific risks}

(Text Table 6). The stress test includes the potential impact from existing Public-private partnerships (PPPs) and risks pertaining to financial markets. SOEs' debt is excluded from the stress test, as SOEs' debt is already included in total public debt. ${ }^{8}$

\begin{tabular}{|c|c|c|c|}
\hline \multicolumn{4}{|c|}{ Text Table 6: Combined Contingent Liability Shock } \\
\hline \multirow[t]{3}{*}{1 The country's coverage of public debt } & \multicolumn{3}{|c|}{ The central government, government-guaranteed debt } \\
\hline & \multicolumn{3}{|c|}{ Used for the } \\
\hline & Default & analysis & Reasons for deviations from the default settings \\
\hline 2 Other elements of the general government not captured in 1. & 0 percent of GDP & 0.0 & \\
\hline 3 SoE's debt (guaranteed and not guaranteed by the government) $1 /$ & 2 percent of GDP & 0.0 & \\
\hline 4 PPP & 35 percent of PPP stock & 13.7 & \\
\hline 5 Financial market (the default value of 5 percent of GDP is the minimum value) & 5 percent of GDP & 5.0 & \\
\hline Total $(2+3+4+5)$ (in percent of GDP) & & 18.7 & \\
\hline \multicolumn{4}{|c|}{$\begin{array}{l}\text { 1/ The default shock of } 2 \% \text { of GDP will be triggered for countries whose government-guaranteed debt is not fully captured under the country's public debt definition (1.). If it is already included in } \\
\text { the government debt (1.) and risks associated with SoE's debt not guaranteed by the government is assessed to be negligible, a country team may reduce this to } 0 \% \text {. }\end{array}$} \\
\hline \multicolumn{4}{|c|}{ There are no local governments in St. Vincent and the Grenadines. 100 percent of current SOEs' external debt is guaranteed by the central government. } \\
\hline
\end{tabular}

\footnotetext{
8 Potential contingent liabilities from the pension system are not included. Parametric reforms introduced in 2014 improved the sustainability of the National Insurance System (NIS), but only temporary, as its reserves are projected to be depleted by around 2033. Currently, the government is assessing options to further strengthen NIS's financial position and to reduce the burden from the public service pension system.
} 


\section{DEBT SUSTAINABILITY ANALYSIS}

\section{A. Baseline Scenario}

\section{Baseline Natural Disaster Assumptions}

10. The impact of natural disasters is estimated based on St. Vincent and the Grenadines' historical experience (Text table 7). The average of total natural disaster damage is estimated at 1.5 percent of GDP for the period 1980-2017, at 2 percent for the last 15 years, and 3.9 percent for the last 5 years. Staff assumes that under the baseline scenario, natural disasters would occur at the magnitude and frequency of the past 15 years, and about $70-75$ percent of total damage would be borne by the public sector (i.e., annual fiscal costs of 1.4 percent of GDP a year). The baseline also assumes that 0.7 percent of GDP of the fiscal costs could be covered by the contingency fund and the remaining 0.7 percent of GDP by expenditure reserves included in the annual budget envelope.

\begin{tabular}{|c|c|c|c|c|c|}
\hline \multirow[t]{2}{*}{ Year } & \multirow[t]{2}{*}{ Type } & \multirow{2}{*}{$\begin{array}{c}\text { Total damage } \\
\text { (\% GDP) }\end{array}$} & \multirow{2}{*}{$\begin{array}{l}\text { Est. fiscal costs } \\
\quad(\% \mathrm{GDP})\end{array}$} & \multicolumn{2}{|c|}{ People affected } \\
\hline & & & & Number & llation \\
\hline 1980 & Hurricane Allen & 19.8 & & 20,500 & 20.9 \\
\hline 1987 & Floods & 2.8 & & 1,000 & 1.0 \\
\hline 1987 & Hurricane Emily & 3.0 & & 208 & 0.2 \\
\hline 1999 & Hurricane Lenny & 0.5 & & 100 & 0.1 \\
\hline 2002 & Hurricane Lili & 2.4 & & NA & NA \\
\hline 2004 & Hurricane Ivan & 1.0 & & 1,004 & 0.9 \\
\hline 2005 & Hurricane Emily & 1.5 & & 530 & 0.5 \\
\hline 2010 & Hurricane Tomas & 3.7 & & 6,100 & 5.6 \\
\hline 2011 & Floods & 3.8 & & 275 & 0.3 \\
\hline 2013 & Floods & 15.0 & & 17,422 & 15.8 \\
\hline 2016 & Floods & 4.7 & & 25,000 & 22.7 \\
\hline \multicolumn{6}{|c|}{ Annual average } \\
\hline \multicolumn{2}{|c|}{ Full sample (1980-2017) } & 1.5 & 1.1 & & \\
\hline \multicolumn{2}{|c|}{ Last 20 years (1998-2017) } & 1.6 & 1.2 & & \\
\hline \multicolumn{2}{|c|}{ Last 15 years (2003-2017) } & 2.0 & 1.4 & & \\
\hline \multicolumn{2}{|c|}{ Last 10 years (2008-2017) } & 2.7 & 2.0 & & \\
\hline \multicolumn{2}{|c|}{ Last 5 years (2013-2017) } & 3.9 & 2.9 & & \\
\hline
\end{tabular}

\section{External Debt Sustainability Analysis}

11. St. Vincent and the Grenadines' risk of external debt distress is high. Under the baseline scenario, the PV of debt-to-GDP ratio would fall below the indicative threshold of 40 percent of GDP in 2021 (Figure 1 and Table 1). However, it breaches the threshold for an extended period under stress test scenarios, including due to shocks to growth, exports, and a hypothetical one-time 30 percent depreciation (Tables 3 and 4). The shock that generates the largest impact on the PV of debt-to-GDP ratio is the shock to exports. In this case, it breaches the threshold for an extended period until 2028, longer than in the baseline scenario.

\section{Furthermore, the PV of debt-to-exports ratio and the debt service-to-exports} thresholds are breached under standardized stress test scenarios. A shock to exports pushes the debt service-to-exports ratio above the 15 percent threshold for five years (2019-2023). The shock to exports temporarily pushes the ratio for the PV of debt-to-exports ratio above its indicative threshold. 
13. The other indicator of external public debt sustainability remains below its indicative threshold. The debt service-to-revenue ratio remains at comfortable levels in the baseline and shock scenarios. (Figure 1).

\section{Public Debt Sustainability Analysis}

14. The ECCU debt target of 60 percent of GDP can be achieved by around 2030, but the overall risk of debt distress is high (Figure 2 and Table 2). The PV of public debt is estimated at 74 percent of GDP in 2018, well above the indicative threshold of 55 percent of GDP. Under the "most extreme stress scenario," which assumes real GDP growth equal to its historical average (10 years) minus one standard deviation for 2019 and 2020, public debt becomes unsustainable, and its PV would reach 100 percent of GDP by 2024. Under other alternative scenarios including a shock to exports, a hypothetical 30 percent depreciation, or the tailored test of "one-time natural disaster" (see below), the PV of public debt (in percent of GDP) would stay constantly above the 55 percent threshold.

\section{B. Alternative Scenarios}

15. Two alternative scenarios are considered consistent with St. Vincent and the Grenadines' characteristics and recent experience. These scenarios reflect downside risks to the medium-term growth outlook and natural disaster risks.

\section{Low Growth Scenario}

16. The growth recovery would not be sustained, if global growth slows, dampening tourist arrivals and tourism-related activities. Medium-term output growth is assumed to stay at around 1.4 percent (the average growth rate for 2013-2017) (Text Figure 3 and Text Table 8). Despite lower growth rates, it is assumed that the authorities remain committed to meeting the ECCU's debt target and thus would maintain the primary balance position at a surplus of around 1 percent of GDP on average (unchanged from the baseline scenario).

17. Due to lower GDP growth, the pace of debt reduction would be much slower. St. Vincent and the Grenadines would not be able to meet the ECCU's 60 percent debt target by 2030 .

\section{Natural Disasters Scenarios}

18. Two natural disaster scenarios are conducted which reflect the country's exposure to natural disasters: (i) a one-time very severe natural disaster occurring in 2019; and (ii) recurrent severe natural disasters (less severe but more frequent events than the one-time natural disaster scenario, but more severe than the baseline scenario).

- One-time natural disaster in 2019. The fiscal costs due to the damages from this severe disaster are assumed to be 10 percent of GDP, in addition to the 1.4 percent of GDP assumed in 
the baseline scenario. The total fiscal cost of 11.4 percent of GDP is similar to the 2013 natural disaster experience - total damages and losses were estimated at 15 percent of GDP, of which about 12 percent of GDP were borne by the government. Under this scenario, real GDP growth is assumed to fall to 0.5 percent in 2019 compared to 2.3 percent in the baseline scenario, but it rebounds in 2020 reflecting the reconstruction efforts. The government is assumed to finance the fiscal costs through new debt. The results show that the PV of public debt would jump from 74 percent in 2018 to 86 percent of GDP in 2019 and remain high over the long-term (Top chart, Figure 2).

- Recurrent more severe natural disasters (less severe than the one-time natural disasters) (Text Figure 3 and Text Table 8). This scenario assumes that natural disasters hit the country at the frequency and magnitude of the last 10 years (i.e., annual total damages and annual fiscal costs of 2.7 percent and 2 percent of GDP, respectively). This implies additional annual fiscal costs of 0.6 percent of GDP compared to the baseline scenario. Under this scenario, real GDP growth slows down to 1.4 percent over the projection period reflecting the recurrent nature of the disasters. It is also assumed that the additional fiscal costs are financed through debt. Under this scenario, public debt would hover around 72-74 percent of GDP.

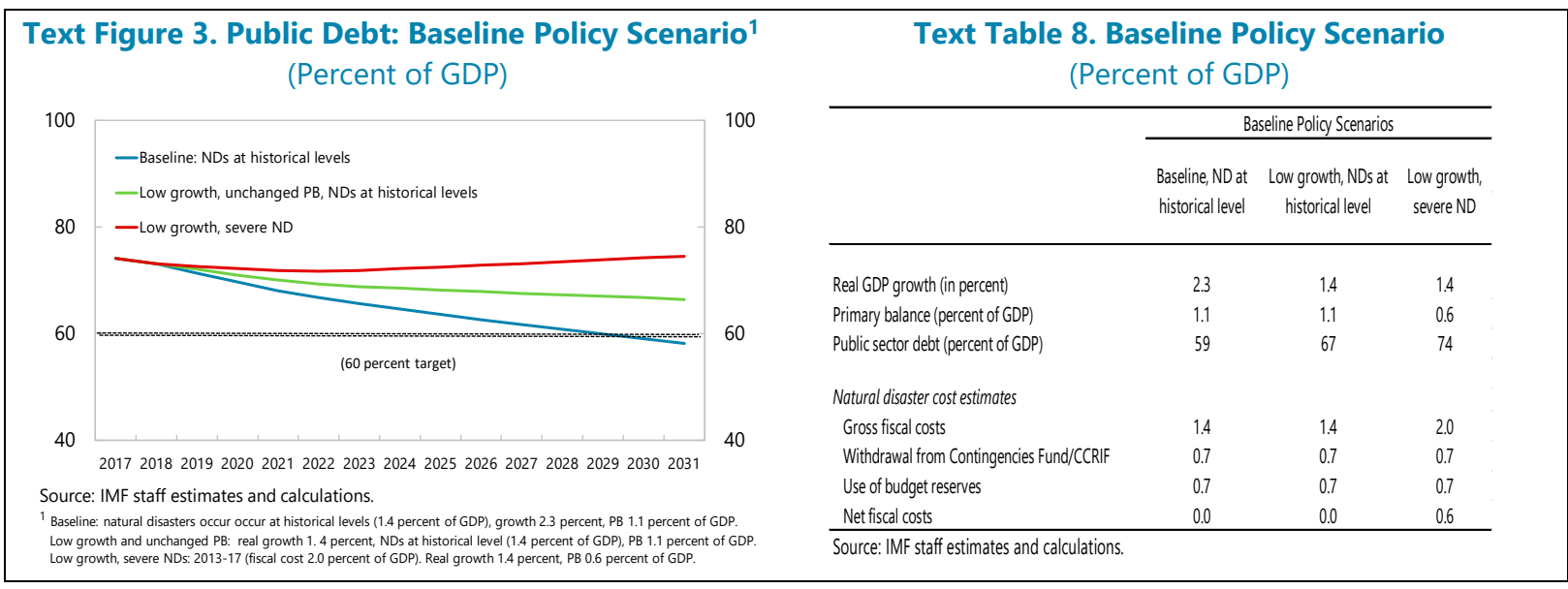

\section{Active Policy Scenario}

\section{The authorities could aim at a higher primary balance target to ensure debt} sustainability even under the above adverse scenarios (Text Figure 4 and Text Table 9). ${ }^{9}$ If the authorities raise the primary balance to a surplus of 1.6 percent of GDP by 2020, public debt would fall below 60 percent of GDP by around 2030 even if GDP growth would remain persistently low at 1.4 percent. ${ }^{10}$ The higher level of the primary balance would also ensure that public debt would

\footnotetext{
${ }^{9}$ There is a broad set of tax and expenditure measures that can be explored. These include reducing tax exemptions and streamlining zero-rated goods, containing the growth of the wage bill, and reforming the pension system (see Paragraph 20 of the Staff Report).

${ }^{10}$ Fiscal multipliers are likely small because St. Vincent and the Grenadines is a small and open economy, with imports accounting for nearly 40 percent of GDP. In addition, many proposed fiscal measures (see Staff Report
}

(continued) 
stabilize at the current level even if the economy is hit by more severe recurrent natural disasters and growth is persistently low.

\begin{tabular}{|c|c|c|c|c|c|c|}
\hline \multicolumn{3}{|c|}{$\begin{array}{l}\text { Text Figure 4. Public Debt: Active Policy Scenario' } \\
\text { (Percent of GDP) }\end{array}$} & \multicolumn{4}{|c|}{$\begin{array}{l}\text { Text Table 9. Active Policy Scenario } \\
\text { (Percent of GDP) }\end{array}$} \\
\hline \multirow{2}{*}{$\begin{array}{l}90 \\
80\end{array}$} & & \multirow{3}{*}{$\begin{array}{l}90 \\
80 \\
70\end{array}$} & & & \multicolumn{2}{|c|}{ Active Policy Scenarios } \\
\hline & & & & $\begin{array}{c}\& N D \text { at } \\
\text { historical level }\end{array}$ & $\begin{array}{l}\text { Low growth, NDs at } \\
\text { historical level }\end{array}$ & $\begin{array}{l}\text { Low growth, } \\
\text { severe ND }\end{array}$ \\
\hline 70 & & & Real GDP growth (in percent) & 2.3 & 1.4 & 1.4 \\
\hline 60 & - -Active, low growth, severe ND & 60 & $\begin{array}{l}\text { Primary balance (percent of GDP) } \\
\text { Public sector debt (percent of GDP) }\end{array}$ & $\begin{array}{l}1.1 \\
59\end{array}$ & $\begin{array}{l}1.6 \\
60\end{array}$ & $\begin{array}{l}0.9 \\
70\end{array}$ \\
\hline 50 & $\begin{array}{l}\text { - Active: } 1.6 \text { percent of GDP PB target, NDs at historical level, } \\
\text { - growth } 2.3 \text {, Low growth, active } 1.6 \text { percent of GDP PB target, severe ND }\end{array}$ & 50 & Natural disaster cost estimates & & & \\
\hline \multirow{2}{*}{40} & 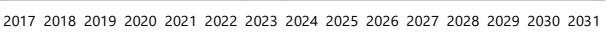 & \multirow{2}{*}{40} & Gross fiscal costs & 1.4 & 1.4 & 2.0 \\
\hline & & & Withdrawal from Contingencies Fund/CCRIF & 0.7 & 0.7 & 0.7 \\
\hline \multirow{3}{*}{\multicolumn{3}{|c|}{ 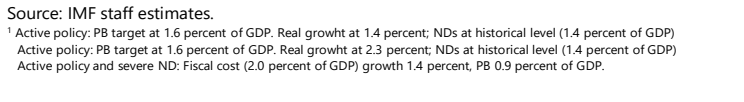 }} & Use of budget reserves & 0.7 & 0.7 & 0.7 \\
\hline & & & Net fiscal costs & 0.0 & 0.0 & 0.6 \\
\hline & & & Source: IMF staff estimates and calculations & & & \\
\hline
\end{tabular}

\section{RISK RATING AND VULNERABILITIES}

20. The risk of external and public debt distress is "high," unchanged from the assessment in the 2017 Article IV DSA. While the public and publicly guaranteed external debt and total public debt are projected to decline over the medium-term on the back of the improved fiscal position, the risk of external and public debt distress is expected to remain high.

\section{The stress tests and alternative scenarios tailored to St. Vincent and the Grenadines' idiosyncratic characteristics and recent growth experience highlight the benefits of taking} more active fiscal policies. The low growth and natural disasters scenarios reflect various downside risks to the baseline scenario. The results underscore the merits of building fiscal buffers more actively, in case growth falters or the country suffers more severe natural disasters, to ensure public debt sustainability. The low growth scenario also underlines the need to address the country's binding constraints to growth, including competitiveness and connectivity issues to be able to sustain growth at around 2.3 percent over the medium-to-long-term.

\section{AUTHORITIES' VIEWS}

\section{The authorities agreed with the debt sustainability assessment under the new}

framework and welcomed the tailored stress test on natural disaster. They were encouraged by their prudent fiscal policies over the last two years, which helped lower the debt-to-GDP ratio to 74 percent in 2017 for the first time since 2013. The authorities, however, recognized the risks that low growth and natural disasters pose to debt dynamics but reiterated their commitment to put

Paragraph 20) would not most likely affect households with liquidity constraints (e.g., pension reform or containing wage bill growth). Furthermore, fiscal consolidation efforts would improve investors' confidence and private sector activities. Accordingly, these active policy scenarios do not take account of adverse multiplier effects on growth. 
debt on a sustainable downward path to reach the ECCU's debt target of 60 percent of GDP by 2030 by implementing fiscal consolidation measures. They agreed that additional fiscal reforms would be needed to create fiscal space to support their capital spending program and, especially if the country suffers more severe natural disasters, to ensure public debt sustainability. 
Figure 1. St. Vincent $\&$ the Grenadines: Indicators of Public and Publicly Guaranteed External Debt under Alternatives Scenarios, 2018-2028
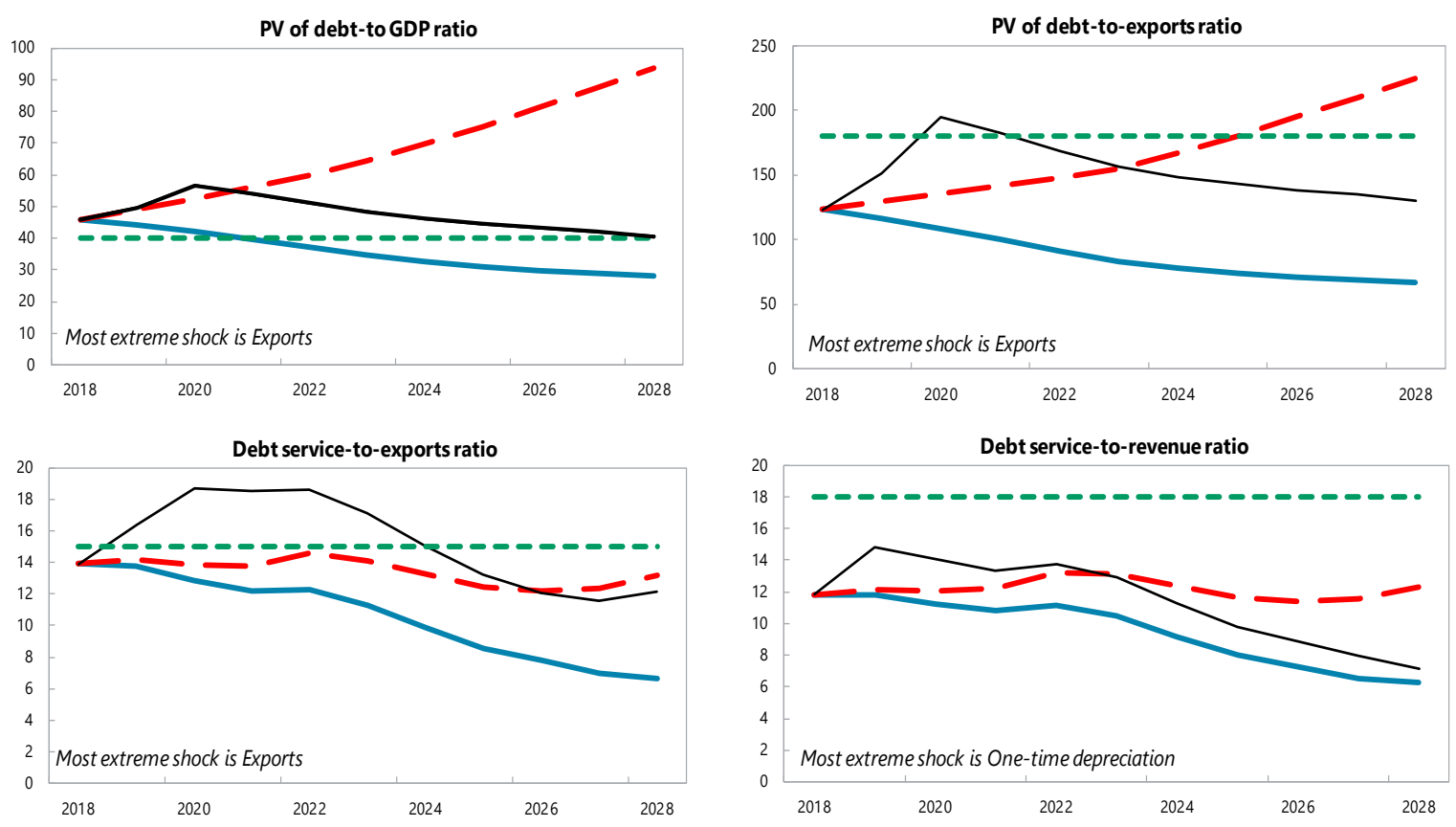

Baseline

\begin{tabular}{|c|c|c|}
\hline \multicolumn{3}{|c|}{ Customization of Default Settings } \\
\hline & Size & Interactions \\
\hline \multicolumn{3}{|l|}{ Tailored Tests } \\
\hline Combined CLs & Yes & \\
\hline Natural Disasters & Yes & Yes \\
\hline Commodity Prices $^{2 /}$ & n.a. & n.a. \\
\hline Market Financing & n.a. & n.a. \\
\hline
\end{tabular}

Note: "Yes" indicates any change to the size or interactions of the default settings for the stress tests. "n.a." indicates that the stress test does not apply.

\begin{tabular}{|c|c|c|}
\hline \multicolumn{3}{|c|}{ Borrowing Assumptions for Stress Tests* } \\
\hline & Default & User defined \\
\hline \multicolumn{3}{|l|}{ Shares of marginal debt } \\
\hline External PPG MLT debt & $100 \%$ & \\
\hline \multicolumn{3}{|l|}{ Terms of marginal debt } \\
\hline Avg. nominal interest rate on new borrowing in USD & $2.1 \%$ & $2.1 \%$ \\
\hline USD Discount rate & $5.0 \%$ & $5.0 \%$ \\
\hline Avg. maturity (incl. grace period) & 31 & 32 \\
\hline Avg. grace period & 7 & 7 \\
\hline
\end{tabular}

* Note: All the additional financing needs generated by the shocks under the stress tests are assumed to be covered by PPG external MLT debt in the external DSA. Default terms of marginal debt are based on baseline 10-year projections.

Sources: Country authorities; and staff estimates and projections.

1/ The most extreme stress test is the test that yields the highest ratio in or before 2028. Stress tests with one-off breaches are also presented (if any), while these one-off breaches are deemed away for mechanical signals. When a stress test with a one-off breach happens to be the most exterme shock even after disregarding the one-off breach, only that stress test (with a one-off breach) would be presented.

2/ The magnitude of shocks used for the commodity price shock stress test are based on the commodity prices outlook prepared by the IMF research department. 


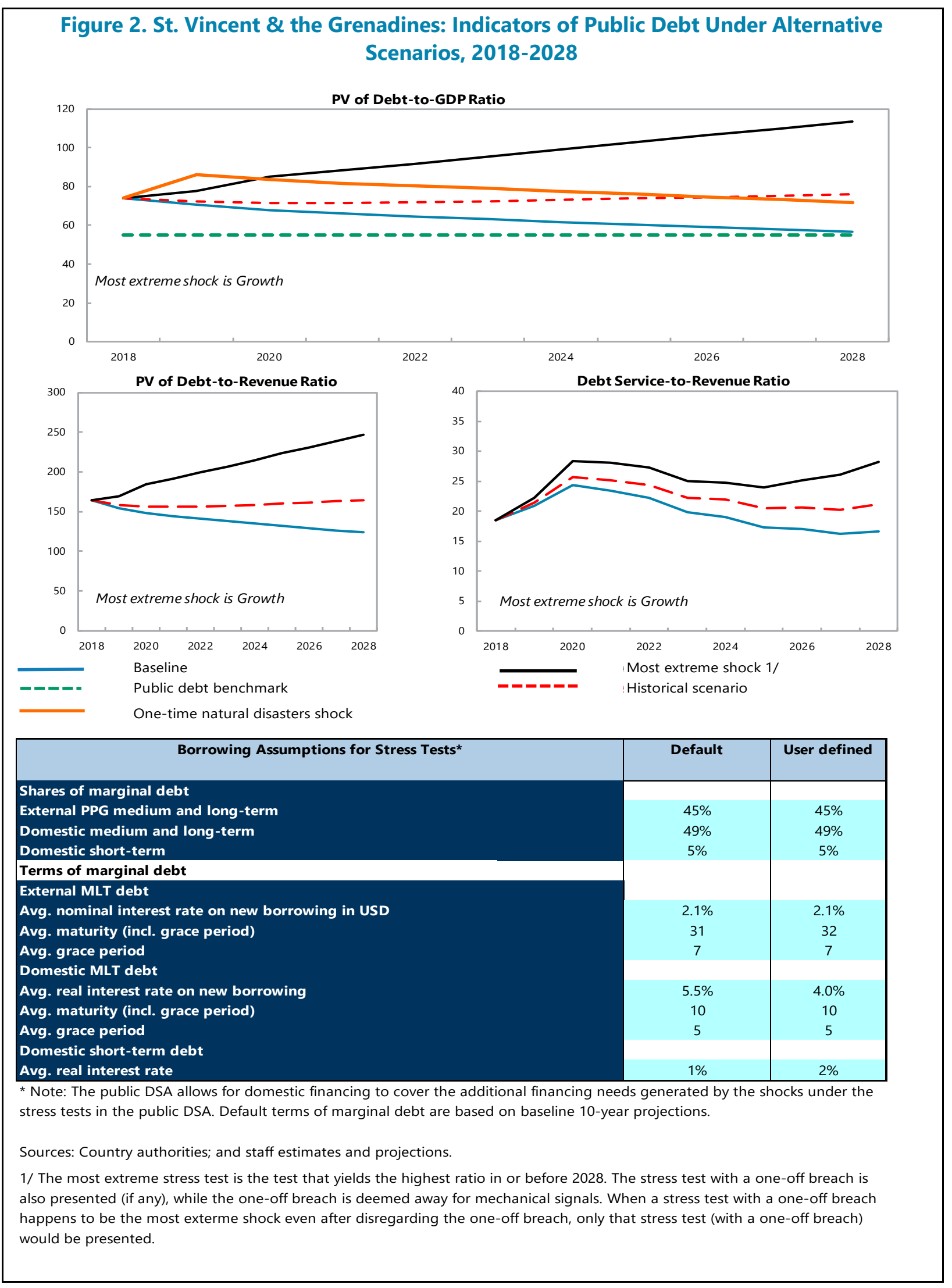


Figure 3. St. Vincent $\&$ the Grenadines: Drivers of Debt Dynamics - Baseline Scenario External Debt

Gross Nominal PPG External Debt (in percent of GDP; DSA vintages)

Debt-creating flows (percent of GDP)

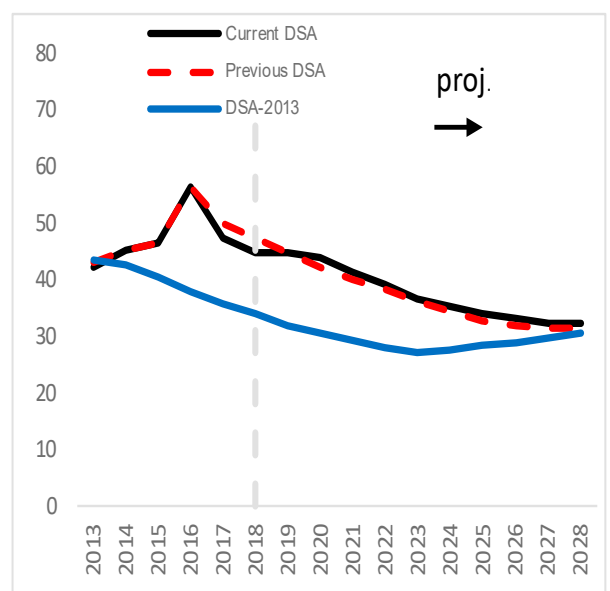

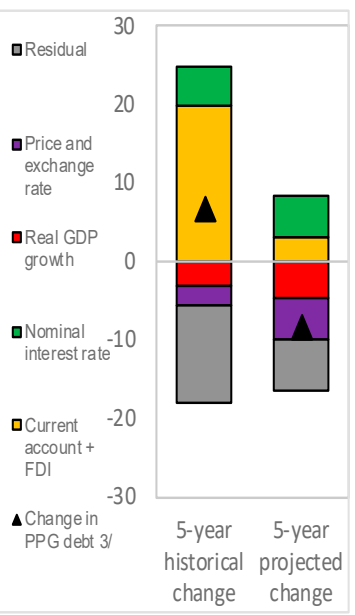

Unexpected Changes in Debt $1 /$ (past 5 years, percent of GDP)

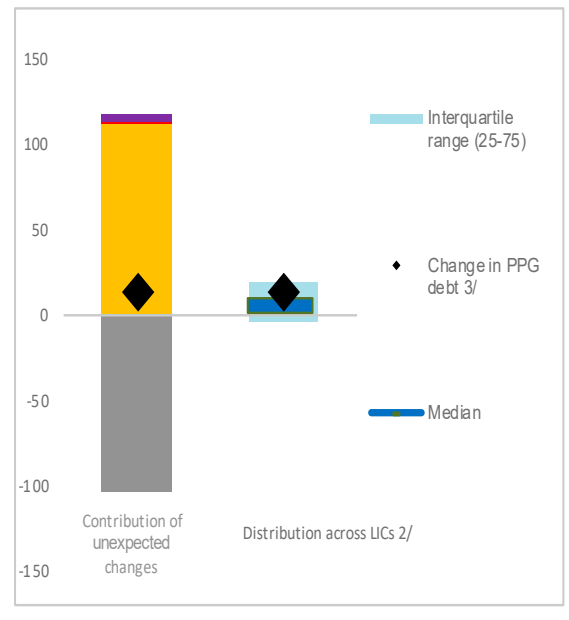

Public debt

Gross Nominal Public Debt (in percent of GDP; DSA vintages)

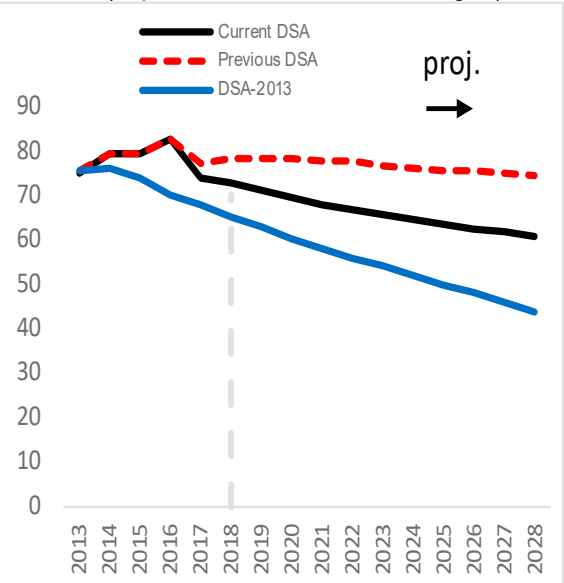

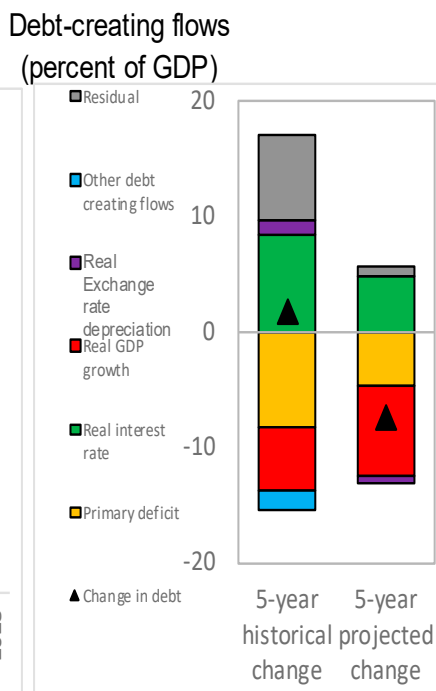

Unexpected Changes in Debt $1 /$ (past 5 years, percent of GDP)

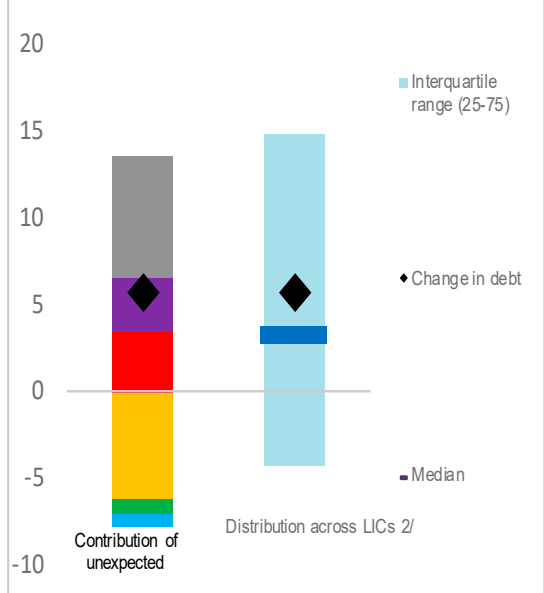

Sources: Country authorities; and staff estimates and projections. $1 /$ Difference betw een anticipated and actual contributions on debt ratios. 2/ Distribution across LICs for which LIC DSAs were produced.

3/ Given the relatively low private external debt for average low-income countries, a ppt change in PPG external debt should be largely explained by the drivers of the external debt dynamics equation. 
Figure 4. St. Vincent \& The Grenadines: Realism Tools

3-Year Adjustment in Primary Balance (Percentage points of GDP)

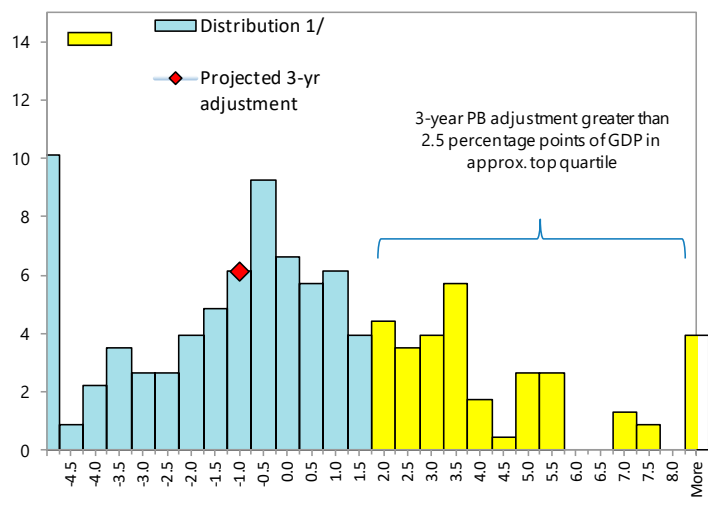

1/ Data cover Fund-supported programs for LICS (excluding emergency financing) approved since 1990. The size of 3-year adjustment from program inception is found on the horizontal axis; the percent of sample is found on the vertical axis

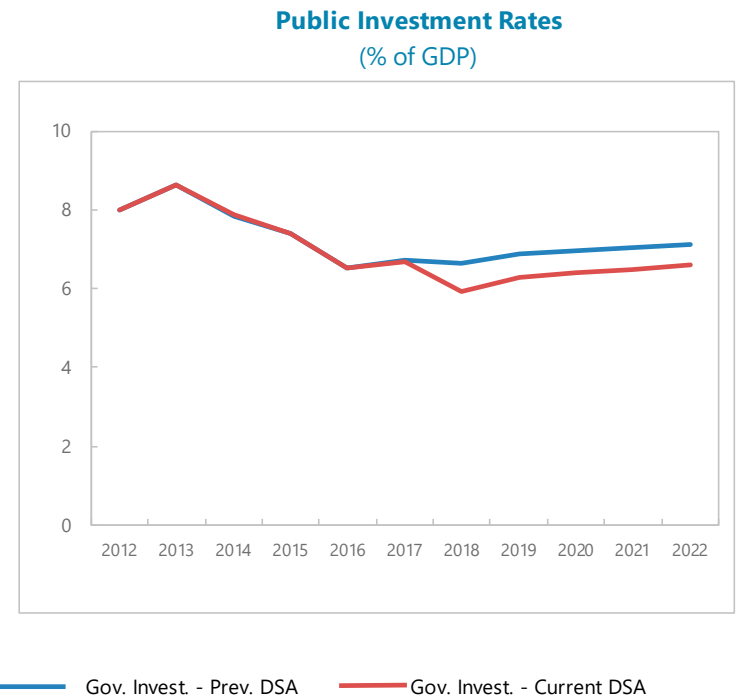

Fiscal Adjustment and Possible Growth Paths 1/

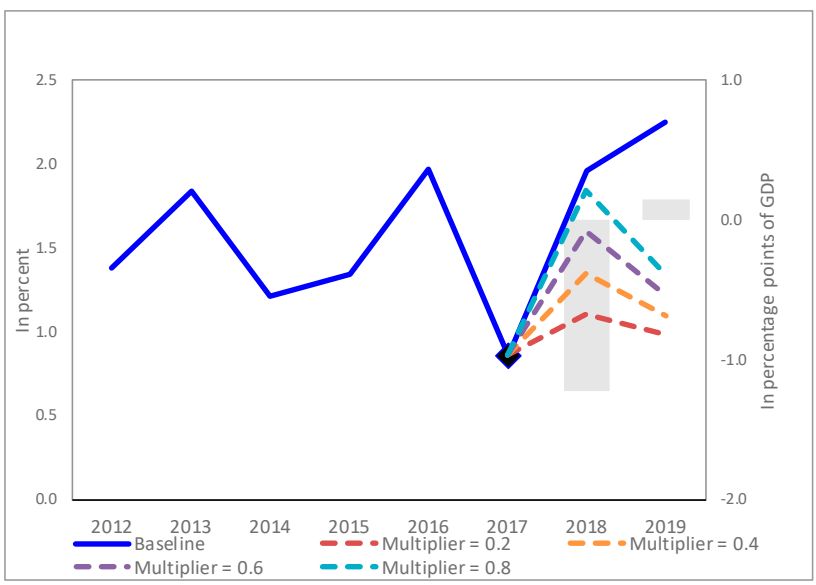

1/ Bars refer to annual projected fiscal adjustment (right-hand side scale) and lines show possible real GDP growth paths under different fiscal multipliers (left-hand side scale).

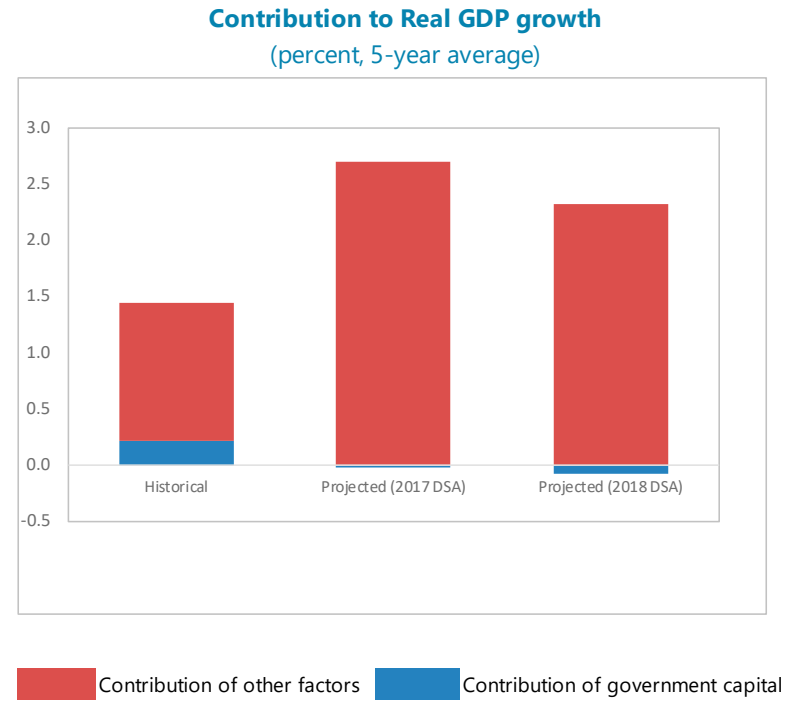




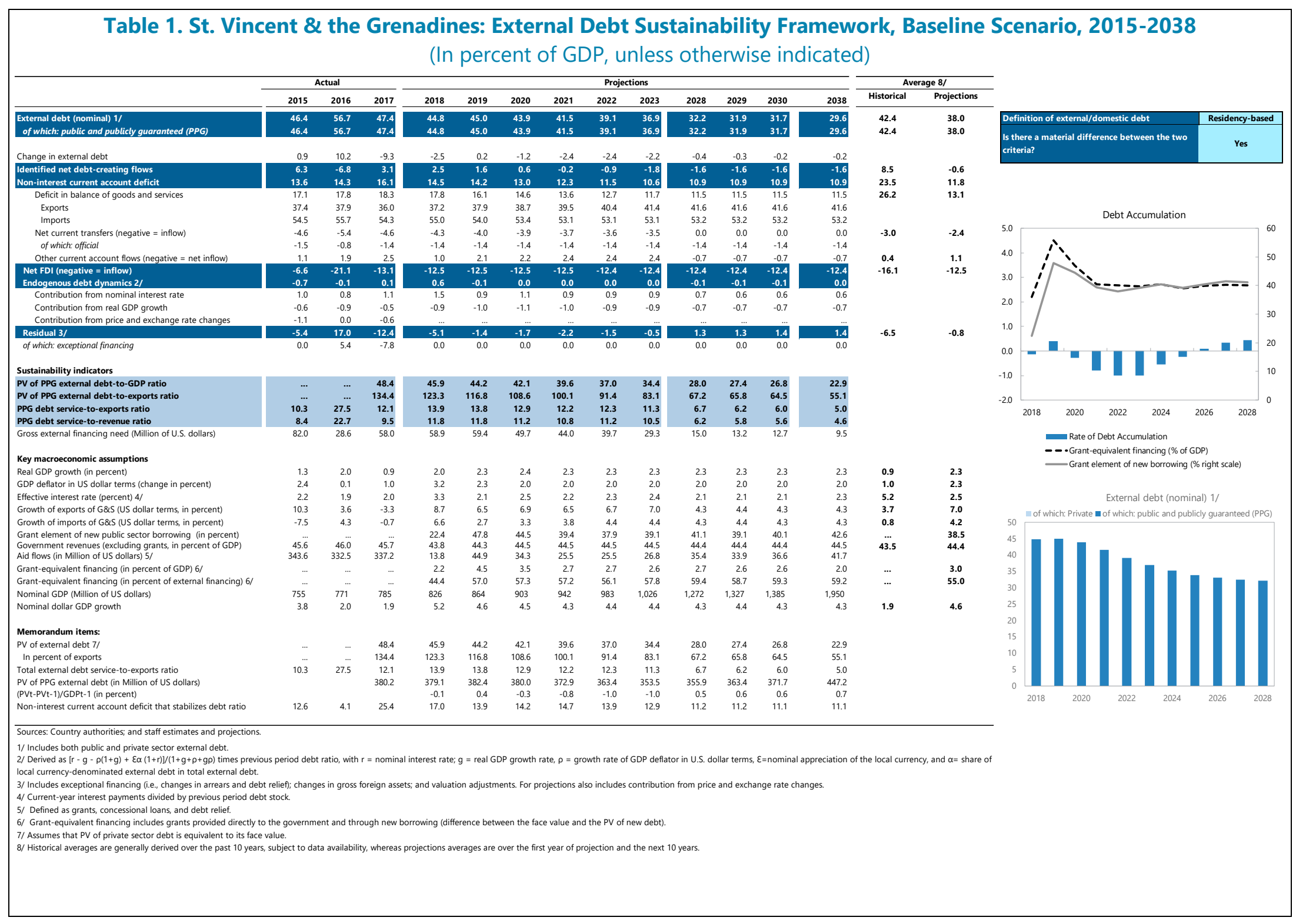


Table 2. St. Vincent \& the Grenadines: Public Sector Debt Sustainability Framework, Baseline Scenario, 2015-2038

(In percent of GDP, unless otherwise indicated)

\begin{tabular}{|c|c|c|c|c|c|c|c|c|c|c|c|c|c|c|c|}
\hline & \multicolumn{3}{|c|}{ Actual } & \multicolumn{10}{|c|}{ Projections } & \multicolumn{2}{|c|}{ Average $6 /$} \\
\hline & 2015 & 2016 & 2017 & 2018 & 2019 & 2020 & 2021 & 2022 & 2023 & 2028 & 2029 & 2030 & 2038 & Historical & Projections \\
\hline Public sector debt 1 / & 79.4 & 82.8 & 74.2 & 73.1 & 71.4 & 69.7 & 68.1 & 66.7 & 65.6 & 60.8 & 59.9 & 59.1 & 51.8 & 71.8 & 66.2 \\
\hline of which: external debt & 46.4 & 56.7 & 47.4 & 44.8 & 45.0 & 43.9 & 41.5 & 39.1 & 36.9 & 32.2 & 31.9 & 31.7 & 29.6 & 42.4 & 38.0 \\
\hline Change in public sector debt & -0.1 & 3.5 & -8.7 & -1.1 & -1.7 & -1.7 & -1.6 & -1.4 & -1.2 & -0.9 & -0.9 & -0.9 & -0.9 & & \\
\hline Identified debt-creating flows & -2.6 & 2.9 & -7.1 & -1.6 & -1.6 & -1.8 & -1.7 & -1.5 & -1.4 & -1.0 & -1.0 & -1.0 & -1.0 & 1.1 & -1.4 \\
\hline Primary deficit & -2.6 & -3.3 & -1.9 & -0.6 & .0 .8 & -1.0 & -1.0 & -1.1 & -1.2 & -1.3 & -1.3 & -1.3 & -1.3 & -0.8 & -1.1 \\
\hline Revenue and grants & 47.7 & 47.3 & 47.8 & 45.2 & 45.7 & 45.9 & 45.9 & 45.9 & 45.9 & 45.8 & 45.8 & 45.8 & 45.5 & 47.6 & 45.8 \\
\hline of which: grants & 2.0 & 1.2 & 2.1 & 1.4 & 1.4 & 1.4 & 1.4 & 1.4 & 1.4 & 1.4 & 1.4 & 1.4 & 1.0 & & \\
\hline Primary (noninteresst) expenditure & 45.1 & 44.0 & 45.9 & 44.6 & 44.9 & 44.9 & 44.9 & 44.8 & 44.7 & 44.5 & 44.5 & 44.5 & 44.2 & 46.8 & 44.7 \\
\hline Automatic debt dynamics & -0.1 & 0.8 & 1.0 & -1.0 & -0.9 & -0.7 & -0.6 & .0 .4 & -0.2 & 0.3 & 0.3 & 0.3 & 0.3 & & \\
\hline Contribution from interest rate//growth differential & 0.5 & 0.3 & 0.5 & -0.6 & -0.8 & -0.7 & -0.6 & -0.4 & -0.1 & 0.3 & 0.3 & 0.3 & 0.3 & & \\
\hline of which contribution from average real interest rate & 1.6 & 1.9 & 1.2 & 0.9 & 0.8 & 1.0 & 1.0 & 1.2 & 1.4 & 1.7 & 1.7 & 1.6 & 1.4 & & \\
\hline of which: contribution from real GDP growth & -1.1 & -1.5 & -0.7 & -1.4 & -1.6 & -1.7 & -1.6 & -1.5 & -1.5 & -1.4 & -1.4 & -1.3 & -1.2 & & \\
\hline Contribution from real exchange rate depreciation & -0.6 & 0.5 & 0.5 & & & & & & & & & & & & \\
\hline Other identified debt-creating flows & 0.0 & 5.4 & -6.2 & 0.0 & 0.0 & 0.0 & 0.0 & 0.0 & 0.0 & 0.0 & 0.0 & 0.0 & 0.0 & -0.4 & 0.0 \\
\hline Privatization receipts (negative) & 0.0 & 0.0 & 1.7 & 0.0 & 0.0 & 0.0 & 0.0 & 0.0 & 0.0 & 0.0 & 0.0 & 0.0 & 0.0 & & \\
\hline Recognition of contingent liabilities (e.g, bank recapitalization) & 0.0 & 0.0 & 0.0 & 0.0 & 0.0 & 0.0 & 0.0 & 0.0 & 0.0 & 0.0 & 0.0 & 0.0 & 0.0 & & \\
\hline Debt relief (HPC and other) & 0.0 & 5.4 & -7.8 & 0.0 & 0.0 & 0.0 & 0.0 & 0.0 & 0.0 & 0.0 & 0.0 & 0.0 & 0.0 & & \\
\hline Other debt creating or reducing flow (please specify) & 0.0 & 0.0 & 0.0 & 0.0 & 0.0 & 0.0 & 0.0 & 0.0 & 0.0 & 0.0 & 0.0 & 0.0 & 0.0 & & \\
\hline Residual & 2.6 & 0.5 & -1.6 & 0.1 & .0 .1 & 0.0 & 0.0 & 0.1 & 0.2 & 0.1 & 0.1 & 0.1 & 0.1 & 3.5 & 0.1 \\
\hline \multicolumn{16}{|l|}{ Sustainability indicators } \\
\hline PV of public debt-to-GDP ratio $2 /$ & .. & & 75.2 & 74.1 & 70.6 & 67.9 & 66.2 & 64.6 & 63.2 & 56.6 & 55.5 & 54.3 & 45.1 & & \\
\hline PV of public debt-to-revenue and grants ratio & .. & & 157.4 & 163.8 & 154.5 & 147.9 & 144.1 & 140.7 & 137.6 & 123.6 & 121.0 & 118.4 & 99.1 & & \\
\hline Debt service-to-revenue and grants ratio $3 /$ & 15.4 & 28.8 & 14.7 & 18.5 & 20.9 & 24.4 & 23.4 & 22.2 & 19.8 & 16.6 & 17.0 & 17.4 & 14.0 & & \\
\hline Gross financing need $4 /$ & 2.0 & 7.9 & 5.2 & 7.7 & 8.8 & 10.2 & 9.7 & 9.1 & 7.9 & 6.3 & 6.5 & 6.7 & 5.1 & & \\
\hline \multicolumn{16}{|l|}{ Key macroeconomic and fiscal assumptions } \\
\hline Real GDP growth (in percent) & 1.3 & 2.0 & 0.9 & 2.0 & 2.3 & 2.4 & 2.3 & 2.3 & 2.3 & 2.3 & 2.3 & 2.3 & 2.3 & 0.9 & 2.3 \\
\hline Average nominal interesst rate on extermal debt (in percent) & 2.2 & 1.9 & 2.0 & 3.3 & 2.1 & 2.5 & 2.2 & 2.3 & 2.4 & 2.1 & 2.1 & 2.1 & 2.3 & 5.2 & 2.3 \\
\hline Average real interest rate on domestic debt (in percent) & 3.2 & 4.8 & 4.3 & 1.7 & 3.0 & 2.9 & 3.3 & 4.0 & 4.6 & 5.6 & 5.6 & 5.7 & 5.8 & 6.0 & 4.1 \\
\hline Real exchange rate depreciation (in percent, + indicates depreciation) & -1.3 & 1.0 & 0.9 & ... & .... & ... & $\ldots$ & ... & $\ldots$ & $\ldots$ & ... & ... & $\ldots$ & 0.6 & ... \\
\hline Inflation rate (GDP deflator, in percent) & 2.4 & 0.1 & 1.0 & 3.2 & 2.3 & 2.0 & 2.0 & 2.0 & 2.0 & 2.0 & 2.0 & 2.0 & 2.0 & 1.0 & 2.1 \\
\hline Growth of real primary spending (deflated by GDP deffator, in percent) & -4.1 & -0.6 & 5.3 & -1.0 & 3.0 & 2.3 & 2.3 & 2.1 & 2.2 & 2.2 & 2.4 & 2.3 & 2.2 & 1.2 & 2.0 \\
\hline Primary deficit that stabilizes the debt-to-GDP ratio $5 /$ & -2.5 & -6.7 & 6.8 & 0.5 & 0.9 & 0.7 & 0.5 & 0.2 & 0.0 & -0.4 & -0.4 & -0.4 & -0.4 & -0.8 & 0.1 \\
\hline Vof contingent liabilities (not included in public sector debt) & 0.0 & 0.0 & 0.0 & 0.0 & 0.0 & 0.0 & 0.0 & 0.0 & 0.0 & 0.0 & 0.0 & 0.0 & 0.0 & & \\
\hline
\end{tabular}

Sources: Country authorities, and staff estimates and projections.

1/ Coverage of debt: The central government, government-guaranteed debt. Definition of external debt is Residency-based.

2/ The underlyng PV of external debt-to-GDP ratio under the public DSA differs from the extermal DSA with the size of dif

2The underying PV Gine

3/ Debt service is de da

4 Gross financing need is defined as hir primary defict plus debt service plus the stock of short-term debt at the end of the last period and other debt creating/reducing flows.

Id stabilizes the debt ratio only in the year in question.

6/ Historical averages are generally derived over the past 10 years, subject to data avalibbility, whereas projections averages are over the first year of projection and the next 10 years. 
Table 3. St. Vincent \& the Grenadines: Sensitivity Analysis for Key Indicators of Public and Publicly Guaranteed External Debt, 2018-2028

(In percent)

\begin{tabular}{|c|c|c|c|c|c|c|c|c|c|c|c|}
\hline & \multicolumn{11}{|c|}{ Projections 1/ } \\
\hline & 2018 & 2019 & 2020 & 2021 & 2022 & 2023 & 2024 & 2025 & 2026 & 2027 & 2028 \\
\hline \multicolumn{12}{|c|}{ PV of debt-to GDP ratio } \\
\hline Baseline & 46 & 44 & 42 & 40 & 37 & 34 & 32 & 31 & 30 & 29 & 28 \\
\hline $\begin{array}{l}\text { A. Alternative Scenarios } \\
\text { A1. Key variables at their historical averages in 2018-2038 2/ }\end{array}$ & 46 & 49 & 53 & 56 & 60 & 65 & 70 & 75 & 82 & 88 & 94 \\
\hline \multicolumn{12}{|l|}{ B. Bound Tests } \\
\hline B1. Real GDP growth & 46 & 47 & 48 & 45 & 42 & 39 & 37 & 35 & 34 & 33 & 32 \\
\hline B2. Primary balance & 46 & 45 & 43 & 41 & 38 & 36 & 34 & 32 & 31 & 30 & 30 \\
\hline B3. Exports & 46 & 50 & 57 & 54 & 51 & 48 & 46 & 44 & 43 & 42 & 41 \\
\hline B4. Other flows $3 /$ & 46 & 49 & 52 & 49 & 47 & 44 & 42 & 40 & 39 & 38 & 37 \\
\hline $\begin{array}{l}\text { B5. Depreciation } \\
\text { B. Combination of B1-B5 }\end{array}$ & 46 & 56 & 49 & 45 & 42 & 39 & 37 & 35 & 33 & 32 & 31 \\
\hline \multirow{2}{*}{\multicolumn{12}{|c|}{ c. Tailored Tests }} \\
\hline C1. Combined contingent liabilities & & & 48 & 46 & 43 & 41 & 39 & 38 & 37 & 37 & 36 \\
\hline C2. Natural disaster & 46 & 48 & 46 & 44 & 42 & 40 & 38 & 37 & 36 & 36 & 36 \\
\hline C3. Commodity price & n.a. & n.a. & n.a. & n.a. & n.a. & n.a. & n.a. & n.a. & n.a. & n.a. & n.a. \\
\hline C4. Market Financing & n.a. & n.a. & n.a. & n.a. & n.a. & n.a. & n.a. & n.a. & n.a. & n.a. & n.a. \\
\hline Threshold & 40 & 40 & 40 & 40 & 40 & 40 & 40 & 40 & 40 & 40 & 40 \\
\hline \multicolumn{12}{|c|}{ PV of debt-to-exports ratio } \\
\hline Baseline & 123 & 117 & 109 & 100 & 91 & 83 & 78 & 74 & 71 & 69 & 67 \\
\hline $\begin{array}{l}\text { A. Alternative Scenarios } \\
\text { A1. Key variables at their historical averages in 2018-2038 2/ }\end{array}$ & 123 & 130 & 136 & 142 & 148 & 156 & 168 & 181 & 196 & 211 & 226 \\
\hline \\
\hline B1. Real GDP growth & 123 & 117 & 109 & 100 & 91 & 83 & 78 & 74 & 71 & 69 & 67 \\
\hline B2. Primary balance & 123 & 118 & 112 & 103 & 95 & 86 & 81 & 78 & 75 & 73 & 71 \\
\hline B3. Exports & 123 & 151 & 195 & 182 & 169 & 156 & 149 & 143 & 139 & 135 & 130 \\
\hline $\begin{array}{l}\text { B4. Other flows 3/ } \\
\text { B5. Depreciation }\end{array}$ & 123 & 130 & 134 & 124 & 115 & 106 & 101 & 97 & 94 & 91 & 88 \\
\hline $\begin{array}{l}\text { B5. Depreciation } \\
\text { B6. Combination of B1-B5 }\end{array}$ & $\begin{array}{l}123 \\
123\end{array}$ & $\begin{array}{l}117 \\
145\end{array}$ & $\begin{array}{l}100 \\
127\end{array}$ & $\begin{array}{r}91 \\
144\end{array}$ & $\begin{array}{r}83 \\
133\end{array}$ & $\begin{array}{r}75 \\
122\end{array}$ & $\begin{array}{r}70 \\
116\end{array}$ & $\begin{array}{r}66 \\
111\end{array}$ & $\begin{array}{r}63 \\
107\end{array}$ & $\begin{array}{r}61 \\
104\end{array}$ & 60 \\
\hline \multicolumn{12}{|l|}{ 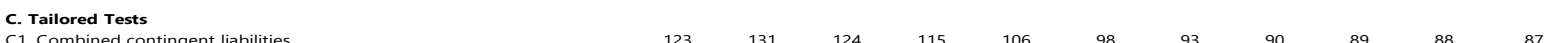 } \\
\hline c1. Combined contingent liabilities & 123 & 131 & 124 & 115 & 106 & 98 & 93 & 90 & 89 & 88 & 87 \\
\hline C2. Natural disaster & 123 & 129 & 122 & 114 & 105 & 97 & 93 & 90 & 88 & 88 & 87 \\
\hline C3. Commodity price & n.a. & n.a. & n.a. & n.a. & n.a. & n.a. & n.a. & n.a. & n.a. & n.a. & n.a. \\
\hline C4. Market Financing & n.a. & n.a. & n.a. & n.a. & n.a. & n.a. & n.a. & n.a. & n.a. & n.a. & n.a. \\
\hline Threshold & 180 & 180 & 180 & 180 & 180 & 180 & 180 & 180 & 180 & 180 & 180 \\
\hline \multicolumn{12}{|c|}{ Debt service-to-exports ratio } \\
\hline Baseline & 14 & 14 & 13 & 12 & 12 & 11 & 10 & 9 & 8 & 7 & 7 \\
\hline A. Alternative Scenarios & & & & & & & & & & & \\
\hline A1. Key variables at their historical averages in 2018-2038 2/ & 14 & 14 & 14 & 14 & 15 & 14 & 13 & 12 & 12 & 12 & 13 \\
\hline \multicolumn{12}{|l|}{ B. Bound Tests } \\
\hline $\begin{array}{l}\text { B1. Real GD growth } \\
\text { B2. Primary balance }\end{array}$ & 14 & 14 & 13 & 12 & 12 & 11 & 10 & 9 & 8 & 7 & 7 \\
\hline $\begin{array}{l}\text { B2. Primary balance } \\
\text { B3. Exports }\end{array}$ & $\begin{array}{l}14 \\
14\end{array}$ & $\begin{array}{l}14 \\
16\end{array}$ & $\begin{array}{l}13 \\
19\end{array}$ & $\begin{array}{l}12 \\
19\end{array}$ & ${ }_{19}^{12}$ & $\begin{array}{l}11 \\
17\end{array}$ & $\begin{array}{l}10 \\
15\end{array}$ & $\begin{array}{c}9 \\
13\end{array}$ & 8 & 72 & ${ }_{12}^{7}$ \\
\hline $\begin{array}{l}\text { B4. Other flows } 3 / \\
\text { But }\end{array}$ & 14 & 14 & 13 & 13 & 13 & 12 & 10 & $\begin{array}{l}9 \\
13\end{array}$ & 8 & 8 & 12 \\
\hline $\begin{array}{l}\text { B. } \\
\text { B5. Depreciation }\end{array}$ & 14 & 14 & 13 & 12 & 12 & 11 & 10 & 8 & 8 & 7 & $\begin{array}{l}8 \\
6\end{array}$ \\
\hline B6. Combination of B1-B5 & 14 & 15 & 16 & 16 & 16 & 14 & 13 & 11 & 10 & 10 & 10 \\
\hline \multicolumn{12}{|l|}{ c. Tailored Tests } \\
\hline c1. Combined contingent liabilities & 14 & 14 & 13 & 13 & 13 & 12 & 10 & 9 & 8 & 7 & \\
\hline C2. Natural disaster & 14 & 14 & 14 & 13 & 13 & 12 & 10 & 9 & 8 & 8 & 7 \\
\hline $\begin{array}{l}\text { C3. Commodity price } \\
\text { C4. Market Financing }\end{array}$ & n.a. & n.a. & $\begin{array}{c}\text { n.a. } \\
\text { n.a. }\end{array}$ & n.a. & $\begin{array}{c}\text { n.a. } \\
\text { n.a. }\end{array}$ & $\begin{array}{l}\text { n.a. } \\
\text { n.a. }\end{array}$ & n.a. & n.a. & n.a. & n.a. & n.a. \\
\hline Threshold & 15 & 15 & 15 & 15 & 15 & 15 & 15 & 15 & 15 & 15 & 15 \\
\hline \multicolumn{12}{|c|}{ Debt service-to-revenue ratio } \\
\hline Baseline & 12 & 12 & 11 & 11 & 11 & 10 & 9 & 8 & 7 & 7 & 6 \\
\hline A. Alternative Scenarios & & & & & & & & & & & \\
\hline A1. Key variables at their historical averages in 2018-2038 2/ & 12 & 12 & 12 & 12 & 13 & 13 & 12 & 12 & 11 & 12 & 12 \\
\hline \multicolumn{12}{|l|}{ B. Bound Tests } \\
\hline B1. Real GDP growth & 12 & 13 & 13 & 12 & 13 & 12 & 10 & 9 & 8 & 7 & 7 \\
\hline B2. Primary balance & 12 & 12 & 11 & 11 & 11 & 11 & 9 & 8 & 7 & 7 & 6 \\
\hline B3. Exports & 12 & 12 & 12 & 12 & 13 & 12 & 11 & 9 & 8 & 8 & 8 \\
\hline B4. Other flows $3 /$ & 12 & 12 & 12 & 11 & 12 & 11 & 10 & 9 & 8 & 8 & 8 \\
\hline B5. Depreciation & 12 & 15 & 14 & 13 & 14 & 13 & 11 & 10 & 9 & 8 & 7 \\
\hline B6. Combination of B1-B5 & 12 & 13 & 13 & 13 & 13 & 12 & 11 & 10 & 9 & 9 & 8 \\
\hline c. Tailored Tests & & & & & & & & & & & \\
\hline $\begin{array}{l}\text { C1. Combined contingent liabilities } \\
\text { c. Natural disaster }\end{array}$ & 12 & $\begin{array}{l}12 \\
12\end{array}$ & $\begin{array}{l}12 \\
11\end{array}$ & $\begin{array}{l}11 \\
11\end{array}$ & $\begin{array}{l}12 \\
11\end{array}$ & 11 & 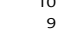 & $\begin{array}{l}8 \\
8\end{array}$ & $\begin{array}{r}8 \\
8\end{array}$ & $\begin{array}{l}7 \\
7\end{array}$ & $\begin{array}{l}7 \\
7\end{array}$ \\
\hline $\begin{array}{l}\text { C2. Natural disaster } \\
\text { C3. Commodity price }\end{array}$ & n.a. & n.a. & n.a. & n.a. & n.a. & n.a. & n.a. & n.a. & n.a. & п.а. & n.a. \\
\hline C4. Market Financing & n.a. & n.a. & n.a. & n.a. & n.a. & n.a. & n.a. & n.a. & n.a. & n.a. & n.a. \\
\hline Threshold & 18 & 18 & 18 & 18 & 18 & 18 & 18 & 18 & 18 & 18 & 18 \\
\hline
\end{tabular}




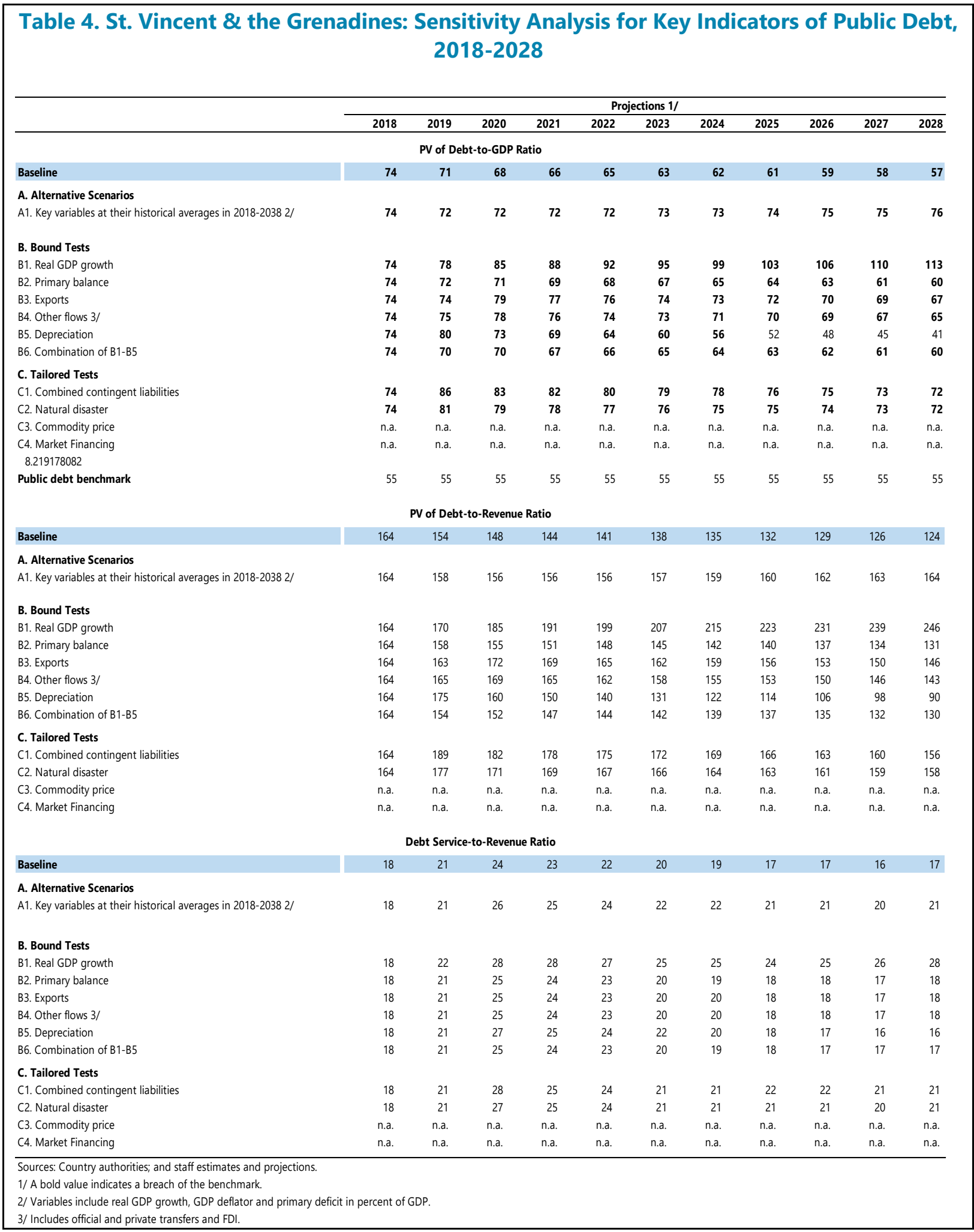




\section{INTERNATIONAL MONETARY FUND}

\section{ST. VINCENT AND THE GRENADINES}

STAFF REPORT FOR THE 2018 ARTICLE IV

February 13, 2019

CONSULTATION-SUPPLEMENTARY INFORMATION

Prepared By Western Hemisphere Department

1. This supplement provides information on the 2019 Budget released on

February 4, 2019. ${ }^{1}$ It is based on information that has become available since the staff report (SM/19/23) was issued on January 28, 2019 and does not alter the staff appraisal.

2. As in past years, the $\mathbf{2 0 1 9}$ budget plan is ambitious. The macroeconomic assumption underpinning budget estimates is largely consistent with staff's projection, with real GDP expected to grow by 2.3 percent in 2019 (the same as staff's projection). The budget, however, assumes a significant increase in capital spending, and as a result, the overall deficit is projected to widen to 7.3 percent of GDP in 2019, up from 2 percent of GDP in 2018 and way above staff's projection of 1.7 percent of GDP (Table 1).

- Total revenue and grants are projected at 30.3 percent of GDP in 2019, higher than staff's projection (28.2 percent of GDP), as the budget proposed new revenue measures, tax arrears collections, and higher grants. The proposed revenue enhancing measures include: (i) raising excise taxes on tobacco products, alcoholic beverages, and petroleum products; (ii) introducing a new excise tax on sweetened beverages; (iii) introducing new fees and export taxes on medical cannabis industry; and (iv) raising airport landing and parking fees.

- The budget expects capital expenditure at 9.5 percent of GDP, significantly higher than staff's projection (3.9 percent of GDP), assuming a large increase in donor financing. More than one-third of the capital budget has been allocated for projects to build resilience to natural disasters and climate change.

${ }^{1}$ The fiscal year starts on January 1. 
- On current expenditures, the total wage bill is expected at 13.7 percent of GDP, compared to staff's projection of 12.7 percent of GDP. Consistent with staff's projection, the budget assumes modest increases in salary-a retroactive one percent increase in salary from July 1, 2018 and additional 1.5 percent increase in 2019. In addition, the budget also assumes hiring of security officers, and healthcare workers. Other current expenditures, such as interest expense, and transfer and subsidies, are also higher than staff's projection.

\section{Staff Assessment}

\section{Over the past few years, the government always presented ambitious} budgets but implemented them prudently in light of available financing. Budgets typically projected sizable deficits, at around 7-8 percent of GDP, but the government managed to contain the overall deficit below 2 percent of GDP (Table 1 and see also paragraph 17 in the staff report). Capital budgets were under-executed, as securing external financing took longer than expected (while the authorities minimized recourse to domestic borrowing to finance capital projects). At the same time, current expenditure included fiscal buffers (e.g., vacancies in the wage bill), which helped the government contain the deficit.

\section{In his budget speech, Finance Minister Gonsalves reiterated the} government's commitment to ensuring fiscal sustainability and achieving the $\mathbf{6 0}$ percent debt to GDP target by $\mathbf{2 0 3 0}$. In order to achieve this goal, the government would need to keep the overall deficit below two percent of GDP in 2019, consistent with the government's track record. Current expenditure is likely to be higher than the staff report projection, but with new tax and non-tax measures and an execution rate of the capital budget and the wage bill broadly in line with the historical record, staff considers that it could be feasible to keep the overall deficit below two percent of GDP.

5. Nonetheless, the budget plan presents risks. If the government were to spend all allocations to current expenditure, departing from its past practices, the overall deficit could widen to 3 percent of GDP. In addition, the implementation of new revenue measures could be delayed. Furthermore, the medium-term budget framework does not fully incorporate the expected fiscal costs of natural disasters, as staff recommended. Given the downside risks, the authorities should continue to implement the budget prudently. Moreover, they should aim at bolstering fiscal buffers over the medium term, including by introducing additional fiscal measures to broaden the tax base as well as pursuing pension reform. The authorities should also step up efforts to accelerate ongoing fiscal reform initiatives, including improvement of fiscal forecasting, publication of the medium-term fiscal framework, enactment of the Tax Administration and Procedures Act, and legislation of the Contingency Funds' governance and operational framework. 
Table 1. St. Vincent and the Grenadines: Summary of Central Government Operations, 2016-2019 (In percent of GDP; unless otherwise specified)

\begin{tabular}{|c|c|c|c|c|c|c|c|c|}
\hline & \multicolumn{2}{|c|}{2016} & \multicolumn{2}{|c|}{2017} & \multicolumn{2}{|c|}{2018} & \multicolumn{2}{|c|}{2019} \\
\hline & Budget & Actual & Budget & Actual & Budget & $\begin{array}{r}\text { Staff } \\
\text { report }\end{array}$ & Budget & $\begin{array}{r}\text { Staff } \\
\text { report }\end{array}$ \\
\hline Total revenue and grants & 29.8 & 29.8 & 30.9 & 30.3 & 30.7 & 27.8 & 30.3 & 28.2 \\
\hline Current revenue & 27.1 & 28.5 & 27.9 & 27.9 & 27.9 & 26.3 & 28.1 & 26.7 \\
\hline Tax revenue & 24.3 & 25.5 & 24.9 & 25.7 & 24.4 & 24.1 & 25.1 & 24.4 \\
\hline Non-tax & 2.8 & 3.0 & 3.0 & 2.3 & 3.4 & 2.2 & 3.0 & 2.3 \\
\hline Capital Revenue & 0.0 & 0.1 & 0.0 & 0.3 & 0.3 & 0.0 & 0.1 & 0.1 \\
\hline Grants & 2.6 & 1.2 & 3.0 & 2.1 & 2.6 & 1.4 & 2.1 & 1.4 \\
\hline Total expenditure and net lending & 37.8 & 28.7 & 39.2 & 30.8 & 37.4 & 29.8 & 37.6 & 29.9 \\
\hline Current & 28.3 & 24.9 & 28.4 & 26.7 & 27.7 & 26.2 & 28.1 & 26.0 \\
\hline Wages and salaries $1 /$ & 14.1 & 13.2 & 14.0 & 13.3 & 13.6 & 12.8 & 13.7 & 12.7 \\
\hline Interest & 2.5 & 2.1 & 2.6 & 2.3 & 2.7 & 2.6 & 2.9 & 2.4 \\
\hline Transfers and subsidies & 8.0 & 6.4 & 8.0 & 7.4 & 7.7 & 7.4 & 7.6 & 7.3 \\
\hline Goods and services & 3.6 & 3.3 & 3.7 & 3.7 & 3.7 & 3.4 & 4.0 & 3.6 \\
\hline Capital expenditure & 9.5 & 3.8 & 10.8 & 4.1 & 9.7 & 3.6 & 9.5 & 3.9 \\
\hline Overall balance & -8.0 & 1.1 & -8.3 & -0.5 & -6.7 & -2.0 & -7.3 & -1.7 \\
\hline Primary balance & -5.5 & 3.2 & -5.6 & 1.9 & -4.0 & 0.6 & -4.5 & 0.8 \\
\hline \multicolumn{9}{|l|}{ Memorandum item } \\
\hline Nominal GDP (market prices, EC\$ millions) 2/ & 2,081 & 2,081 & 2,120 & 2,120 & 2,231 & 2,231 & 2,334 & 2,334 \\
\hline
\end{tabular}

Sources: Ministry of Finance and Planning; and Fund staff estimates and projections.

1/ Wages and salaries including social security contributions, commissions, rewards, allowances, and incentives.

2/ GDP numbers in 2018 and 2019 are staff's estimate and projection, respectively. 


\author{
Statement by Ms. Louise Levonian, Executive Director, and Mr. Courtney \\ Williams, Senior Advisor to Executive Director on St. Vincent and the Grenadines \\ February 15, 2019
}

Our St. Vincent and the Grenadines (SVG) authorities highly appreciate the Fund's continued support and thank staff for the productive engagement during the Article IV consultations. They welcome the report, value staff's advice, and appreciate the report's acknowledgement of noteworthy macroeconomic progress. That said, our authorities are of the view that the report could better highlight advances on structural reforms.

The government remains focused on transforming SVG into a more vibrant, competitive, and inclusive economy. In line with this objective, SVG will accelerate policies geared toward furthering fiscal consolidation, enhancing the business environment, and strengthening resilience to natural disasters and climate change. These efforts, to be accompanied by measures to bolster social protection, will be instrumental in diversifying the economic base and stimulating private-sector led job-rich growth.

\title{
Recent Economic Developments
}

Economic expansion continues to strengthen while inflation remains benign. Preliminary estimates point to an acceleration of growth in 2018 to 2.5 percent from an average annual growth rate of 0.8 percent over the previous three years. Growth was hampered in 2016 and 2017 by the closure of the island's largest hotel and adverse weather conditions - flooding and landslides. Underpinning the growth uptick was the strong performance of tourism and construction. The opening of the new Argyle International Airport in early 2017 - an important pillar of the economic transformation process - buoyed tourism flows. SVG also benefited from increased demand for construction materials by Dominica following Hurricane Maria in 2017. At the same time, higher commodity and fuel prices led to an uptick in average inflation to just over 2 percent, following years of deflation.

Fiscal performance supported debt reduction objectives. The primary balance remained in surplus and contributed to a reduction in public debt to an estimated 73 percent of GDP in 2018 from over 82 percent in 2016. Revenue collections were behind budget, however, restraint in current spending and under-execution of capital programs resulted in an estimated overall fiscal deficit of 2.0 percent of GDP, compared to the budgeted 6.7 percent. 
Our authorities have advanced efforts to safeguard the stability of the financial sector. The sector remains broadly stable, but concerns linger about the loss of correspondent banking relationships (CBR), and de-risking more broadly. Notable progress in addressing AML/CFT deficiencies included amendments to several pieces of legislation and ongoing work on the National Risk Assessment (NRA). Of note, banks maintained high capital ratios while NPLs continued to decline and remained below the ECCU average.

\section{Economic Outlook \& Policies}

Steady and sustained implementation of credible policies remain key to strengthening, diversifying, and inclusively growing the SVG economy. While our authorities consider the outlook to be favorable, they remain fully aware that SVG, like many small island states, is highly susceptible to external shocks and adverse weather conditions. Building on steps already taken to improve its ability to respond to natural disasters, enhance human capital, and upgrade the physical and legislative infrastructure, the government will continue to advance a multi-pronged approach geared toward tackling vulnerabilities and transforming the economy.

The growth outlook is positive but there are downside risks. Real economic output is estimated to grow at 2.5 percent for 2018 and slightly higher over the medium term. Our authorities are nevertheless mindful of inherent risks from, inter alia, natural disasters, higher commodity prices, and weaker than expected global growth. The new climate-resilient international airport has improved connectivity and is expected to further boost tourist arrivals and seafood exports, with positive spillovers to connected sectors. Significant private investment to boost hotel room stock, as well as large public infrastructure projects, including those related to climate change and upgrading of the road network, geothermal energy, and port facilities provide the impetus for stronger growth.

\section{Fiscal Policy and Debt Management}

Fiscal policy will be shrewdly managed within the context of achieving the ECCU debt/GDP target of 60 percent by 2030 while supporting economic transformation. Our authorities agree in principle with staff's suggestion that accelerating fiscal consolidation will help to build buffers and reduce debt faster. However, this must be carefully balanced against the need to stimulate higher levels of growth and reduce high unemployment and poverty. In this regard, the 2019 budget forecasts a significant scaling up of capital expenditure. While this may cause the public debt to rise in the near term, the magnitude of increase would be moderated by faster growth and planned measures to boost revenue and contain current spending. The medium-term fiscal framework (MTFF) that informs the 2019 budget contains critical growth-friendly projects to be completed over the next two to three years. These include climate change-related projects that account for close to 40 percent of the capital budget, port modernization, and the geothermal plant, which on completion is expected to raise renewable energy usage to about 80 percent. Given the expected growth dividend alongside improved fiscal performance, our authorities are confident of remaining on course with the 2030 Debt/GDP target. 
Efforts will be stepped up to drive ongoing and planned fiscal reforms. The government's MTFF that underpinned this year's budget will be tabled in Parliament shortly. Going forward, the MTFF will be the cornerstone of future budgets. Measures to mobilize revenue are underway with plans to table the Tax Administration and Procedures Act in Parliament during the first quarter of 2019. The proposed changes will considerably close tax loopholes currently being exploited by corporates. Additionally, regulations will be promulgated to enhance operations and oversight of SOEs. Pension reform also forms a critical part of our authorities' program to contain current spending and discussions surrounding the design of a scheme are advancing.

\section{Financial Sector}

Actions to bolster financial system stability will intensify. Recent legislative enhancements have yielded a more robust AML/CFT regime. Nevertheless, our authorities will continue to work assiduously to ensure that the framework remains compliant with international standards and commit to completing the NRA by September this year. Following good progress in the stress testing of credit unions, the FSA will extend the exercise to the insurance sector. Our authorities are seized with the urgency of strengthening vigilance over the financial sector. In this regard, an adequately-resourced FSA remains a priority, and the government will enact legislation to bolster the FSA's enforcement powers. The government also continues to collaborate with the ECCB as part of an ongoing regional initiative to establish a modern credit reporting system. Our authorities acknowledge that there are scale economies from consolidation and, in this context, they will pursue strategies for amalgamating small local banks, including within the wider ECCU region.

\section{Structural Reforms}

Our authorities will accelerate implementation of reforms to expand growth potential. SVG has implemented some key reforms to strengthen fiscal management and enhance financial sector supervision, but a lot more is required for the country to take advantage of existing and potential opportunities. The new international airport with direct flights to main source markets has expanded tourism prospects. To capitalize on these opportunities, our authorities will forge closer linkages between tourism and other sectors, particularly agriculture. The geothermal plant promises lower electricity costs, which will enhance competitiveness. However, the quality of the physical and human infrastructure needs to keep pace with these developments. Against this backdrop, the government is taking decisive steps to accelerate project implementation with donor support. They will also move with dispatch to review the current procedural and legislative framework for investment with a view to simplifying the requirements. To ensure that the workforce is in sync with labor market demands, the government will provide additional resources to expand skills training in the technical and vocational areas. These activities are all crucial to stimulate private sector investment and generate jobs in various sectors of the economy.

Social protection remains a priority for the government. Broad-based support is integral to the success of the reform agenda. To ensure that all Vincentians benefit from the economic 
transformation, our authorities endeavor to protect social spending, including intensifying targeted support toward gender development, childcare, and youth empowerment.

\section{Strengthening Resilience to Natural Disasters and Climate Change}

Our authorities consider natural disasters and climate change to be their most formidable near-and long-term threats. They appreciate staff's tailored stress tests incorporating natural disasters into the DSA. Strengthening resilience will provide important growth and fiscal dividends. The establishment of a Contingencies Fund in 2017, strictly for funding expenses related to natural disasters, was an important step in this regard. Moreover, the 2019 budget includes a sizeable allocation to climate-related projects, including allocations to the Natural Disaster Management and the Regional Disaster Vulnerability Reduction projects amounting to about 2 percent of GDP. This is further demonstration of the significance that the government attaches to resilience building. 